\title{
Results of Archaeological Survey and Limited Archival Research of Fairfield Lake State Park, Freestone County, Texas
}

Julian A. Sitters

Archeology Division, Texas Historical Commission

Jon C. Lohse

Center for Archaeological Studies

David M. Yelacic

Sarah Scogin

Center for Archaeological Studies

Follow this and additional works at: https://scholarworks.sfasu.edu/ita

Part of the American Material Culture Commons, Archaeological Anthropology Commons, Environmental Studies Commons, Other American Studies Commons, Other Arts and Humanities Commons, Other History of Art, Architecture, and Archaeology Commons, and the United States History Commons

Tell us how this article helped you.

This Article is brought to you for free and open access by the Center for Regional Heritage Research at SFA ScholarWorks. It has been accepted for inclusion in Index of Texas Archaeology: Open Access Gray Literature from the Lone Star State by an authorized editor of SFA ScholarWorks. For more information, please contact cdsscholarworks@sfasu.edu. 
Results of Archaeological Survey and Limited Archival Research of Fairfield Lake State Park, Freestone County, Texas

\section{Creative Commons License}

(c) (1) (8)

This work is licensed under a Creative Commons Attribution-NonCommercial 4.0 International License 
Results of Archaeological Survey and Limited Archival Research of Fairfield Lake State Park, Freestone County, Texas

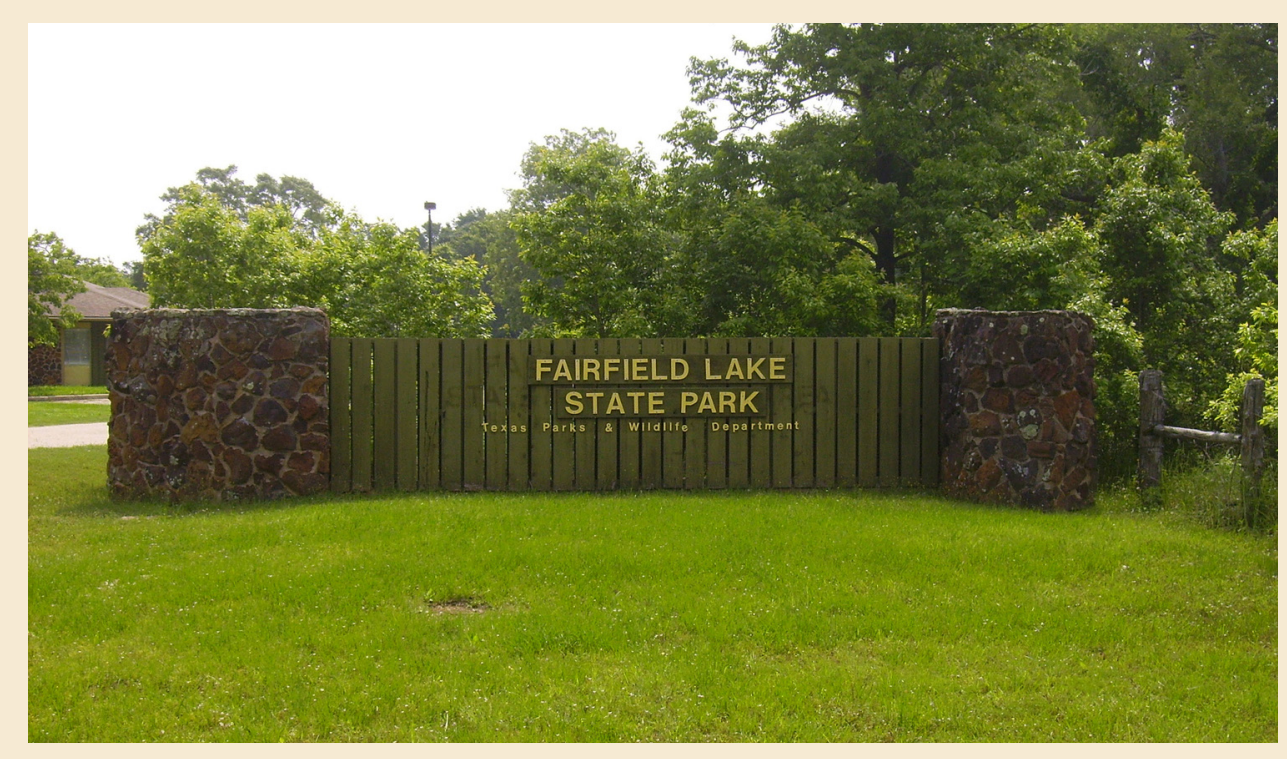

By

Julian A. Sitters, Jon C. Lohse, David M. Yelacic, and Sarah Scogin

Principal Investigator: Jon C. Lohse

Texas Antiquities Permit No. 5203

TEXAS PARKS AND WILDLIFE

Archaeological Studies Report No. 17

4200 Smith School Road, Austin, Texas 78744

Center for Archaeological Studies Texas State University-San Marcos 


\title{
Results of Archaeological Survey and Limited Archival Research of Fairfield Lake State Park, Freestone County, Texas
}

\author{
by \\ Julian A. Sitters, Jon C. Lohse, David M. Yelacic, and Sarah Scogin
}

Principal Investigator: Jon C. Lohse

Archaeological Studies Report No. 17

Center for Archaeological Studies

Texas State University-San Marcos

2009 
The following information is provided in accordance with the General Rules of Practice and Procedures, Title 13, Chapter 26, Texas Administrative Code:

1. Type of investigation: Survey of cultural resources.

2. Project name: Archaeological Survey and Limited Archival Research of Fairfield Lake State Park, Freestone County, Texas.

3. County: Freestone

4. Principal Investigators: Jon C. Lohse

5. Name and location of sponsoring agency: Texas Parks and Wildlife Department, 4200 Smith School Road, Austin, Texas, 78744.

6. Published by the Center for Archaeological Studies, Texas State University-San Marcos, 601 University Drive, San Marcos, Texas, 78666-4616 (2009)

Texas State University-San Marcos is a member of the Texas State University System Copyright (C) 2009 by the Center for Archaeological Studies at Texas State University-San Marcos

All rights reserved.

No part of this book may be reproduced or utilized in any form or by any means, electronic or mechanical, including photocopying, recording,

or by any information storage and retrieval system

without permission in writing.

For further information on this and other publications by

the Center for Archaeological Studies, please contact:

Center for Archaeological Studies

Texas State University-San Marcos

601 University Drive

San Marcos, TX 78666-4616

www.txstate.edu/anthropology/cas/

Editor: Carole Leezer

Cover Photograph: Fairfield Lake State Park entrance sign

Printed in the United States of America

by

Center for Archaeological Studies, Texas State University-San Marcos 


\section{Management Summary}

Fairfield Lake State Park occupies 1,460 acres in Freestone County, approximately five miles northeast of Fairfield, Texas. The land was leased by Texas Parks and Wildlife Department (TPWD) from Luminate Power (formerly Texas Utilities) in the 1970s. Under provisions of the Texas Antiquities Code, TPWD is responsible for managing cultural resources on park land. In an effort to compile an inventory of sites in the park, a cultural resource survey was conducted by Stephen F. Austin State University (SFA) in 1996 under Texas Antiquities Permit No. 1698, granted to Dr. James E. Corbin. The SFA team recorded or revisited a total of 34 sites in the park's 1,460 acres, though never completed a final report. In 2008, TPWD contracted the Center for Archaeological Studies at Texas State University-San Marcos (CAS) to complete this earlier project. Working under contract with TPWD and the reactivated Permit No. 1698, CAS revisited and reassessed the 34 recorded sites, recorded an additional site, 41FT630 - an abandoned historic cemetery - and finalized the analysis and curation of all documents and artifacts recovered in 1996 and 2008. After the completion of the 2008 project, it was unclear whether or not the entire 1,460 acres of the park had been included in the survey, and whether the list of 35 sites represented all of the cultural resources that were present in the park.

Following the 2008 reassessment, TPWD contracted CAS to carry out a systematic survey of the 1,460-acre park, excluding previously recorded sites, inundated terrain, and areas of modern disturbance that resulted from park infrastructure developments. The purpose of the survey was to ensure a complete inventory of cultural resources within the park. The effort included pedestrian survey and excavation of 215 shovel tests, as well as archival research to identify historic structures that may have once been present, but that were now razed and that could be considered potential sites. An additional element of this project involved some archival research to determine whether 41FT630, the abandoned cemetery, had ever been platted at the Freestone County Clerk's office, as required under Chapter 711 of the State of Texas Health and Safety Code. Archival and field work was performed in April and May of 2009 by Julian A. Sitters, Project Archaeologist, Sarah Scogin, CAS Staff Archaeologist, and Jon C. Lohse, who served as Principal Investigator. No new sites were recorded during this project, and CAS found no indication that 41FT630 has ever been platted. Available records indicate that it likely represents a freedmen descendant community cemetery, containing individuals who were probably slaves or immediate descendants of freed slaves. CAS recommends archaeological survey and oral interviews concerning this site before it is legally platted at the County Clerk's office in Fairfield, Texas. 


\section{Table of Contents}

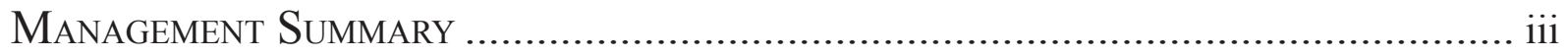

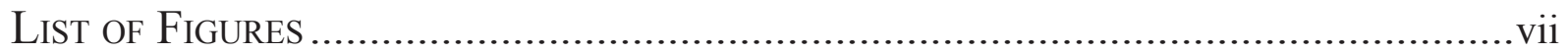

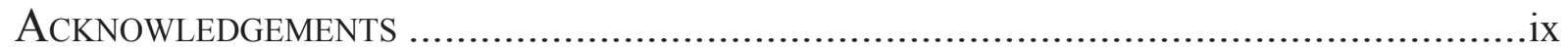

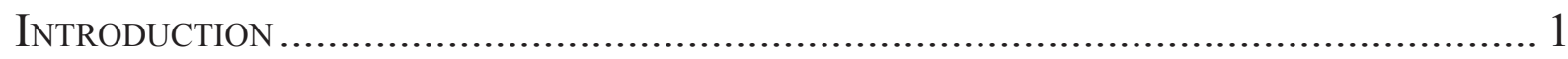

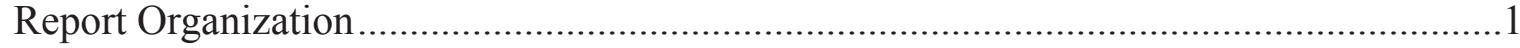

Archaeological Site Evaluation Criteria ………………..................................................

Project Setting and Cultural Chronology ........................................................ 5

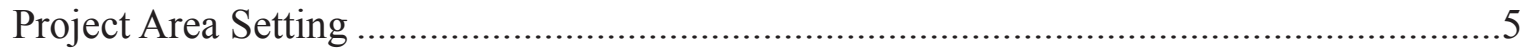

Cultural Chronology for Northeast Central Texas ...........................................................

Previous Archaeological Investigations ............................................................................13

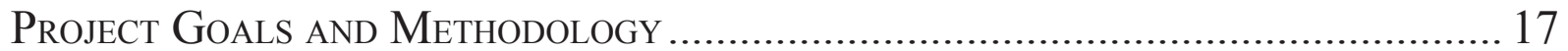

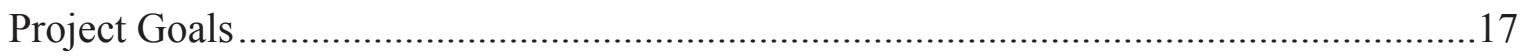

Archival Methods..................................................................................................17

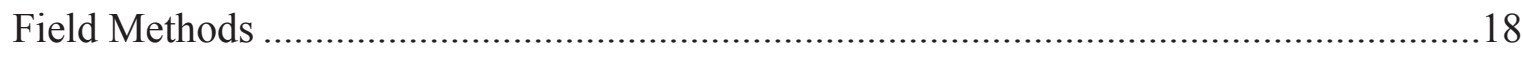

Field Documentation and Artifact Collection ……....................................................18

Laboratory Methods and Curation ..................................................................................19

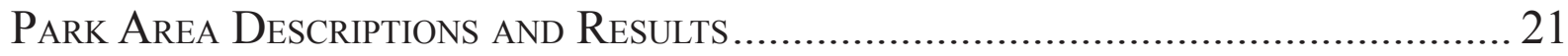

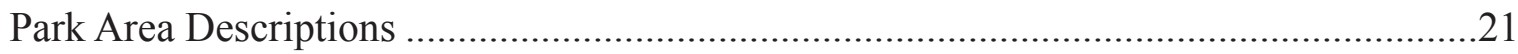

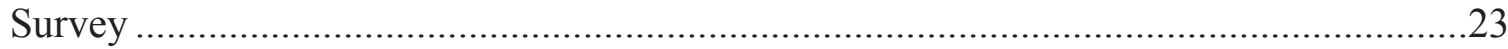

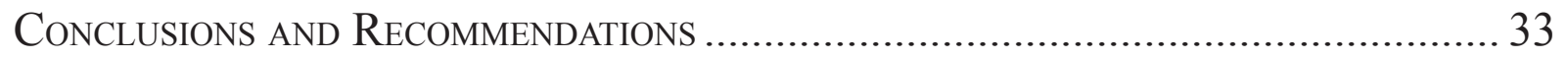

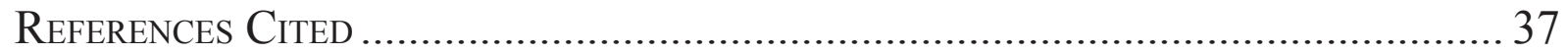

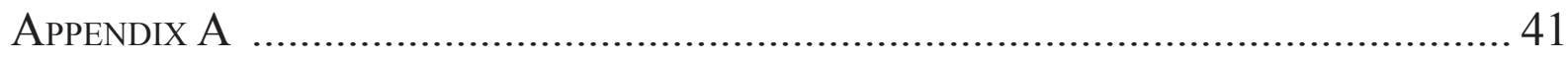

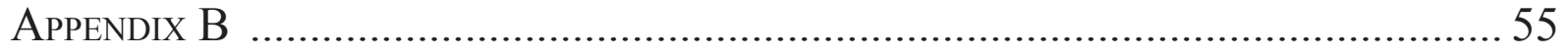




\section{List Of Figures}

Figure 1-1. Location of Fairfield Lake State Park and survey area of the 1996 project plotted on the Young 7.5' United States Geologic Survey opographic sheet. Inset map shows location of Freestone County

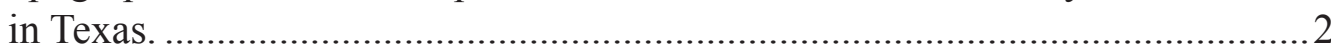

Figure 2-1. Level III Ecoregions map of Texas with Freestone County outlined

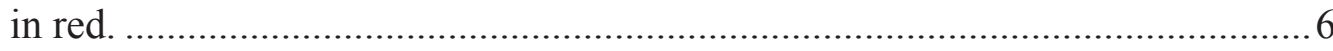

Figure 2-2. Soils found across Fairfield Lake State Park, bounded in yellow (after Janak and Griffin 2002:Plate 19)...................................................... 7

Figure 4-1. Pond located in the southwestern portion of the park, northeast of

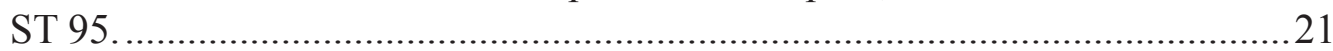

Figure 4-2. Possible agricultural field located in the southwestern portion of

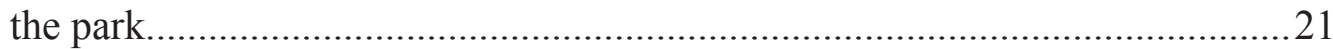

Figure 4-3. ST 100. Note the pooling of water at the bottom of the excavated shovel test.................................................................................... 22

Figure 4-4. Possible agricultural field located in the southern portion of the park, southwest of the park headquarters ........................................................22

Figure 4-5. ST 210 located in the eastern portion of the park. Note the clay

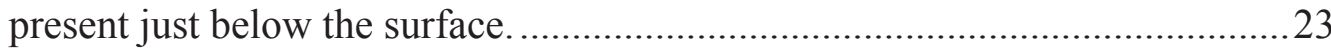

Figure 4-6. Terrain common in the northwestern portion of the park...............................23

Figure 4-7. Possible agricultural field located in the northwestern portion of

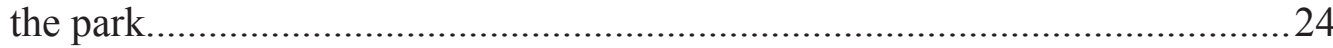

Figure 4-8. Terrain common in the northern portion of the park......................................24

Figure 4-9. $\quad$ ST 210 located in the northern portion of the park. Note the clay

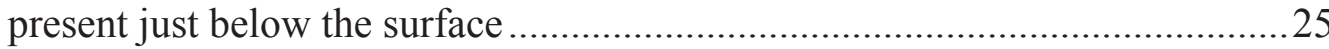

Figure 4-10. Barbed wire: (A) Encased within the tree trunk; (B) Attached to a wooden post using a U-shaped staple ..................................................... 25

Figure 4-11. Modern trash: (A) Beer cans; (B) Park maintenance debris. ..........................26

Figure 4-12. Historic metal objects confiscated by TPWD: (A) Historic hoe head;

(B) Unknown historic metal object. ......................................................26

Figure 4-13. Cluster of bricks located in the Springfield Camping area. ............................26

Figure 4-14. Possible historic road located northwest of the maintenance barn; photographed facing east.

Figure 4-15. Glass bottles located northwest of the maintenance barn:

(A) Incomplete glass cup, date unknown; (B) Complete glass bottle (1932 to 1953 or later); (C) Complete glass bottle (1911-or later) ..................27

Figure 4-16. Iron ore sphere observed in ST 42 ........................................................ 27

Figure 4-17. Wooden board fastened to a tree near ST 109.........................................28

Figure 4-18. Abandoned Buick vehicle. ...................................................................28

Figure 4-19. Possible agricultural field located in the northwestern portion of the park near the primitive camping area.....................................................2 28

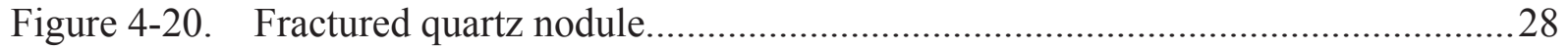


Figure 4-21. ST 196 located in the northwestern portion of the park. Note the presence of clay at the surface. .............................................................2. 29

Figure 4-22. Metal buckets located 68 meters downhill from site 41FT470......................29

Figure 4-23. ST 204 located in the northwestern portion of the park. Note the

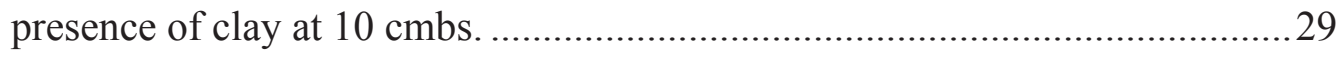

Figure 4-24. Modern park debris: (A) Concrete pipes; (B) Wooden posts........................... 30

Figure 4-25. Possible large abandoned agricultural field............................................... 30

Figure 4-26. Inundated area located to the northeast of the large abandoned

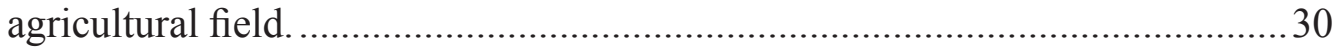

Figure 4-27. Isolated finds: (A) Bound barbed wire; (B) Brick scatter ............................. 31

Figure 4-28. Possible historic road; photographed facing north....................................... 31 


\section{ACKNOWLedgements}

The Center for Archaeological Studies would like to thank Dawn Ramsey and Todd McMakin, Cultural Resource Coordinators for Region III of Texas Parks and Wildlife Department, and Michael Strutt, Director of Cultural Resources, who made this project possible. We would also like to express our appreciation for Park Superintendent Officer Mike Kleinert and his staff for their assistance with facilitating park access and fieldwork coordination. The fieldwork described in this report was conducted by Julian A. Sitters, who served as Project Archaeologist, and Sarah Scogin, CAS Staff Archaeologist. Dr. Jon Lohse served as the Principal Investigator for the CAS investigations, and contributed to the fieldwork as well. Maps and illustrations for this project were prepared by David Yelacic. Photographs and documents were prepared for curation by Sarah Scogin. Carole Leezer assisted with the assembly and editing of this report. 


\section{Chapter 1}

\section{INTRODUCTION}

by Julian A. Sitters and Jon C. Lohse

This report presents the results of a cultural resource survey and archival investigation conducted at Fairfield Lake State Park (park), in Freestone County, Texas (Figure 1-1). Previous investigations of the park were performed in 1996 by students of Stephen F. Austin University (SFA), under the direction of Dr. James E. Corbin. Unfortunately, Dr. Corbin passed away before that project and its report were ever completed. In 2008, Texas Parks and Wildlife Department (TPWD) contracted with the Center for Archaeological Studies (CAS) at Texas State University-San Marcos to compile notes, field and artifact photographs, and site forms that were generated during that survey in order to complete the SFA project. This task involved revisiting each of the 34 sites that had been recorded in the park. A 35th site, 41FT630, an abandoned historic cemetery, was recorded in the process (Yelacic et al. 2008). Because of the status of field records from the SFA project, it was not possible to know for certain whether those students systematically covered the entire park area, or whether they preferentially focused on what may have been perceived as high probability areas. Consequently, it was not known with confidence whether the inventory of 35 documented sites in the park could be viewed as a complete record of cultural resources that were present, and for which TPWD personnel were responsible under the Texas Antiquities Code. Following the 2008 CAS survey (Yelacic et al. 2008), TPWD contracted CAS to carry out a systematic and complete survey of the 1,460acre park (excluding previously recorded sites, inundated and steeply sloping terrain, and areas of disturbance and construction) in order to provide a verifiably complete inventory of historic and prehistoric sites. The purpose of this work, in conjunction with the previous survey, is to assist TPWD in developing a site management plan in the event of future developments within the park boundaries. Additionally, recommendations concerning site 41FT630 are intended to help TPWD protect this site in accordance with State of Texas Health and Safety Code requirements governing cemeteries, specifically Chapter 711. Archival and field work was accomplished in April and May, 2009 under Texas Antiquities Permit Number 5203, issued to Jon C. Lohse.

\section{Report Organization}

This report is organized into a total of five chapters and 3 appendices, including this introductory chapter. Chapter 1 includes the regulatory and site evaluation criteria for archaeological sites located within the park. Chapter 2 provides in detail an overview of the environmental setting and the cultural background of the study area. Chapter 3 describes the project's research goals and the field methods employed. Park area descriptions and the results from the shovel tests conducted in the 2009 survey are outlined in Chapter 4. Chapter 5 presents the recommendations and overall conclusions made from the investigations performed in 2009. 


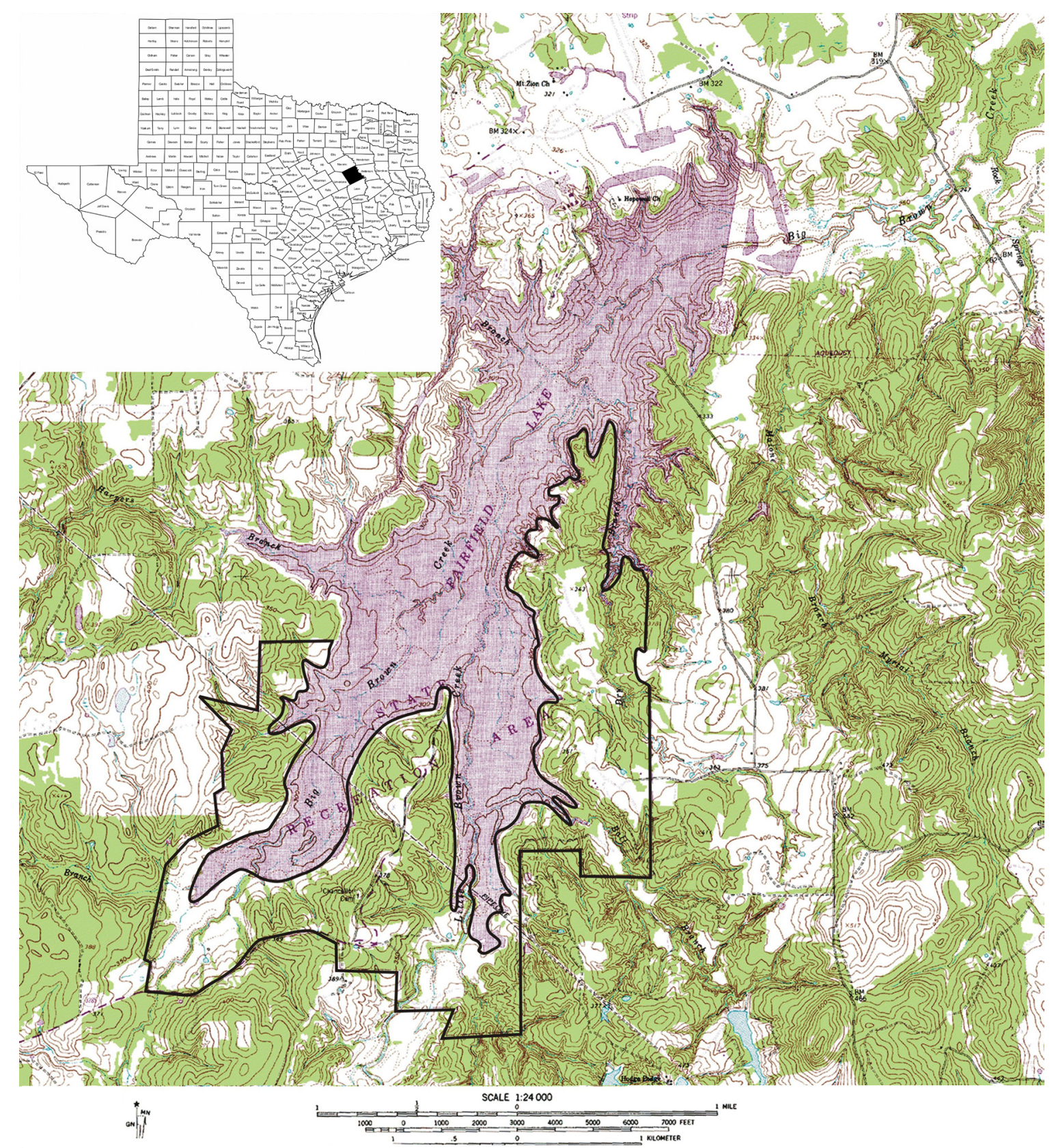

Figure 1-1. Location of Fairfield Lake State Park and survey area of the 1996 project plotted on the Young 7.5' United States Geologic Survey topographic sheet. Inset map shows location of Freestone County in Texas.

Appendix A presents the profiles of shovel tests excavated in response to isolated finds during the 2009 work; not all of the over 200 shovel tests excavated during this project are described in this fashion, only those conducted in response to observed cultural materials. Appendix B is a list of all recorded sites, their components, and assigned management priority levels. Information in Appendix B is derived from the conclusions presented in the previous survey (Yelacic et al. 2008), and is presented here for ease of reference. Appendix $\mathrm{C}$ is a United States Geological Survey (USGS) 7.5' Quadrangle map illustrating the locations of 
recorded sites, recently excavated shovel tests, and park features. This map, located at the back of this report, is only included in copies not intended for public distribution.

For this project, Dr. Jon Lohse served as Principal Investigator; he also participated in the fieldwork on a limited basis. CAS Staff Archaeologist Julian A. Sitters was Project Archaeologist and supervised the day-to-day field work. Sitters was assisted by Sarah Scogin, CAS Staff Archaeologist.

\section{Archaeological Site Evaluation Criteria}

Although there are no immediate plans to develop the archaeological sites identified within the park, guidelines set forth by state and federal agencies for State Archeological Landmark (SAL) and National Register of Historic Places (NRHP) eligibility were used as a rubric for determining site significance. Cultural resources located on land owned or controlled by the State of Texas or its political subdivisions are protected by the Texas Antiquities Code (Code) (Texas Natural Resources Code, Title 9, Chapter 191), which classifies all sites as State Archeological Landmarks (SALs). Should any historic or prehistoric sites located on land that is designated for impact during development be determined eligible for formal designation of landmark status under the Code, some measure of protection or mitigation of impact may be necessary. The formal designation of SALs and their administration is the responsibility of the Texas Historical Commission (THC).

The Code generally requires that a complete archaeological survey be undertaken in conjunction with projects which fall under its purview, particularly in previously unsurveyed areas and in regions where cultural resources are expected. Any resources determined to be significant must then be avoided, protected, or their destruction mitigated by approved data recovery programs. Certain State agencies, such as TPWD, are proactively compiling inventories of cultural resources on their properties and for which they are responsible in order to assist them with their management responsibilities under the Code.

Worthiness for designation as a SAL is defined in the Code:

Archeological sites may be considered significant and be recognized or designated as State Archeological Landmarks, provided that at least one of the following conditions is met (Rules and Practice, Chapter 41:10):

The archeological site is situated on land owned or controlled by the State of Texas or one of its political subdivisions; [and then]

(A) preservation of materials must be sufficient to allow application of standard archeological techniques to advantage; and/or

(B) the majority of artifacts are in place so that a significant portion of the site's original characteristics can be defined through investigation; and/or

(C) the site has the potential to contribute to cumulative cultural history by the addition of new information; and/or

(D) the site offers evidence of unique or rare attributes; and/or

(E) the site offers a unique or rare opportunity to test techniques, theory, or method of preservation, thereby contributing to scientific knowledge.

Archaeological sites identified as significant cultural resources may be protected by federal 
law, primarily by the National Historic Preservation Act (NHPA) of 1966, which is invoked when federal funds are utilized or when federal permitting is required for a proposed undertaking. The NHPA created NRHP, and states that the Advisory Council for Historic Preservation (ACHP) must be afforded the opportunity to comment when any cultural resources potentially eligible for inclusion in the NRHP are present in an area affected by federal agency actions, or by any actions funded or permitted by federal agencies. The federal regulatory process is described in detail in the ACHP regulation 36 CFR 800.

Protection of cultural resources under federal law is tied to eligibility for the NRHP, which depends on site significance as defined by National Park Service (NPS) rule 36 CFR Part 60. Four criteria are applied to archaeological sites in determining their significance. These address properties that are:

(a) associated with events that have made a significant contribution to the broad patterns of our history; or

(b) that are associated with the lives of persons significant in our past; or

(c) that embody the distinctive characteristics of a type, period, or method of construction, or that represent the work of a master, or that possess high artistic values, or that represent a significant and distinguishable entity whose components may lack individual distinction; or

(d) that have yielded, or may be likely to yield, information important in prehistory or history. 


\section{Chapter 2}

\section{Project Setting and Cultural Chronology}

by David M. Yelacic and Julian A. Sitters

\section{Project Area Setting}

Freestone County occupies 892 square miles in northeast Central Texas. The eastern border of the county is demarcated by the Trinity River, and the project area, Fairfield Lake State Park, is located at the confluence of Big Brown Creek and Little Brown Creek, secondary tributaries of the Trinity River.

\section{Post Oak Savannah}

As recently defined by the United States Environmental Protection Agency (USEPA), the United States Geographic Survey (USGS), and other federal and state agencies using a fourtiered hierarchical framework with climate, vegetation, physiography, and other biotic and abiotic phenomena taken into consideration, Fairfield Lake State Park lies within the Level III ecoregion East Central Texas Plains (Griffith et al. 2004) (Figure 2-1). As described by Fields (1995) and supported by Griffith et al. (2004), the East Central Texas Plains, also referred to as the Post Oak Savannah, separates the prairies to the south, north, and west from the Piney Woods to the east. Accordingly, this region is a transitional one consisting of irregular plains and containing stands of pine trees intermixed with hardwoods such as mesquite, oak, and hickory. However, much of the area now encompassed within the state park was once modified as pasture or farmland. According to park ranger Don Boyd, once the area was leased by TPWD much of the land returned to its natural setting with the help of annual burns and ecological restoration projects (personal communication 2009).

\section{Fairfield Lake}

In the late-1960s, Dallas Power and Light Company, Texas Electric Service Company, and Texas Power and Light Company acquired land at the confluence of Big Brown and Little Brown Creeks in order to construct the Big Brown Steam Electric Station (Jansinski 2002). Plans for construction included creating a 2,500-acre, 15 billion gallon lake, which would be used to cool the two generators. Before the Big Brown Steam Electric Station was erected in 1969, Big Brown Creek was dammed. Big Brown Creek, a secondary tributary of the Trinity River, flows from its headwaters northeast for approximately 20 miles to where it empties into the Tehuacana Creek, a primary tributary of the Trinity River.

\section{Sediments}

Soils in the project area have been mapped and described by Janak and Griffin (2002) (Figure 2-2). Units include Edge fine sandy loam, 5 to 12 percent slopes (EgE); Nahatche-Hatliff association, frequently flooded (NH); Rader fine sandy loam, 5 to 12 percent slopes (SaE); Silstid loamy fine sand, 1 to 5 percent slopes $(\mathrm{SsB})$; Silstid loamy fine sand, 5 to 8 percent slopes (SsD); and Tabor fine sandy loam, 1 to 3 percent slopes $(\mathrm{TaB})$. Depending on series, soils in the region can be classified as A-Bt-C (Ege/TaB), A$\mathrm{Cg}(\mathrm{NH})$, and $\mathrm{A}-\mathrm{E}-\mathrm{Bt}(\mathrm{SaE} / \mathrm{SsD})$. 


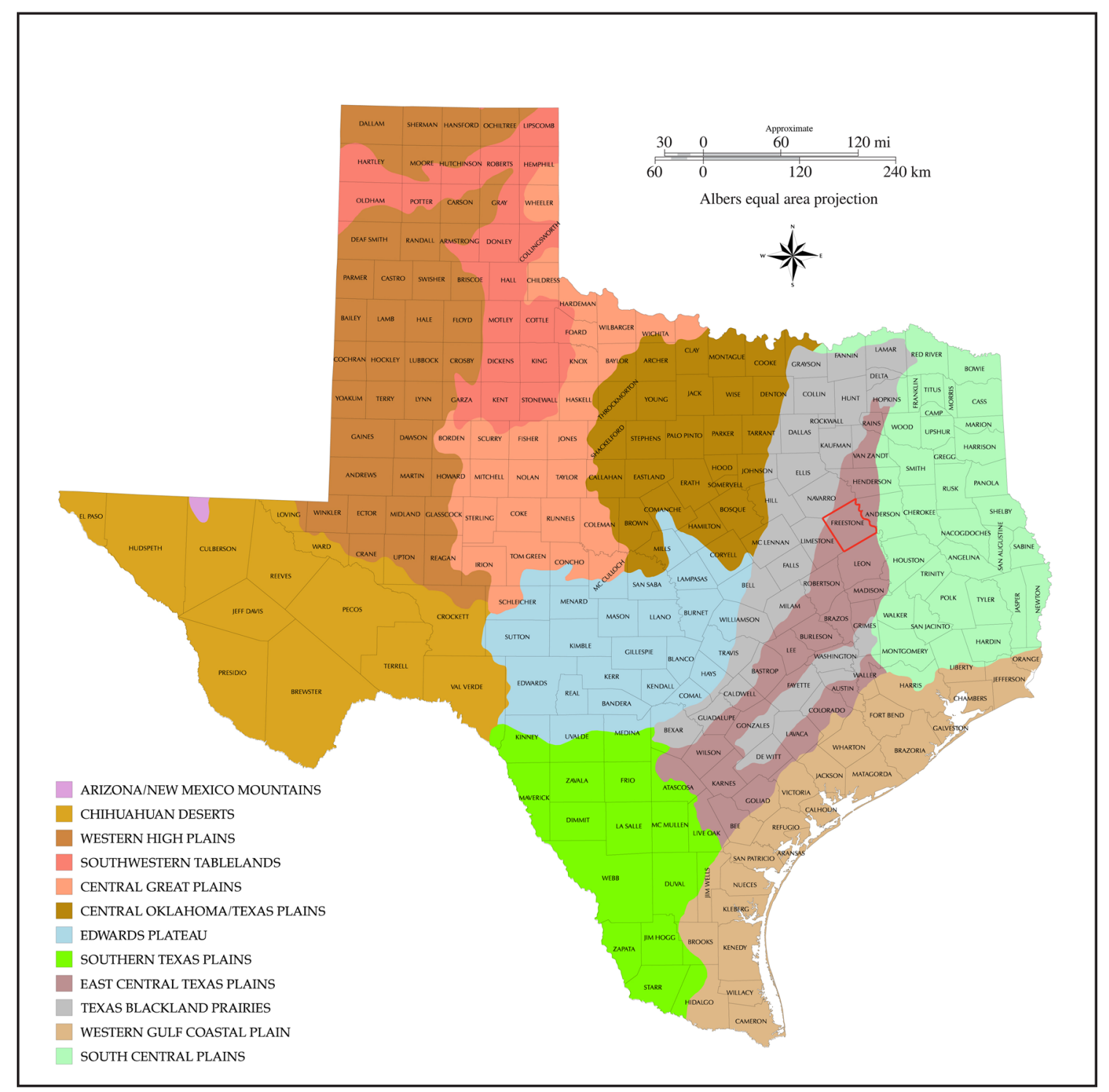

Figure 2-1. Level III Ecoregions map of Texas with Freestone County outlined in red.

Most of these soil associations are found on flat to nearly flat terrain. However, the high sand content leaves topsoil deposits vulnerable to runoff and erosion during even light-tomoderate rainfall events. Typical soil depths are often shallow, averaging from as little as $7.6 \mathrm{~cm}$ in depth $(\mathrm{SaE})$ to approximately $66 \mathrm{~cm}(\mathrm{SsD})$. Subsoils are very often high in clay content, which causes surface water to pool in spite of the permeability of the topsoils. These soils support a limited range of uses, the most notable of which are as pasture and agricultural lands. Salt domes in the southern part of Freestone County (Janak and Griffin 2002:116) are associated with some oil and natural gas production. Additionally, lignite coal deposits are present in the region and have been actively mined for the past several decades and up to the present. 


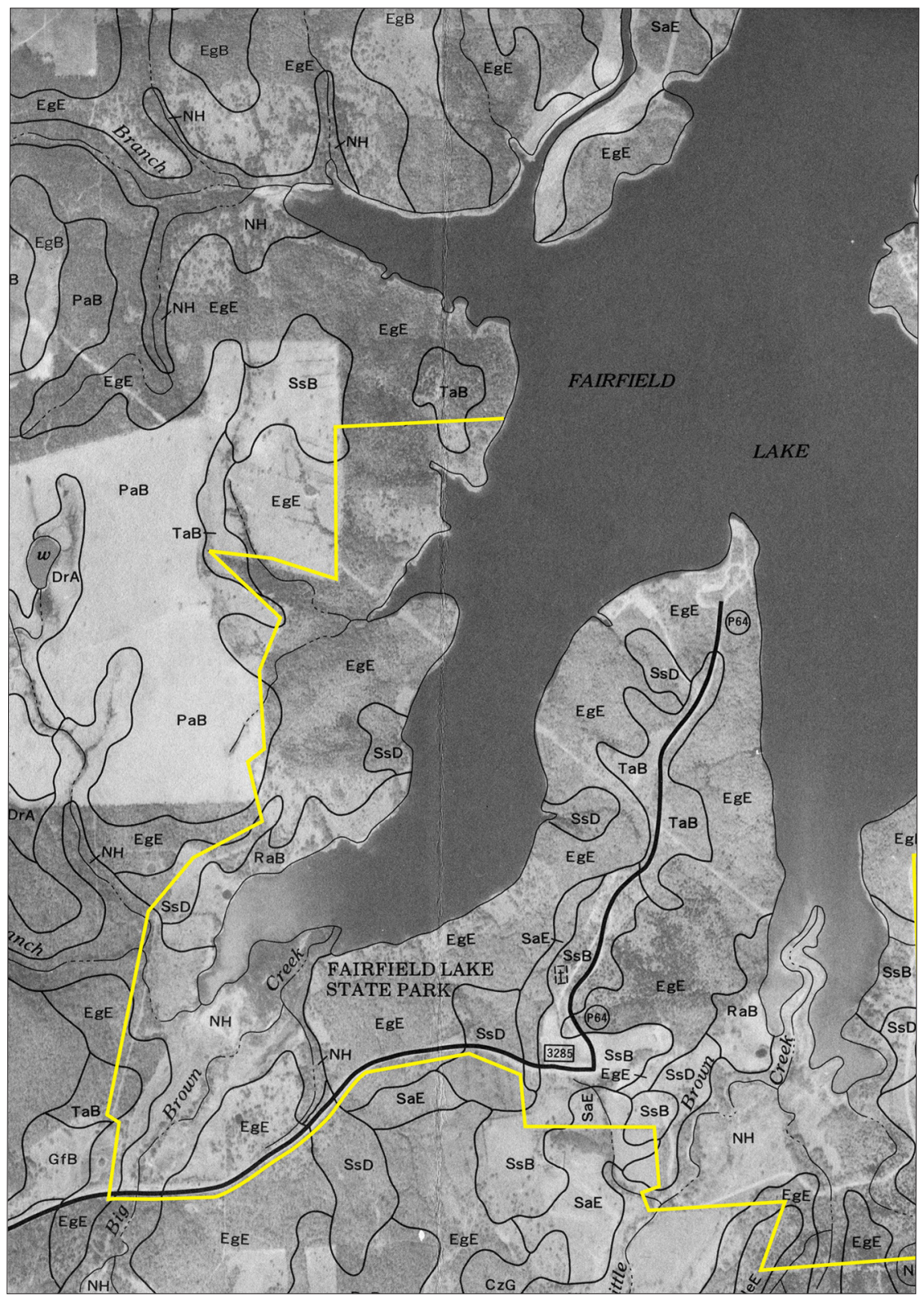

Figure 2-2. Soils found across Fairfield Lake State Park, bounded in yellow (after Janak and Griffin 2002:Plate 19).

\section{Cultural Disturbances}

Cultural materials within the confines of the park have been affected by multiple natural and artificial factors over the years that have seriously impacted the integrity of many of the sites that are present. The most common and ongoing cultural disturbance within the park is erosion. As a result of the sandy sediment composition within the park area, topsoils are continuously impacted by erosion and runoff. Park construction and maintenance also influences poor site preservation. Road, park building, campground, and pipeline construction has disturbed a substantial amount of area within the park. Finally, prior to the development of the park, the area was cleared of any standing 
structures or obstructions which were thought to potentially pose a hazard to the public. Historic structures, stock pens, and old fence lines, which stood prior to the opening of the park, were systematically dismantled (Jasinski 2002:77) and either removed from the park or relocated and buried. This information was confirmed by Park Ranger Don Boyd (personal communication, 2009). These factors have contributed to the poor archaeological site preservation within the park.

\section{Cultural Chronology for Northeast Central Texas}

Abundant waterways and fertile land have long lured human occupation to northeast Central Texas. The rich human occupation of the region, divided into prehistoric and historic components, is presented in the following paragraphs.

\section{Prehistoric}

Previous investigations have shown that the greater east Central Texas region shares cultural affinities with Central Texas, East Texas, and north Central Texas (Bruseth and Moir 1987); diagnostic artifact types from each of these three regions can be found here. In terms of prehistoric occupation, the Post Oak Savannah region is best known for its Late Archaic and post-archaic Woodland adaptations (Fields 1995). Although some findings dating to the Paleoindian and Early/Middle Archaic periods are present, these tend to be scarce. The following cultural chronology of the Prehistoric period is based on the research and interpretations of Dee Ann Story (1965) and Ross C. Fields (1995, 2004). A compilation of their data divides the region's prehistoric occupation into four periods whose titles reflect the overlapping of neighboring regions: Paeloindian, Archaic, Woodland, and Late Prehistoric. Supplementing the cultural chronology of northeast Central Texas with comparisons of adjacent cultures is necessary due to the mobile nature of early populations and the dispersive quality of culture. Division within the prehistoric occupation of the region is not meant to indicate discrete temporal units in the region's cultural chronology. Dates provided are approximated in radiocarbon years before present (B.P.).

\section{Paleoindian}

The Paleoindian period, as seen in divisions ofCentral Texas Cultural chronology as predating 8,800 years B.P., is hardly visible in northeast Central Texas' material record. It is represented by scattered, isolated finds of temporally diagnostic dart points including Clovis, Folsom, and Angostura (Meltzer and Bever 1995; Story 1965). Paleoindian discoveries in the region are typically surficial, but they do exist and have been found in subsurface contexts (Fields 1995, 2004; Richner and Bagot 1978). Unfortunately, the subsurface discoveries show evidence of disturbance representing either post-depositional erosional movement or later population's interest in archaeology. The lack of available evidence from the region results in reliance on general trends in Paleoindian populations provided by studies of the earliest occupants in Central and East Texas.

A large distribution of Clovis points across North and Central America suggests a wide dispersal of their makers (Wenke 1990:201). Meltzer and Bever (1995) documented the presence of 406 Clovis points at 128 of the 254 counties in Texas. These early populations in Texas were most-likely small groups of highly mobile, specialized hunter-gatherers. Herds of megafauna and the availability of edible flora are the assumed forces behind the migration of early populations toward the plains of northeast Texas (Perttula 1995, 2004). 


\section{Archaic}

Archaeologists' ability to clearly discern differences between traditional Archaic components (i.e. early, middle, and late subperiods) is often hindered by a number of factors. These include the sandy nature of regional sediments, which facilitates the translocation of artifacts beyond original component boundaries and therefore obscures otherwise stratified deposits; the deflated nature of many upland settings; and the generally poor temporal resolution of diagnostic artifact types (Fields 1995). In general, however, the long Archaic occupation (ca. 8,800 to 1,200 years B.P.) of the region is characterized by the gradual emergence of strongly localized cultural traditions; overall reduction in annual and seasonal mobility; an apparent diversification of subsistence resources in response to increasing fluctuations of climate, available moisture, and plant and animal communities; and a corresponding diversification of regional artifact styles and technologies that were designed to exploit this quickly changing environment.

Story (1965) describes Archaic sites as having a high percentage of expedient cutting/ scraping tools and rectangular/expanding stemmed, temporally diagnostic dart points. Burned rock features also appear in association with Archaic sites. Sites studied in northeast Central Texas show a concentration of lithic material around burned rock middens and/or hearths, but the environment does not support preservation of floral and faunal remains (Fields 1995, 2004). Evidence suggests that Archaic sites in the region, though slightly and understandably deflated, are in their original context. These sites indicate short-lived, isolated occupations and suggest that their inhabitants were still mobile hunters and gatherers.

\section{Woodland}

Woodland adaptations appear not only in the study area by approximately 1,800 years B.P., but also across the greater Trans-Mississippi south of the southeastern United States (Story 1965). This period is characterized by the introduction of ceramics (in some areas); partial reliance on cultigens, particularly as a complement to seasonally available foraged goods; more prolonged stays at certain locales; social and ritual elaboration; and, later on, the introduction of the bow and arrow. The adoption of ceramic technologies by approximately 1,700 years B.P. implies increasing emphasis on storage of certain foodstuffs. Early vessels are thick and have only simple surface treatments. Temper materials frequently utilized include sand or clay, bone, and grog. Gary points, with sharply triangular blades, contracting stems, and strong shoulders are perhaps the most common point type. Woodland adaptations are more clearly distinguished to the east of the study area, though many of the traits just described are found in Freestone County.

While postholes are evidence of increasing intensity and longevity of site use, postholes, or possible postholes, and intrusive pits associated with Woodland deposits occur in low numbers. The presence of cultivated botanical remains would suggest that the economy of this time period was transitional, however, the lack of prominence in the organic material record indicates that the populations did not significantly rely on horticulture (Fields 1995:307). The increase in domestic activities represented in the material record from Woodland cultural deposits are evidence of increasing population densities, decreasing mobility, and the multi-seasonal use of sites, which Fields (1995:307) describes as "residential bases" (Perttula 1990:276-277, cited in Fields 1995). 


\section{Late Prehistoric}

The Late Prehistoric period occupies the time from ca. 1200 years B.P. to ca. 500 years B.P. (Fields 1995, 2004; Story 1965). The introduction of the bow-and-arrow, the intensification of food production, and the elaboration of architectural forms and ceramic technologies define the Late Prehistoric period. It is notable that despite the prominence of arrow points, dart points continue to be recovered from this period's cultural deposits, suggesting that atlatl and bow-andarrow technologies overlap (Fields 1995:310). Structures of this time period are more common. Postholes indicate sub-rectangular to rectangular shaped structure, and at some sites, postholes overlap indicating multiple construction events (Fields 1995, 2004). Intrusive pits, hearths, trash middens, and burials associated with remnants of structures are evidence of increased domestic activity and the spatial distribution of intrasite activities (Fields 1995). Botanical remains from cultivated species, as well as foraged species, are present in association with Late Prehistoric cultural deposits and are evidence of an increased reliance on horticulture (Fields 1995, 2004). However, the botanical evidence still indicates that these populations relied mainly on wild plant food. Despite the more dominant structures, spatial patterning of activities, and evidence of increased horticulture practices, there is no evidence supporting year-round, sedentary occupations of this region's populations during the Late Prehistoric period (Fields 1995). Ceramic technology of this period continues to advance and plays a more prominent role in the culture. Although sherds recovered at many sites are too small to indicate any specific type of vessel, a low percentage does reveal some important stylistic innovations. Decoration including neckbanding, incision, engraving, punctation, and pinching show evidence of trade with and/or cultural influence from Caddo neighbors to the north and east (Fields 1995:315). Contemporary
Caddoan groups in the Piney Woods and Red River regions are considered to have more complex social systems than the populations in this region (Fields 1995; Perttula 1995).

\section{Historic: A Brief History of Freestone County}

The history of Freestone County, and, specifically, the land that now constitutes Fairfield Lake State Park, is provided by a report written by Laurie E. Jasinski (2002) on behalf of TPWD.

European exploration of the county began as early as 1542 . According to a 1939 study by the United States De Soto Commission, Luis de Moscoso Alvarado led an expedition that may have traversed the county. More definitively, the 1690 s was a decade in which trails including the Upper Presidio Road, which skirted the southern border of present day Freestone County, were improved upon and provided a route for Spanish explorers, militia, government officials, and clergy to travel between east and south Texas. In the eighteenth century, Spanish colonists and French explorers and entrepreneurs, who were navigating east Texas' plentiful waterways, took notice of Native American groups migrating into the region. Nomadic groups followed bison into the area while groups of semi-sedentary people found fertile land and abundant trade with other indigenous groups and Europeans.

During the transition from the eighteenth to the nineteenth century, American explorers from the colonies on the Atlantic coast began to venture into the region, much to the dismay of the Spaniards. One notable figure, Phillip Nolan, traveled through Louisiana and allegedly produced the first map of Texas; neither he or the map survived the final journey in 1801 as they were intercepted by Spanish soldiers. In 1821, Mexico, which then included the present state of 
Texas, gained independence from Spain. Unlike Spain's miserly views on settlement in the region, the newly formed Mexican government allowed individual states to regulate colonization on their own accord. The State Colonization Law of March 24, 1825 opened the door for the settlement of Texas. Subsequently, David G. Burnet of Ohio secured a contract with the Mexican government in 1826 to bring 300 families of settlers into Texas. However, financial misfortunes kept Burnet from executing his plan, and the rights to the land were sold to the Galveston Bay and Texas Land Company in 1830. Also in 1830, a suspicious Mexican government passed the Law of April 6th to put an end to the American colonization and influence of the region. Not long after American settlement in Texas was stemmed, the Mexican awarded two statesmen with significant land grants. Juan Nepomuceno Acosta, priest and one-time President of the Senate of the National Congress, and Mariano Rivas Palacios, who would later become the governor of the State of Mexico, received adjacent land grants of 48,712.4 acres each. In 1832, before the land was officially surveyed and awarded, Mariano Rivas Palacios turned over his land grant rights to his grandson, Enrique Antonio Mexia. The Mexia family, at an unknown date, either claimed or purchased the Acosta grant and consequently controlled a sizeable tract of land. All the while, these bureaucratic exchanges of land rights did not affect the occupying groups of Native Americans.

Independence from Mexico gained by the Republic of Texas in 1836 added more to the confusion over land ownership. In the middle of the nineteenth century, the area that would later become Freestone County was largely unsettled. Surveyors plotted new tracts with no regard to the previous titles, such as the Mexia family's and the Republic of Texas issued headrights to citizens and immigrants. Benjamin Edwards of
North Carolina was an early settler of Freestone County, and in 1847, he received a headright that included land adjacent to Big Brown Creek. It is possible that his property extended to the present Post Oak Campsites in the northeast corner of Fairfield Lake State Park. Headright parcels adjacent to Edward's were surveyed and awarded throughout the 1840s and 1850s, but rights to the grants were exchanged several times. In some cases, headrights were forfeited and the title defaulted to the Mexia family. Shortly after the annexation of Texas into the United States in 1845 , migration to the region increased with a majority of the population coming from southern states. Many families who settled the area near Big Brown Creek came from Wilcox County, Alabama. In the early days of Fairfield, which was officially established in 1851 as the county seat of Freestone, farms fueled the economy and the Trinity River provided transportation to market places. Many of the pioneer families brought their slaves and established farms or plantations to grow cotton, corn, and tobacco.

In 1851, Benjamin Edwards sold his headright to Dr. William D. Strain. The Edwards family moved to what is presently the southwestern portion of the park, and the Strain family set up a cotton plantation. Also settled in the southern end of the present park was the Chancellor family. In the 1850s, the Chancellors and their slaves moved to Freestone County from Wilcox County, Alabama. On the Chancellor's parcel, a one-room church and school was built. An adjacent cemetery, the Chancellor Union Cemetery, served as the final resting place for members of the Chancellor family, other related families, and their slaves. Another prominent family along Big Brown Creek was the Oliver Family. William W. Oliver, a wealthy merchant and landowner in Limestone County, purchased land from the Mexia family, a 1,100-acre tract that the Olivers had occupied for half of the previous 
decade. One of W. W. Oliver's daughters married into the Stroud family, one of the largest slave holding families in Freestone County. Slaves were figuratively invaluable to the farming community of Freestone County. In the years before the Civil War, Freestone County was one of the leading slave and cotton counties in the state of Texas, and its economy and population prospered as a result.

In late 1860, on the verge of the Civil War, Freestone County voted 585-to-3 in favor of seceding from the Union. Many prominent members of the community served in the war, but of the 1,000 men that left, only 300 survived. During the war, plantations continued to thrive, and Freestone County's prosperity, owed in large part to free labor, went uninterrupted. The end of the Civil War and consequent Emancipation Proclamation marked the beginning of difficult times for the economy of the county. White and black families alike struggled with the economic and social changes. During Reconstruction, many freed slaves continued to work land belonging to their former masters as sharecroppers. Impoverished white families also found work as sharecroppers and tenant farmers, and this agricultural practice continued into the 1960s in Freestone County. In the 1870s and 1880 s, although railroad lines just grazed the county's borders to the north and south, the proximity of the railways to Fairfield allowed the population and the number of farms to increase significantly.

Land adjacent to Big Brown Creek, which would later become Fairfield Lake State Park, was maintained by many of the families that had acquired or purchased the land prior to the Civil War, but a few tracts were often exchanged between residents of the county. The east side of the present park was consistently owned by the Oliver and Stroud families to the turn of the twentieth century, and the Chancellor family maintained the southern portion of the present park into the 1900s. The Hill family purchased the Oliver/Stroud tract in the early 1890s, and soon became a prominent family in Fairfield. The Huckaby, McDonald, and Miller families were also notable newcomers to the land adjacent to Big Brown Creek. On the Chancellor tract, the one-room building that was both a church and a school continued to serve the growing farming community. Cook's Ferry Road and a number of back roads connected the Big Brown Creek area farming families with each other, Fairfield, and the Trinity Rivers. Natural gas and oil discoveries in the region during the early twentieth century introduced new prosperity to the economy. While land leasing and prospecting grew rapidly, farming continued to lead the area's economy. However, in the 1920s, farming in Freestone County went into decline in response to the Great Depression and the boll weevil infestation. Small farmers and tenants also felt the strain of an ever-worsening situation as population size increased, decreasing the mean farm size, and soil depletion and erosion affected the quantity and quality of their cash crops (Bruseth and Moir 1987:22). In order to compensate for the failing agricultural market, some rural residents turned to bootlegging liquor in the 1920s. Through the Prohibition era, Freestone County became nationally recognized for its quality and quantity of whiskey, known as Freestone County Bourbon Deluxe (Leffler 1978). Despite attempts by local authorities, this illegal industry persisted for several decades, and constituted a significant if illicit economic adaptation that allowed many individuals and families to subsist through an otherwise dismal period. Since the beginning of the twentieth century oil discoveries in the area prompted periods of growth and success for some landowners (Bruseth and Moir 1987:22). The oil industries presence can still be felt today throughout Freestone and surrounding counties 
with 44, 889, 337 barrels of oil produced since production began in 1916 to 2004 (Leffler 1978).

While the Depression forced some of the Big Brown Creek area families to part with their land and move on, it provided the opportunity for other families, the Hill family specifically, to increase their holdings. In the 1930s and 1940s, the Hills bought large tracts from the Huckaby and McDonald families. When land surrounding Big Brown Creek was bought out by the energy companies in the 1960s, the Hills owned a majority of the property that would become the park. In the 1930s, the one-room church and school on the Chancellor tract was struck by lightning and burned down. It was never rebuilt, and the Chancellors sold their property to the Bonner family in 1947. The Bonners were an old and prominent family in the county, at one time operating one of the largest plantations in the county and contributing significantly to the development of the Masonic Lodge and Fairfield Female College. With the beginning of World War II and into the 1950's rural populations began to decline in a response to the opportunities offered within large urban centers (Bruseth and Moir 1987:22).

In the 1950s, what was left of tenant farms faded into pasture and range for cattle ranching. Agribusinesses began to move into the surrounding region and acquire land holdings. What was once family run plantations soon became part of an ever-growing business within the area. The overgrown fields and old roads also provided recreational areas for descendants of the families who had settled the region.

\section{Previous Archaeological Investigations}

Freestone County's proximity to the Trinity River provides living conditions that humans have found suitable since the early Holocene. The county has rich subsurface mineral resources and an abundance of waterways, and these natural resources have long been exploited. In recent history, developmental protocols requiring cultural resource investigations prior to construction have added significantly to the archaeological record of the area. Three regionally relevant, large scale investigations, including the Jewett Mine Project, Tennessee Colony III project, and Richland/Chambers project, will be discussed briefly. The current project area, entirely within Fairfield Lake State Park boundaries, encompasses approximately 35 prehistoric and historic sites. Four of these, 41FT279, 41FT280, 41FT408, and 41FT409, all historic sites, were discovered during investigations prior to SFA's 1996 project. One site, 41FT630, was recorded by CAS during the 2008 project.

\section{Jewett Mine Project}

Jewett Mine is a 35,000-acre mining complex which supplies two Limestone Electric Generating Stations in northeast Central Texas with approximately 7.5 million tons of lignite per year (Westmoreland Coal Company 2008). This large operation required that a number of surveys, testing projects, and mitigations be performed by several private firms beginning in 1979. Investigations resulted in the discovery of 418 total sites (Fields et al. 1995). Of these 418 sites, 239 contained prehistoric components and 179 contained historic components. A total of 79 sites were tested and 17 sites were mitigated (Fields et al. 1995).

This extensive archaeological investigation reported by Fields et al. (1995) of Prewitt and Associates Inc., supplied basic knowledge about the prehistory of the region, which was previously not well understood. However, gaps in the project area's cultural chronology do exist. 
Occupation predating the Late Archaic period is not well represented as occupations associated with the Late Archaic, Woodland, and Late Prehistoric periods; therefore, little is known about the Paleoindian and Early to Middle Archaic inhabitants of the region. Evidence of the region's inhabitants during the early Historic period is not present in the material assemblage either. Another aspect of the region's prehistoric culture that is missing from the material record is evidence of subsistence practices before the Late Prehistoric. Unfortunately, the environment does not support the preservation of organic material.

\section{Tennessee Colony III and Richland/ Chambers Projects}

In the mid- to late-1970s, archaeological investigations were conducted prior to the construction of a dam that would create a large reservoir in the northern portion of Freestone County. Initially, the reservoir was going to be called Tennessee Colony Lake. Southern Methodist University's (SMU) Archaeology Research Program, on behalf of the Army Corps of Engineers, performed three surveys in the area that would potentially be affected by Tennessee Colony Lake; 311 prehistoric and historic sites were discovered (Richner 1982). Many of these sites, at the time, contained cultural material worth mitigating. Partly as a result of these finds, plans for Tennessee Colony Lake were abandoned for the Richland/Chambers reservoir. The Richland/ Chambers Reservoir was a fraction of Tennessee Colony Lake's size. The project area was also investigated by SMU's Archaeology Research Program. During investigations, a total of 53 prehistoric and historic sites were mitigated. Results of mitigations from prehistoric sites revealed trends similar to those of the Jewett Mine project; evidence of Paleoindian and Early to Middle Archaic occupations was minimal and evidence of conomic/subsistencepracticesbefore the Late Prehistoric period was not preserved
(Bruseth and Moir 1987). Extensive research of historic records and historic site mitigations was also performed during investigations for the Richland/Chambers Reservoir.

\section{Additional Investigations}

In addition to projects described above, which contributed tremendously to the understanding of the region's cultural chronology, archaeological investigations have been conducted within the boundaries of the Park prior to the current project. A review of files from the Texas Historical Commission's Texas Archaeological Site Atlas Database (Database) indicates that shortly after acquiring Park land by lease in 1971, TPWD conducted an internal Park Management Inventory of cultural resources. In 1972 George Kegley discovered sites 41FT279 and 41FT280, which were revisited by Ron Ralph in 1983; however, it appears that the only records of these sites appear on the Database in 1992, courtesy of Dan Crouch. Sites 41FT408 and 41FT409 were also discovered as a part of an internal management inventory, and although their dates of discovery are unclear, these sites were recorded on the Database in 1997 by Ron Ralph. Following initial Park Management Inventories, several small-scale investigations took place in order to secure project area clearances (d'Aigle 2006; Price 1983; Skinner 1983; Tiemann 2003, 2004). These small scale investigations were commonly performed prior to well or pipeline construction and not one of them identified cultural deposits within their respective project areas. In 1996, Stephen F. Austin State University (SFA) conducted a field school survey of the Park under the direction of Dr. James E. Corbin under contract with TPWD. This survey recorded and documented 30 new sites in addition to the four previously recorded sites, but due to unforeseen circumstances, the results of the survey and curation of the recovered artifacts were not completed. In 2008, CAS was contracted by 
TPWD to re-evaluate the recorded sites at the park based on their perceived NRHP potential and degree to which they were intact, and also to complete the documentation and curation that SFA had begun (Yelacic et al. 2008). The product of CAS's work in 2008 was intended to provide TPWD with a priority schema for managing sites in cases where impacts are foreseen from Park development and construction. A final site, 41FT630, was also recorded at this time. 


\section{Chapter 3}

\section{Project Goals and Methodology}

by Julian A. Sitters

\section{Project Goals}

The initial objectives of this project were to conduct an intensive archaeological survey for the park to ensure that all areas have been inspected for archaeological deposits, and also to conduct archival research sufficient for determining what can be known about the abandoned historic cemetery, 41FT630. CAS's efforts focused primarily on five distinct activities: (1) a review of existing county records that document the location(s) and name(s) of plotted cemeteries in Freestone County, as well as Freestone County marriage records in order to begin developing information about the identity of the woman, Ester Miles, whose headstone marks the cemetery location; (2) a review of historical maps and documents that might show the location(s) of historic buildings, homes, roads, and property lines, as these represent possible site locations; (3) pedestrian survey of the park boundaries excluding previously-recorded sites, waterways, and steeply sloping terrain; (4) shovel testing of probable areas for the presence of buried archaeological deposits; and (5) documenting contemporary features such as roads, pipelines, park dumpsites, and so forth that are present across the site and that obscure or obliterate any potential archaeological deposits that may have been in those areas.

\section{Archival Methods}

Archival records, including historic maps and marriage records, were reviewed prior to the pedestrian survey. Historic maps were evaluated in an effort to identify potential sites based on illustrated historic property lines, structures, and roads. Historic maps of Freestone County were accessed at the Dolph Briscoe Center for American History at The University of Texas at Austin and at the Freestone County Museum. Four maps, a Freestone County Starr Plat Map dating to the early half of the twentieth century, a 1922 United States Army Corps of Engineer Historic Topographic Map, a 1905 working sketch of Freestone County, and a 1948 General Highway Map of Freestone County, were reviewed. None of these maps depicted any standing structures in the project area, or provided any information regarding potential sites within the project area.

Other historic records that were consulted included the Freestone County marriage records for 1860s (1853-1883 Colored Marriage Records, Vol. 1-2:101). The lone grave marker present at the abandoned cemetery site 41FT630 names a woman named Easter Miles. Information pertaining to Easter Miles was assessed in order to identify the woman and to identify, if possible, the name of the cemetery where she had been interred. The only available information for Easter Miles came from the African American marriage records at the Freestone County Clerk's Office, located in the town of Fairfield. Easter Miles's marriage records showed her maiden name to be Strain 
and that she had married Robert Miles on the 22nd of February, 1868. Other than the marriage record no other information was found pertaining to her, and no named cemetery was identified where she was buried. Next, the Freestone County Clerk's Office was contacted and asked about platted cemeteries that were located in the park boundaries. The Office was unaware of any unmarked cemetery located within the Park, and knew only of the Chancellors Union Cemetery. CAS researchers also checked available maps showing platted cemeteries, and likewise could find no indication that 41FT630 has ever been platted. No other information pertaining to the unmarked cemetery was located.

Considering the date for Easter's marriage to Robert Miles, and that her maiden name was Strain, CAS suggests there a strong likelihood that Easter was one of the slaves owned by Dr. William Strain, who acquired property from Benjamin Edwards and operated a cotton plantation, as described in Chapter 2. This site is located in the same part of the park where Dr. Strain's property is believed to have been located, and it was a common practice for slaves to take their owner's last name.

\section{Field Methods}

After reviewing historical maps and documents, CAS archaeologists arrived at Fairfield Lake State Park in April of 2009 and began to familiarize themselves with the park. Using landscape features such as roads and creek beds, the region was broken into different sections for survey. Using smaller sections of acreage, the CAS crew was able to maintain greater accuracy in plotting locations of shovel tests and any items that were encountered or documented. Flagging tape was used to mark areas that contained isolated occurrences, such as glass bottles, cans, buckets, and so on, as well as areas deemed potentially suitable for structures and human occupation. Once each smaller section of the park had been covered in this fashion, CAS archaeologists returned to the areas marked with flagging tape to shovel test and inspect these areas more closely. Multiple shovel tests were excavated in these places to ensure that no additional remains were present at or just below the surface. Elsewhere, at least one shovel test was excavated for every 3 acres in accordance with minimal survey standards for project areas of this size that have been proposed by the Council of Texas Archeologists and adopted by the Texas Historical Commission. CAS archaeologists did not shovel test park areas that are consistently inundated, rest on a steep incline, or have been heavily impacted by park construction such as campsites or roads. Shovel tests measured $30 \mathrm{~cm}$ in diameter, and were excavated in $20-\mathrm{cm}$ levels to sterile subsoil or a depth of approximately $100 \mathrm{~cm}$ below surface (cmbs). All sediments were screened through 1/4-inch wire mesh, and all shovel test pits were backfilled after completion. A total of 215 shovel tests were excavated over the course of the field work.

\section{Field Documentation and Artifact Collection}

Shovel test forms were filled out for every excavated shovel test. Recorded information included the location of the shovel test based on proximity to park roads, the lake line, park buildings, and/or park trails. Vegetation in the vicinity of the shovel test was recorded, including the presence of trees, grasses, shrubs, and vines. Surface features were also recorded including geomorphological deposits such as surface gravel or exposed clay, the relative surface incline, as well as ground visibility. Other surface features include possible historic roads, agricultural fields, and wells. Using a 
Munsell chart, sediments were described based on their color and composition. The presence of gravel, water, roots, animal burrows, and compactness were described. Lastly, cultural debris and possible artifacts encountered during the excavation of a shovel test were noted. In the case of a possible site, maps were drawn and site boundaries were defined by excavating multiple shovel tests around the area of interest.

Digital photography was used to document the excavated shovel tests. A minimum of one general overview shot of each shovel test was taken to illustrate the natural environment, as well as one shot depicting the shovel test itself. When appropriate, additional photographs were taken of surface features, such as possible agricultural fields and historic roads.

Collected artifacts include complete bottles that display a maker's mark. Other artifacts, such as metal fragments, barbed wire fences, and bricks were photographed, described, and their location plotted. A final aspect of field documentation involved photographing items that had been confiscated by park personnel from park-goers trying to leave the premises with these items. Many such objects represent historic-period occupation in the park.

\section{Laboratory Methods and Curation}

Cultural materials collected from the Park were transported to CAS in San Marcos, Texas for processing and inventory in accordance with the TPWD Archeology Lab Manual. These materials consisted of a variety of bottles collected from the park. Once at the lab, they were washed, photographed, identified/dated, and added to the photographic record.

Photographs were compiled and organized in the lab. Each photo was given a identifying number in a sequence of all photos taken during this project, individually labeled and printed on acid free paper. A photo log was created that includes information on photo description, direction, location, date, and photographer. The photos and photo log were then enclosed in plastic protector sheets and compiled into two binders.

All field records, artifacts, maps, photographs (digital and hardcopy), and photographic logs were submitted to TPWD along with copies of this final report on acid-free paper. 


\section{Chapter 4}

\section{Park Area Descriptions and Results}

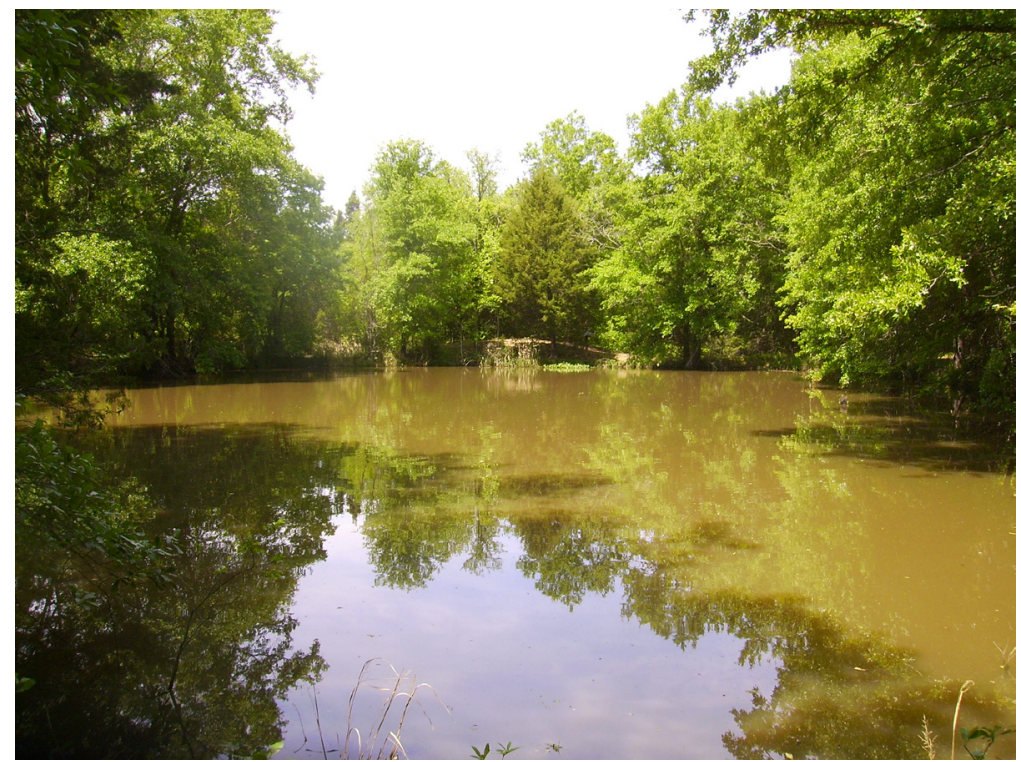

Figure 4-1. Pond located in the southwestern portion of the park, northeast of ST 95.

\section{Park Area Descriptions}

north of the pipeline (Figure 4-2). Trash associated with park visitors such as motor boat oil containers, shoes, beer cans, and coolers are present in this area. Vegetation consists mainly of tall grasses with some young trees present. Ground visibility is poor due to the presence of tall grasses and tree litter in the form of branches and leaves.

The occurrence of hog wallowing is very high in this area, resulting in severe disturbance at and just below the modern ground surface. Due to the repeated inundation from the impoundment of the lake and mixing of modern day

The park is composed of multiple geological and ecological settings. The following sections include brief descriptions of various areas within the park.

The southwestern portion of the park near the confluence of the Big Brown Creek and the lake shows signs of intense and repeated inundation. Many small drainage systems exist, as well as many stagnant pools of water and ponds (Fig. 4-1). Multiple small possible agricultural fields exist near the southern most portion of the park,

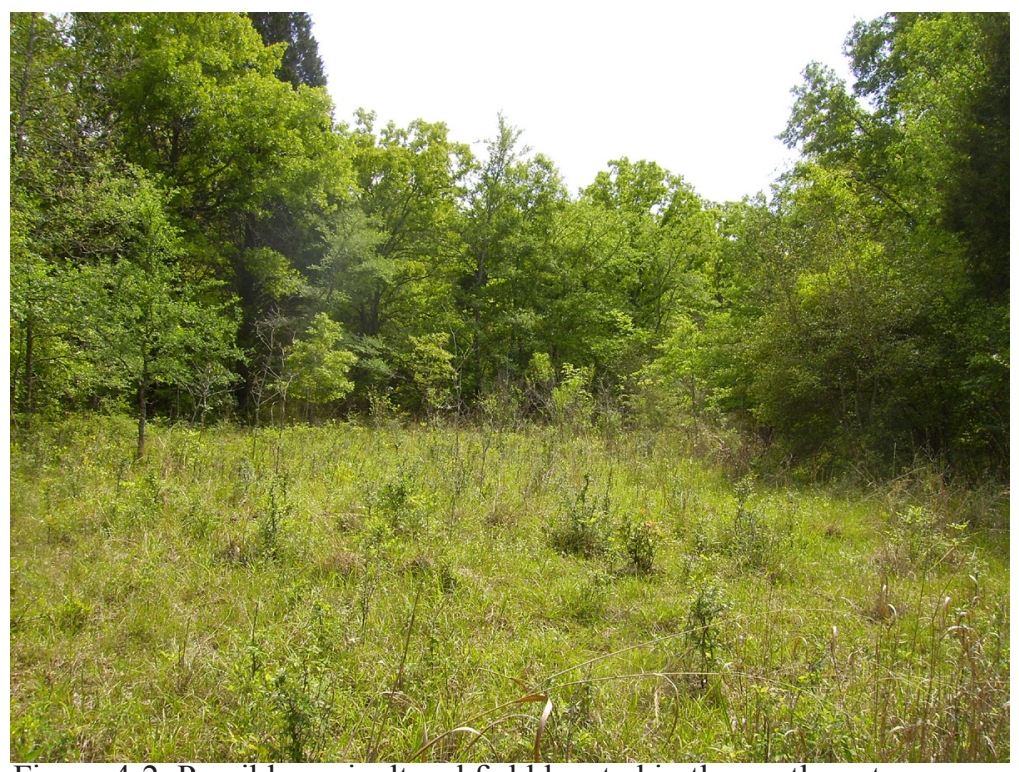

Figure 4-2. Possible agricultural field located in the southwestern portion of the park. 
trash, this area is considered to have poor potential for archaeological preservation.

The southern and southeastern portion of the park, near the intersection of the Little Brown Creek and Park Road has a dense understory. The low lying area in the southern portion of the park appears to be flooded frequently by the Little Brown Creek. Other portions of the low lying area collect water after moderate rainfall, due to poor drainage (Figure 4-3). This may have been an ideal area for agricultural fields, but appears to

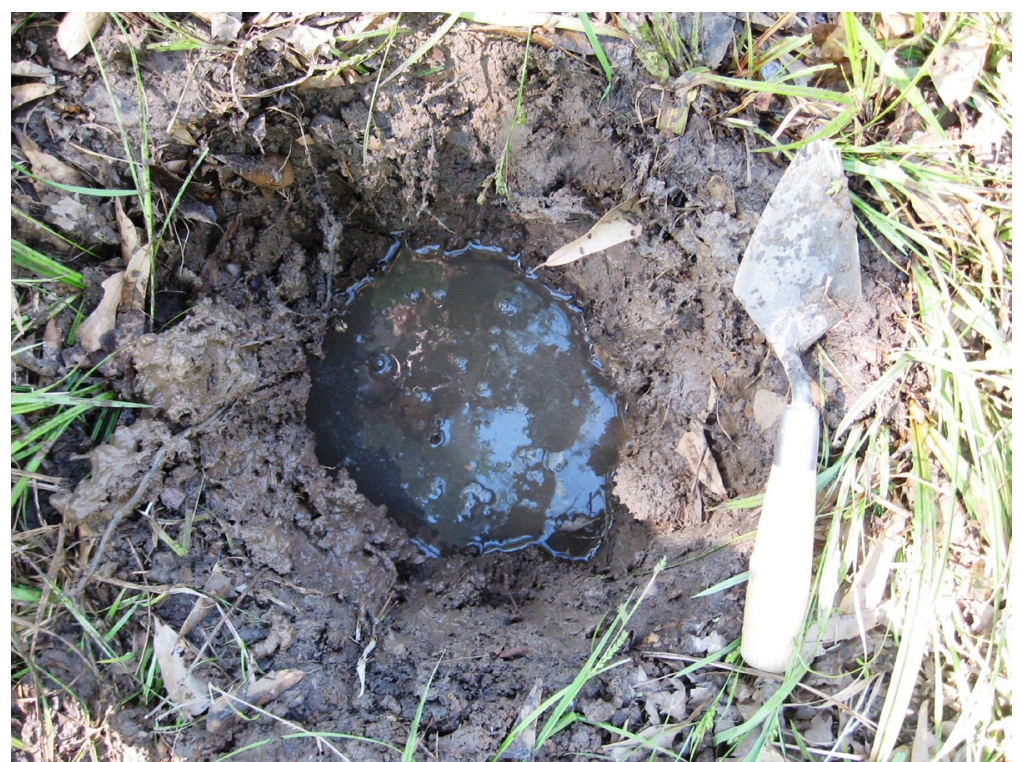
Figure 4-3. ST 100. Note the pooling of water at the bottom of the excavated shovel test. be less suitable for human occupation. Multiple agricultural fields were identified in these low lying areas (Figure 4-4). Similar to the southwestern portion of the park, the southern and southeastern areas have poor archaeological preservation due to the moderate flooding and pooling of water that occurs within this area.

The northeastern area of the park has very irregular terrain. The terrain ranges

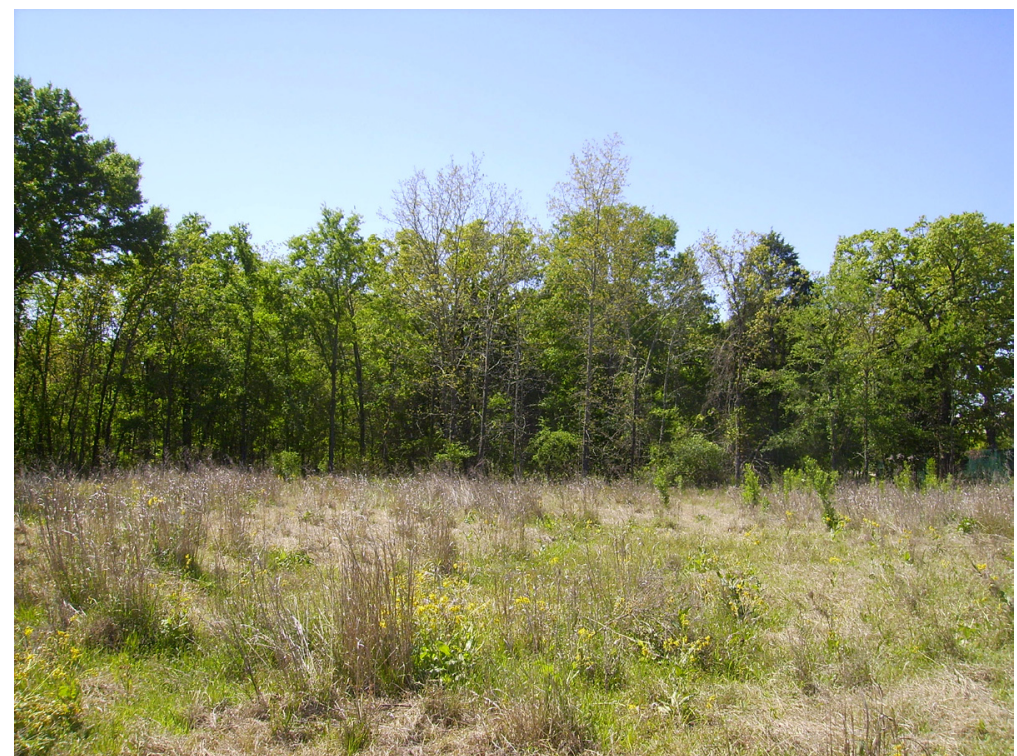

Figure 4-4. Possible agricultural field located in the southern portion of the park, southwest of the park headquarters. from relatively flat to steeply sloping. Multiple drainage systems dissect the area encouraging erosion and flooding. In most areas clay is present at the surface (Figure 4-5). The area consists of mixed hardwoods, mainly cedar, shrubs, and short grasses. Portions of this area have been periodically burned in an attempt to restore the park back to its natural environment. This results in multiple fields, consisting of tall grasses alongside the park road. Multiple camp grounds are present in this area near the lake line, as well as multiple primitive hiking trails, which are frequently maintained by park staff. Portions of this area are suitable for prehistoric occupation, specifically the area east of the Post Oak camp grounds.

The northwestern portion of the park, also known as the primitive camping area is bisected by multiple pipelines and drainage systems. The flora is composed of a thick understory consisting mainly of mixed hardwoods and shrubs (Figure 4-6). 


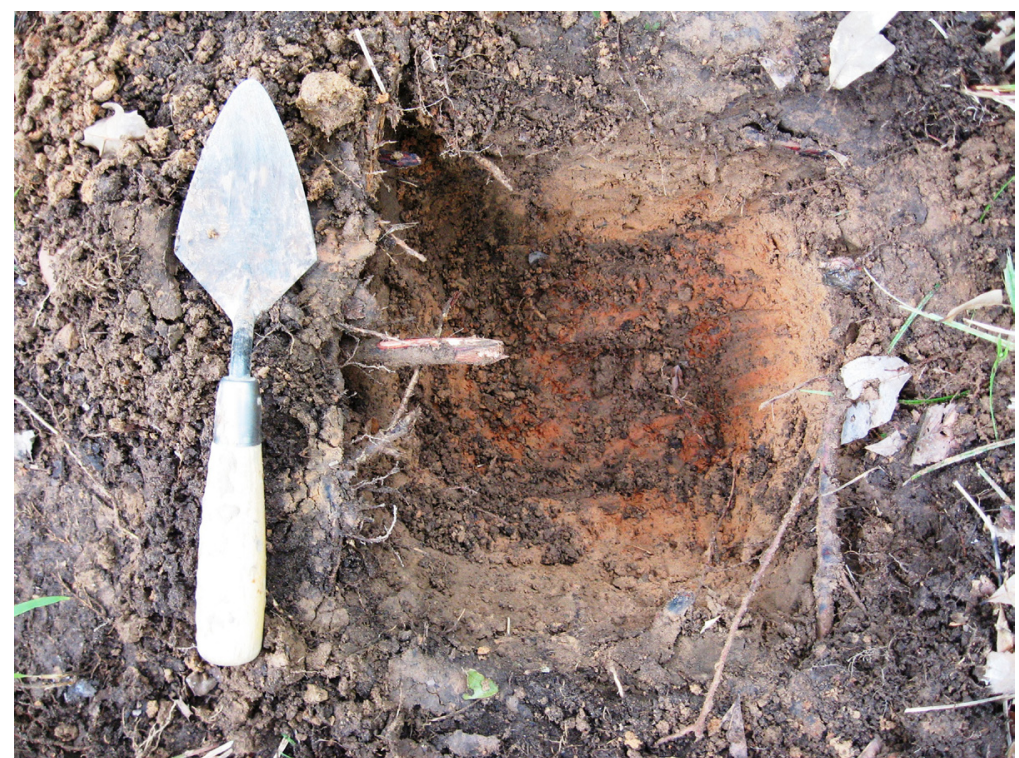

Figure 4-5. ST 210 located in the eastern portion of the park. Note the clay present just below the surface.

The terrain is irregular, sloping to the east towards the lake, leaving most of it unsuitable for structures. In the northwestern most portion of the park small possible agricultural fields exist near the lake line (Figure 4-7). Clay can be seen at the surface in most areas, having been exposed through erosion and revealing the diminished potential for intact buried cultural deposits.

\section{Survey}

The survey of the park produced multiple accounts of isolated finds. Artifacts typically consisted of barbed wire, glass bottles, metal fragments, ceramic sherds, and bricks. Despite the abundance of isolated items and remains within the park, all artifacts that were encountered and documented appear to lack any certain or meaningful context or association. None were associated with other materials, and none were part of an archaeological site. Rather, all such remains are interpreted as reflecting modern-era use and visitation of the park, dating approximately to the period when the park was first established until recently.

The most common and abundant artifact identified within the park boundary is barbed wire. When barbed wire was located it was plotted on a map and documented. All of the barbed wire located within the park was identified as $121 / 2$ gauge strands with flat, two point tapered

The Central and Northern portions of the park seem most suitable for human occupation. The ideal areas have been disturbed by pipelines, roads, public use areas, and park-staff housing. The remaining portions are bisected by drainage systems and are sloping towards the lake. The flora consists mainly of short grasses and mixed hardwoods (Figure 4-8). The depth of clay varies from $100 \mathrm{cmbs}$ to right at the surface (Figure 4-9). A number of previously recorded sites are found in this area.

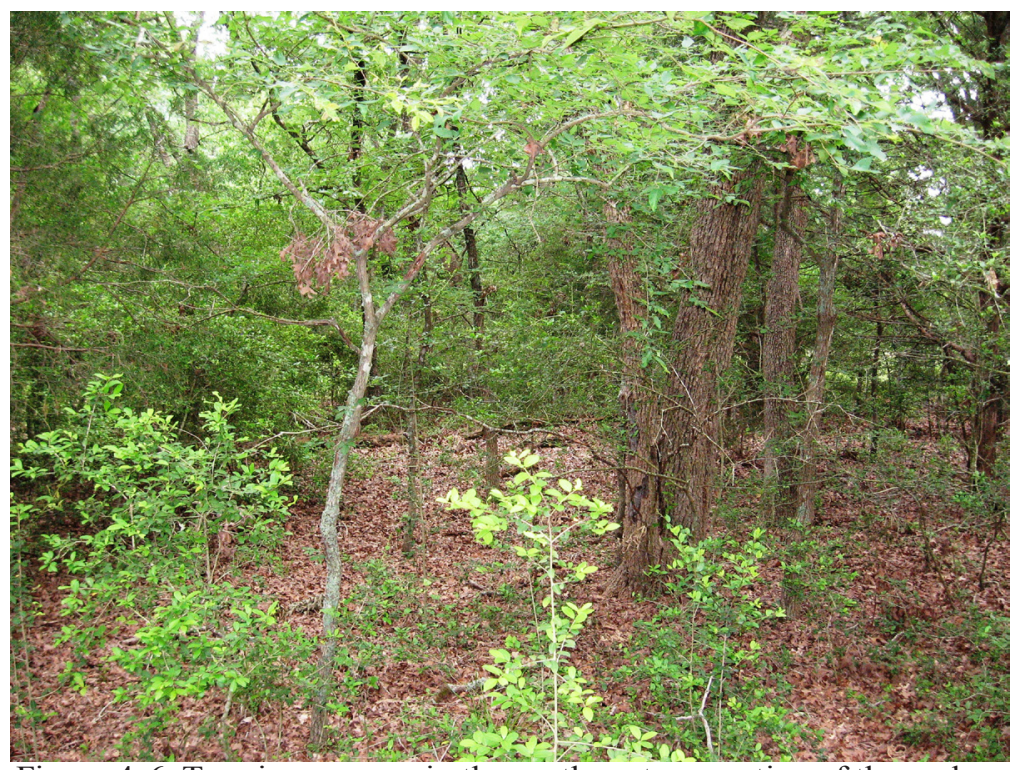

Figure 4-6. Terrain common in the northwestern portion of the park. 


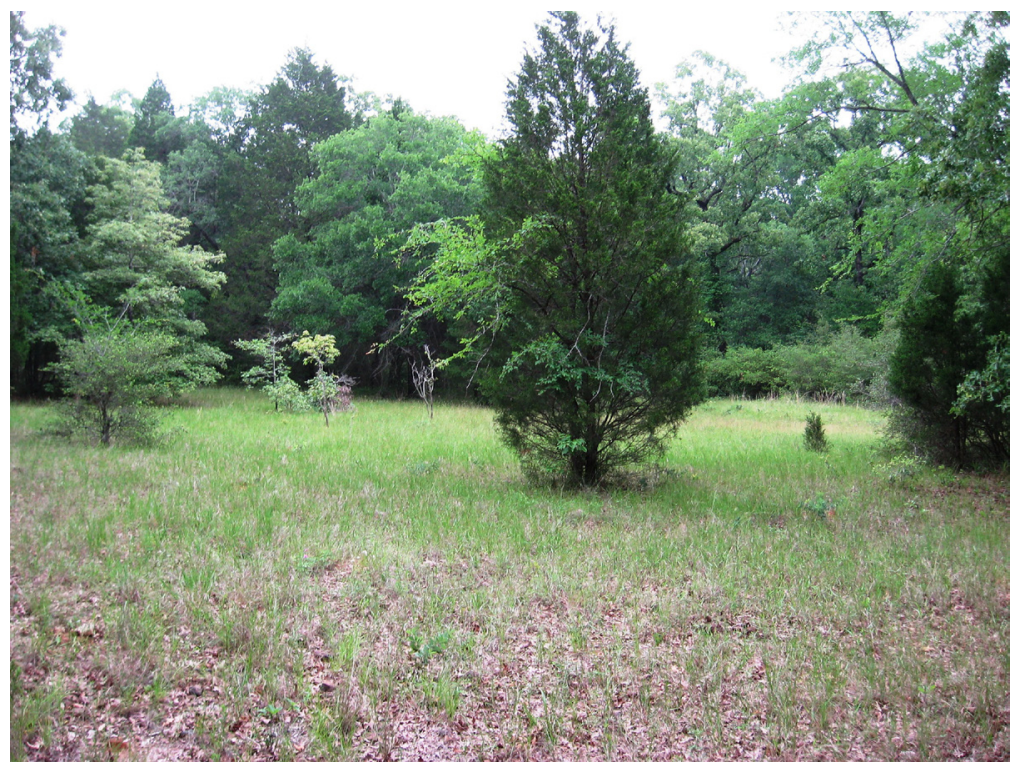

Figure 4-7. Possible agricultural field located in the northwestern portion of the park.

barbs. This style of barbed wire was patented in 1883 by George C Baker (Hagemejer 2001). This barbed wire form remained constant from 1883 to the present. It is still in production today making it difficult to date the barbed wire found within the park boundaries. The only distinction that can be made between the isolated barbed wire fragments is the method by which it was fastened to vertical posts. In some instances, the barbed wire was attached to a tree, and over time trees have grown over the barbed wire encasing it. The other method involved the barbed wire being attached to wooden posts using a U-shaped staple (Figure 4-10). The barbed wire represents fragments of old property lines, more than likely those which stood during the leasing of the property by TPWD in 1971.

Another common artifact at the park includes glass bottles. When glass bottles or fragments of glass bottles were located on the surface, shovel tests were excavated in the vicinity in order to determine whether additional deposits were also present. In most cases where glass bottles were found modern trash was also present. Modern trash included beer cans, soda bottles, motor boat oil containers, and park debris, including wooden beams and concrete pipes (Figure 4-11). It was not uncommon to find glass bottles and fragments alongside modern day refuse in areas where inundation frequently occurs or in areas where park debris was systematically dumped. Glass bottles typically included CocaCola, Dr. Pepper, and Pearl bottles common to the 1960s-1970s.

Other artifacts discovered within the park boundaries include metal refuse. This typically includes deteriorating metal buckets and cans. Other metal artifacts include those found by park visitors (Figure 4-12). These artifacts are now stored at the park maintenance barn after they were confiscated by park staff. The original location of these artifacts is unknown.

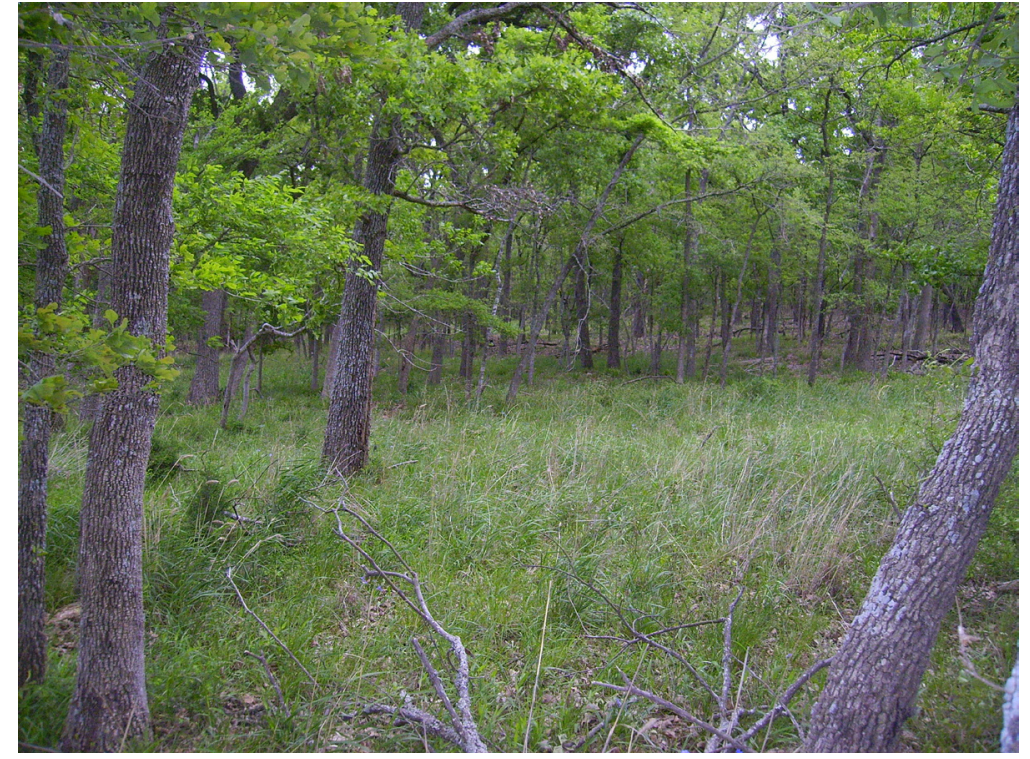

Figure 4-8. Terrain common in the northern portion of the park. 
The least common artifact seen at Fairfield Lake State Park includes pottery sherds and bricks. The pottery sherds identified were all located along roads and on top of pipelines, near an identified site in areas previously disturbed by park construction. Brick refuse was also present within the park boundaries. In all cases, the bricks appeared to be out of context. They appeared to be out of context due to the low frequency and their location, as is the case with the bricks in a small drainage near the Springfield Camping area (Figure 4-13).

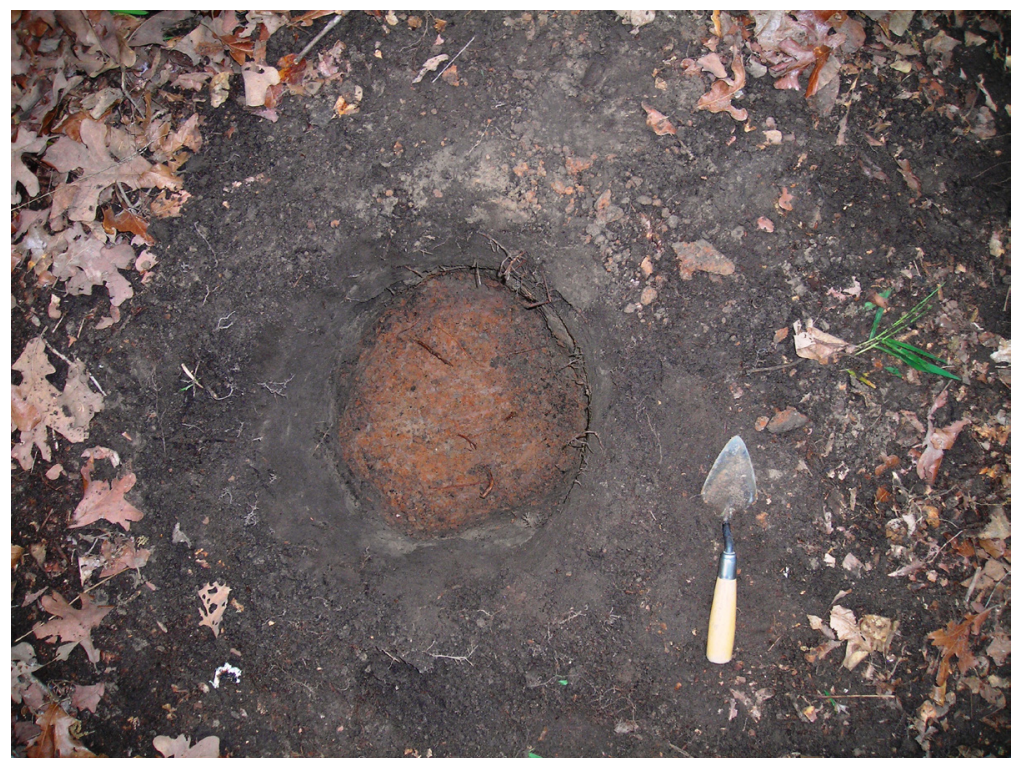

Figure 4-9. ST 210 located in the northern portion of the park. Note the clay present just below the surface.
When isolated finds were located shovel tests were excavated in the immediate vicinity. The following shovel tests were all excavated in response to isolated finds or other surface features such as agricultural fields and historic roads. Detailed descriptions of these shovel tests are presented in Appendix A.
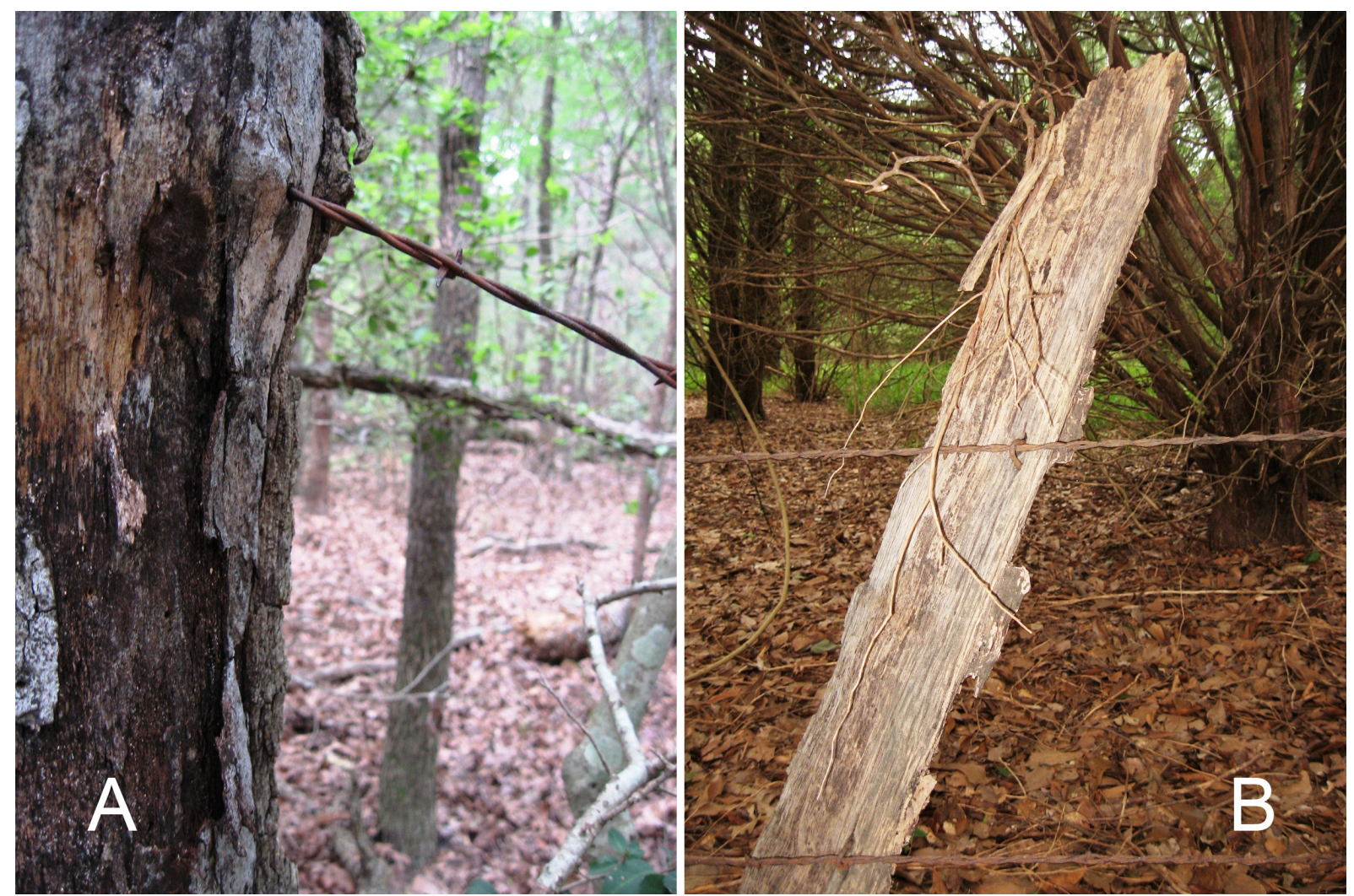

Figure 4-10. Barbed wire: (A) Encased within the tree trunk; (B) Attached to a wooden post using a U-shaped staple. 


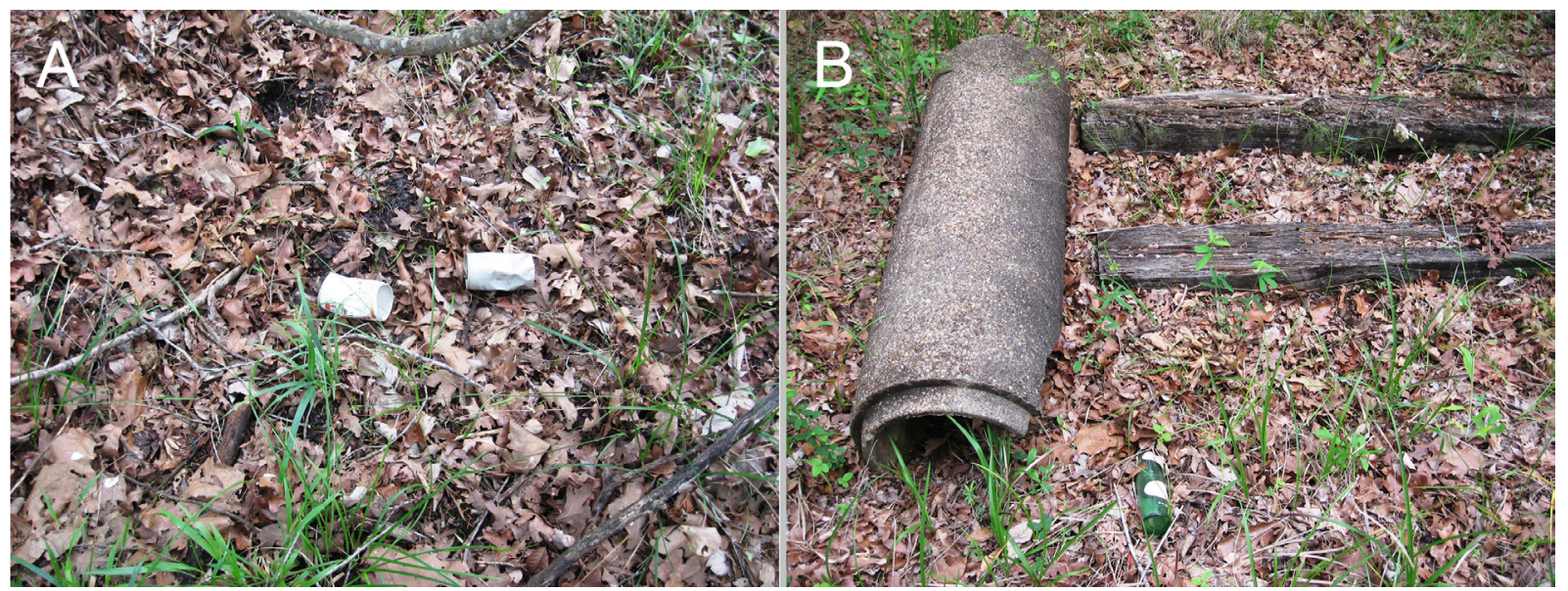

Figure 4-11. Modern trash: (A) Beer cans; (B) Park maintenance debris.
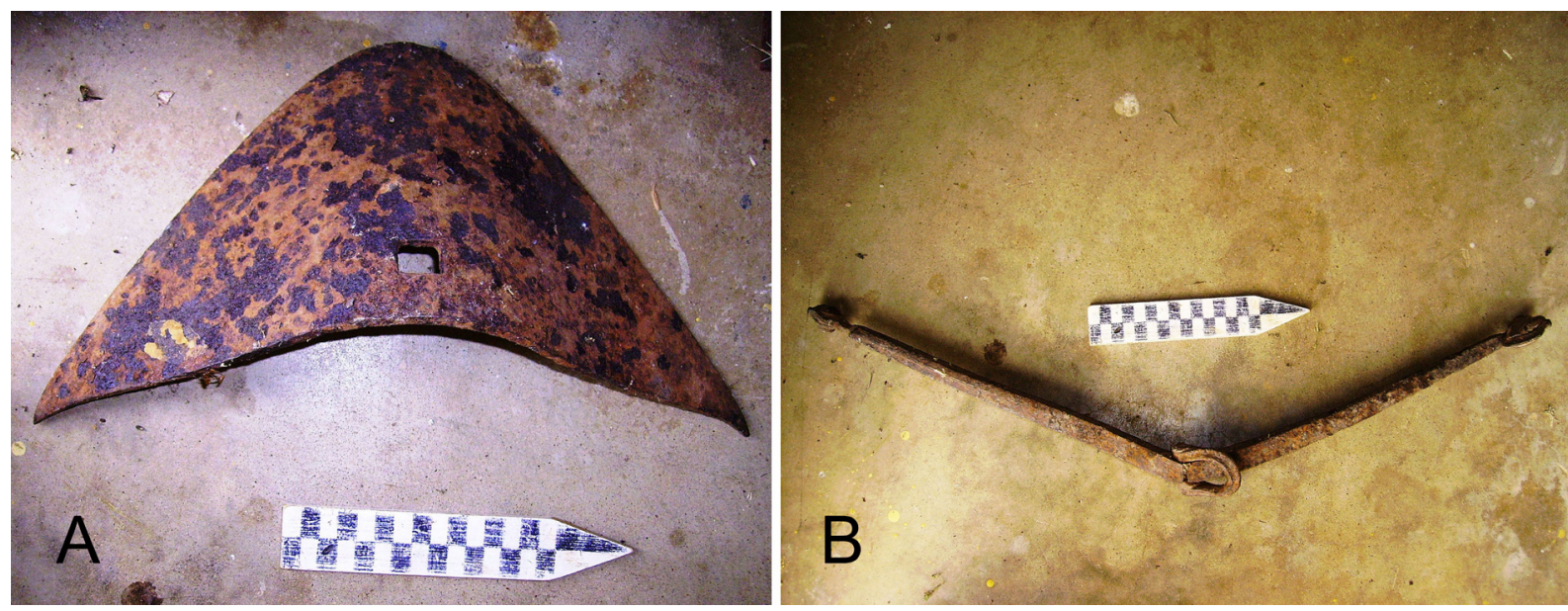

Figure 4-12. Historic metal objects confiscated by TPWD: (A) Historic hoe head; (B) Unknown historic metal object.

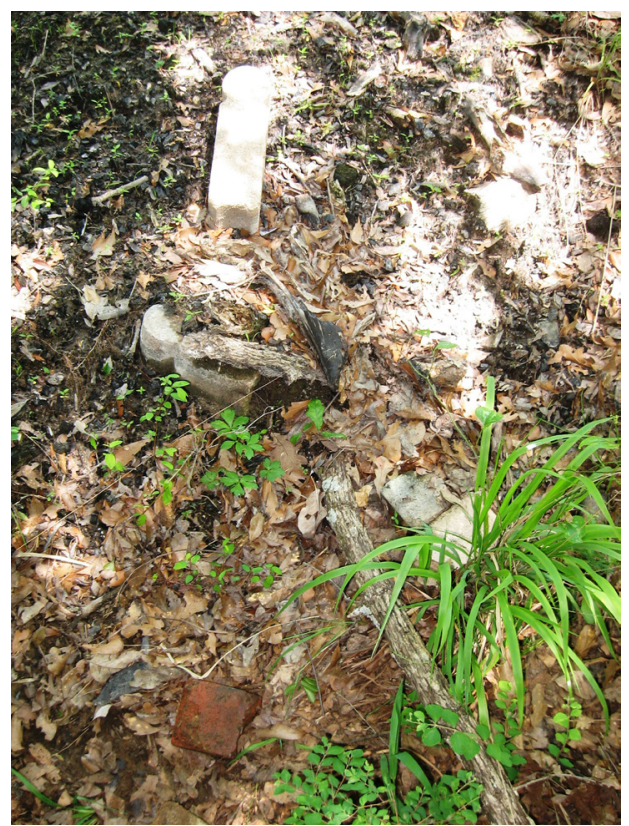

Figure 4-13. Cluster of bricks located in the Springfield Camping area.

\section{Shovel Tests No. 35 and 38}

Shovel tests No. 35 and 38 were excavated in response to three glass bottles located on the surface. The glass bottles were located behind the park's maintenance barn off an old historic wagon trail (Figure 4-14). The terrain is relatively flat, inclining slightly to the north. Mixed hardwoods, shrubs, and short to tall grasses are present in this area. The three glass bottles were found together along with a rubber shoe sole (Figure 4-15). Two of the three bottles were able to be dated based on their makers mark. A specific date could not be obtained for either bottle, but the date of manufacture ranges from 1911-1953 or later (Toulouse 1971). Shovel tests No. 35 and No. 38 yielded no additional artifacts. 


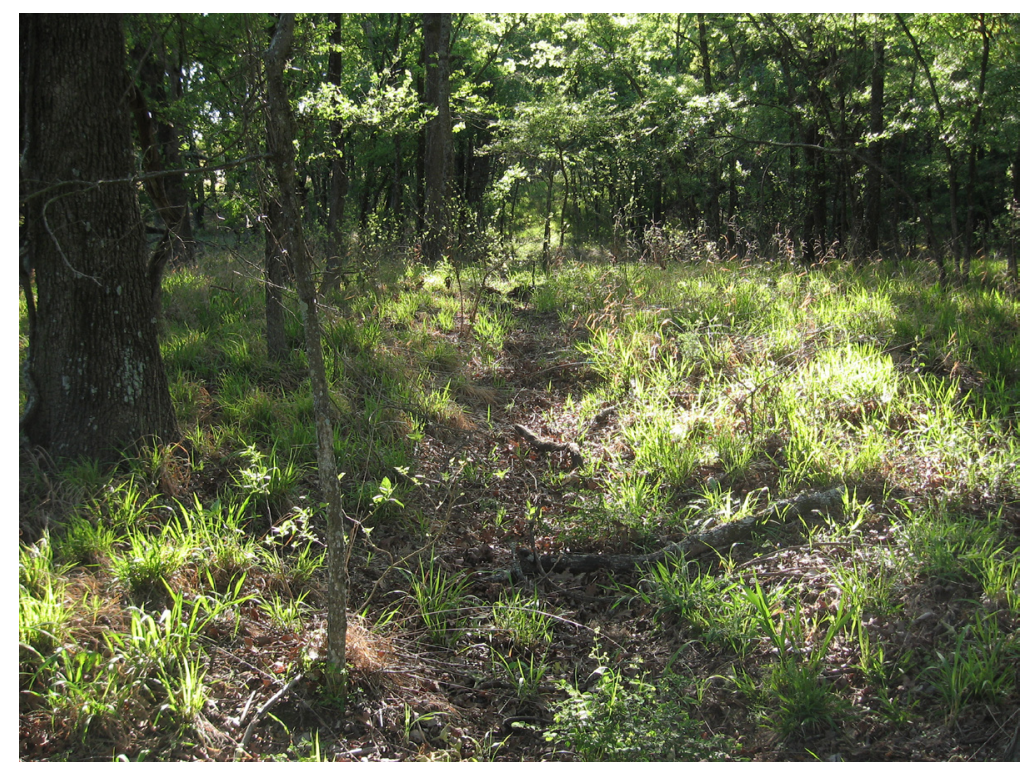

Figure 4-14. Possible historic road located northwest of the maintenance barn; photographed facing east.

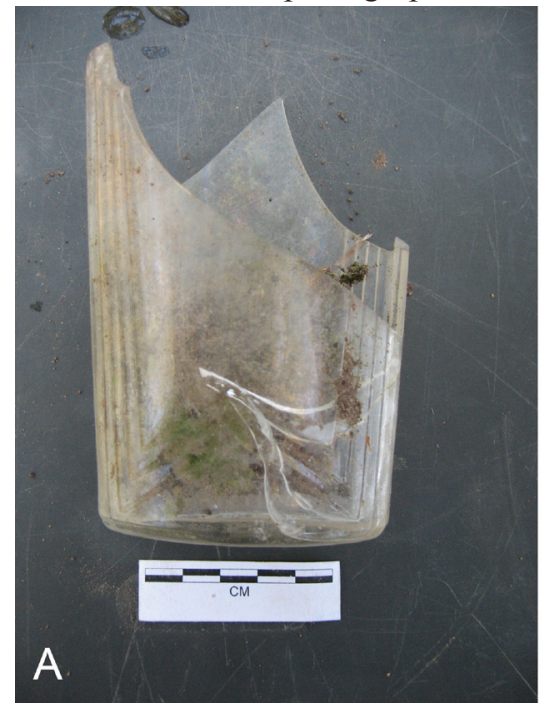

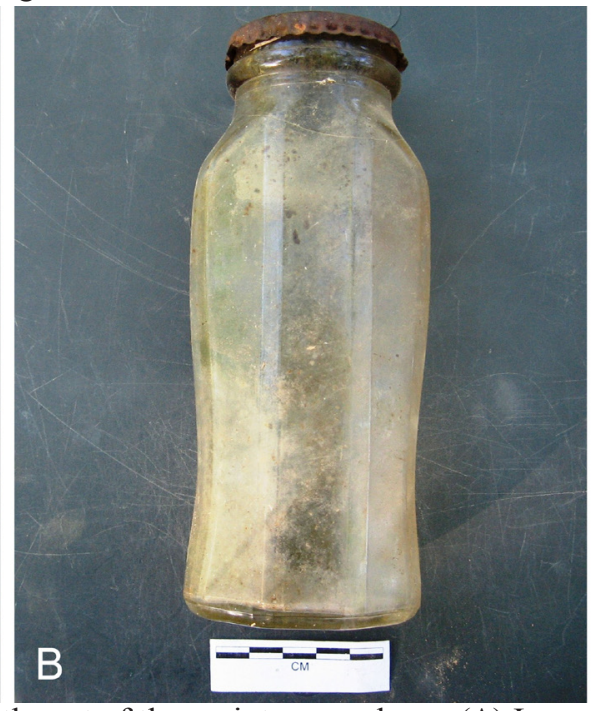

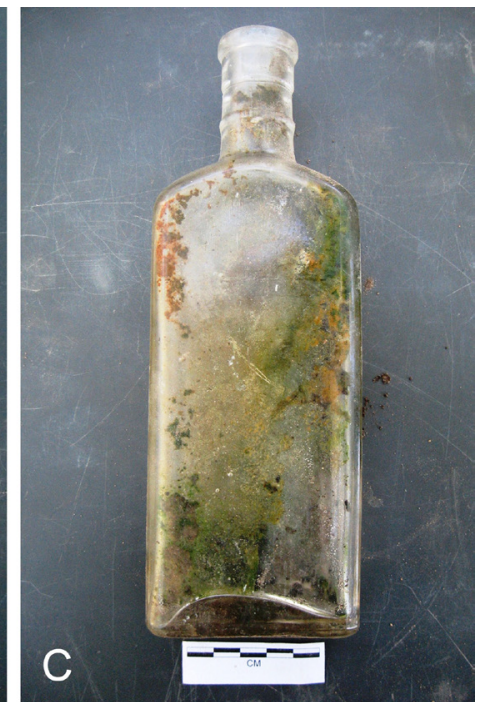

Figure 4-15. Glass bottles located northwest of the maintenance barn: (A) Incomplete glass cup, date unknown; (B) Complete glass bottle (1932 to 1953 or later); (C) Complete glass bottle (1911-or later).

\section{Shovel Test No. 42}

Shovel test No. 42 is located to the south of the intersection of Little Brown Creek and the Park Road. The terrain slopes west towards the park road and is composed of mixed hardwoods, shrubs, and short grasses. An iron ore sphere was located at 15 cbms (Figure 4-16). This object is a natural concretion that is in the shape of a sphere and may be commonly mistaken as a marble. The shovel test was terminated at 50 cbms after reaching dense clay and a concentration of hematite and petrified wood.

\section{Shovel Test No. 109}

Shovel test No. 109 was excavated in response to a wooden board fastened to a tree (Figure 4-17) in close proximity to the lake line. No artifacts were present on the surface nor were there any markings present on the board. A slight depression is present within the vicinity of the shovel 


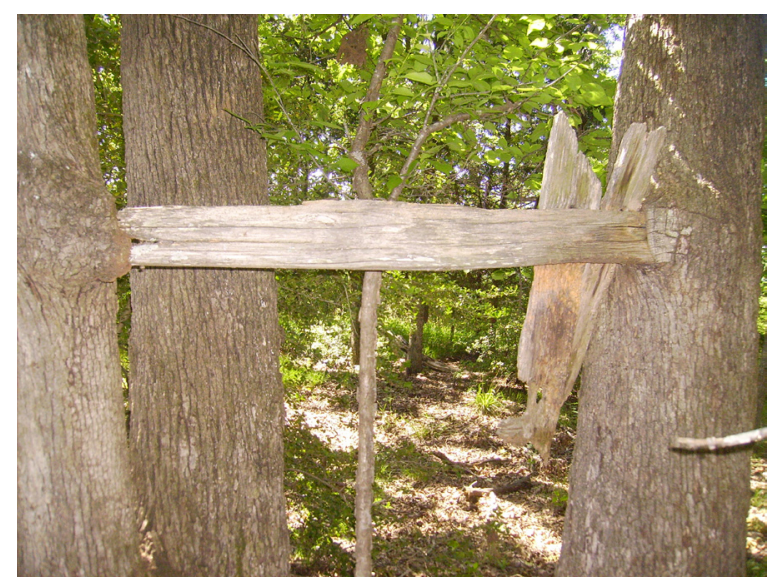

Figure 4-17. Wooden board fastened to a tree near ST 109.

test running in an easterly direction towards lake. The terrain is relatively flat and consists of mixed hardwoods and tall grasses. The shovel test produced negative results.

\section{Shovel Test No. 179}

Shovel test No. 179 is located $200 \mathrm{ft}$. from a 1950s abandoned Buick car in the primitive camping area (Figure 4-18). Possible agricultural fields are present to the south and to the north (Figure 4-19). The terrain consists of tall grasses and mixed hardwoods. The shovel test produced negative results and no artifacts were found in the vicinity of the vehicle. The shovel test was closed after encountering clay at $80 \mathrm{cmbs}$.

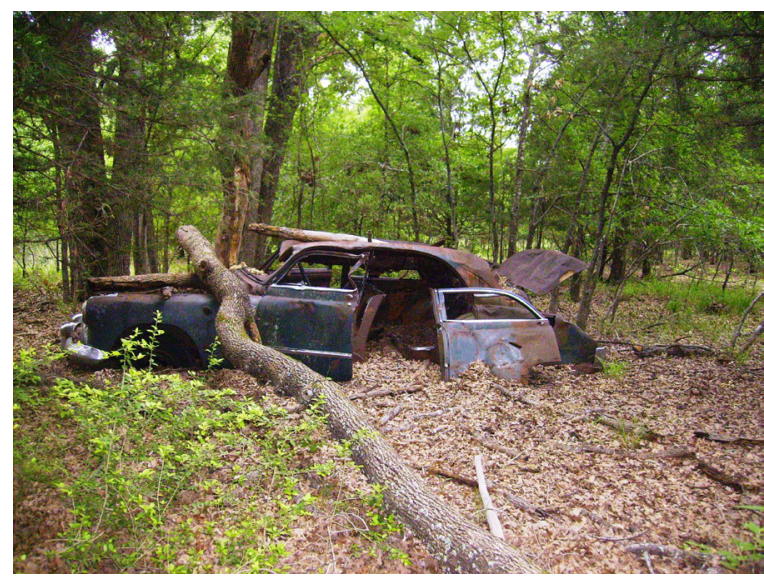

Figure 4-18. Abandoned Buick vehicle.

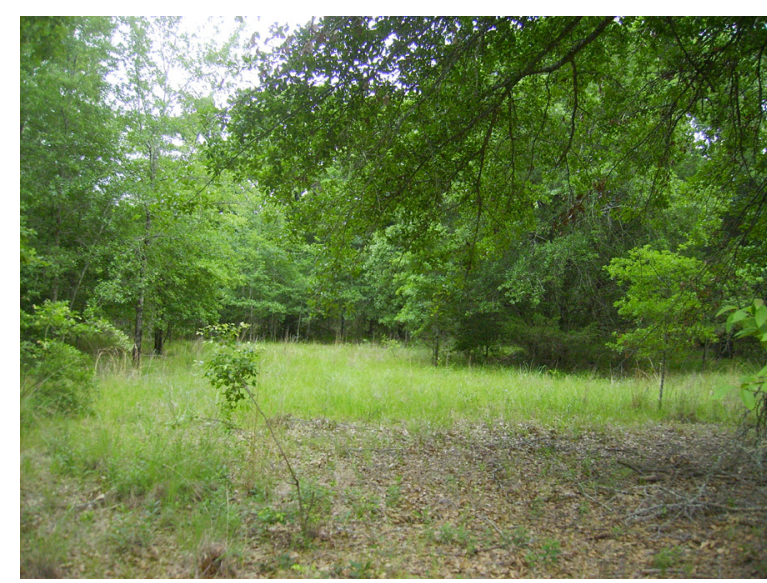

Figure 4-19. Possible agricultural field located in the northwestern portion of the park near the primitive camping area.

\section{Shovel Test No. 196}

Shovel test No. 196 is located in the northwestern portion of the park in between two creek beds that run east to west. The park boundary and a pipeline are located 50 feet uphill from the shovel test. Terrain slopes from west to east and contains mixed hardwoods. The shovel test was excavated in response to a fractured quartz nodule that could have been a prehistoric artifact located on the surface (Figure 4-20). A thorough surface survey was made of this locale before the shovel test was excavated. The surface survey and the shovel test produced negative results with the presence of clay at the surface (Figure 4-21). The quartz nodule showed

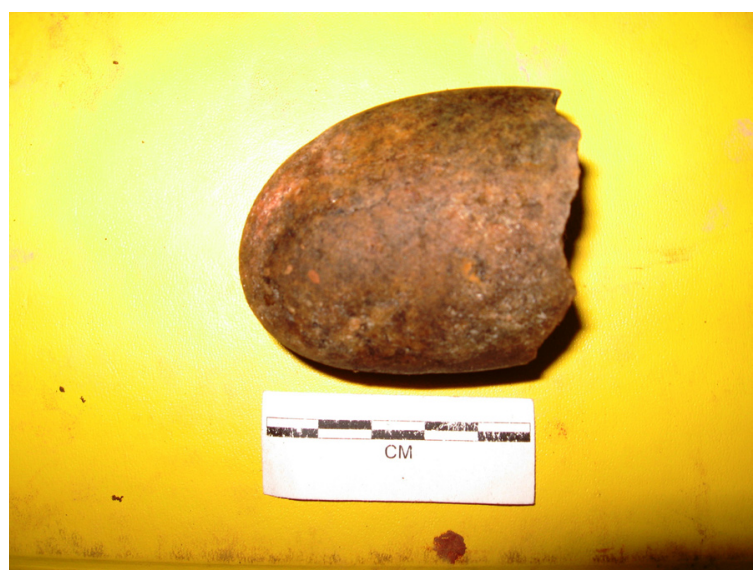

Figure 4-20. Fractured quartz nodule. 


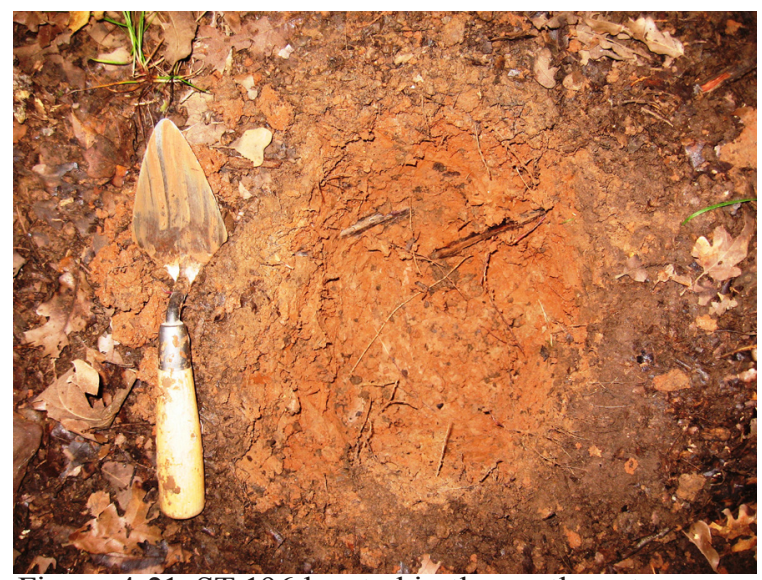

Figure 4-21. ST 196 located in the northwestern portion of the park. Note the presence of clay at the surface.

no definitive signs of human modification, and no site was recorded here.

\section{Shovel Test No. 204}

Shovel test No. 204 was excavated due to the presence of two metal buckets along a barbed wire fence in the northwestern portion of the park (Figure 4-22). The shovel test is located uphill from the lake and the terrain consists of mixed hardwoods, short grasses, and shrubs. The shovel test produced negative results, reaching clay at $10 \mathrm{cmbs}$ (Figure 4-23). The shovel test and metal buckets are located 68 meters downhill on a gradual incline from site 41FT470, which

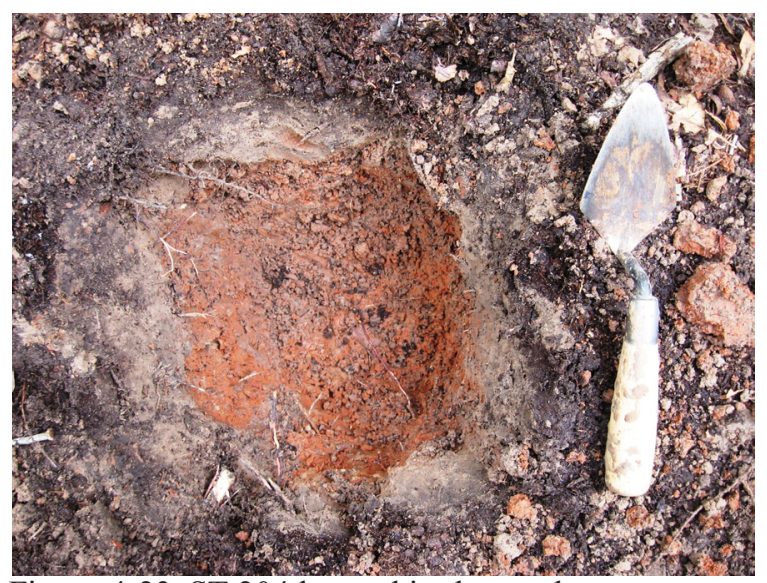

Figure 4-23. ST 204 located in the northwestern portion of the park. Note the presence of clay at 10 cmbs.

is classified as a historic structure. The metal artifacts are more than likely associated with site 41FT470.

\section{Shovel Test No. 211 and 215}

Shovel tests No. 22, 211, and 215 were excavated due to the presence of park debris. The debris and shovel tests are located to the southeast of the park road. A small drainage system runs north to south approximately seven meters to the northeast of the park debris. The terrain consists of mixed hardwoods and short grasses. The modern park debris consisted of glass bottles, wooden beams, concrete cylinders,
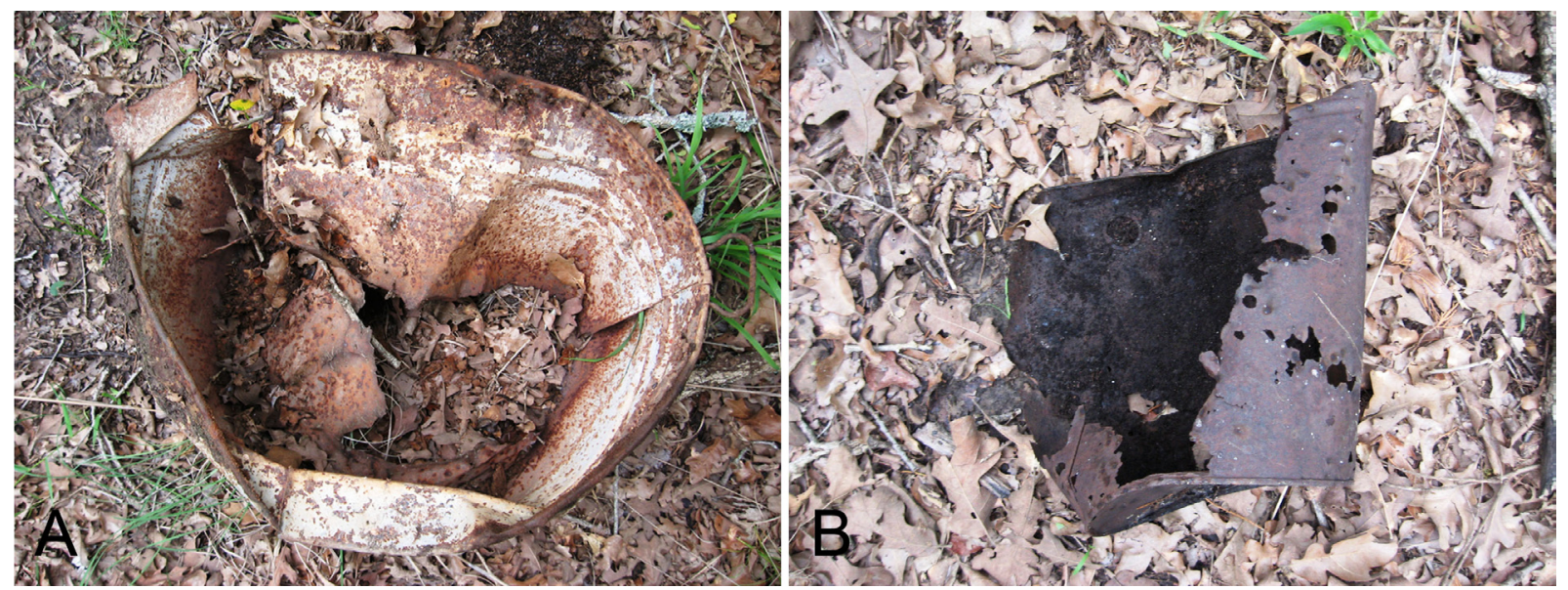

Figure 4-22. Metal buckets located 68 meters downhill from site 41FT470. 

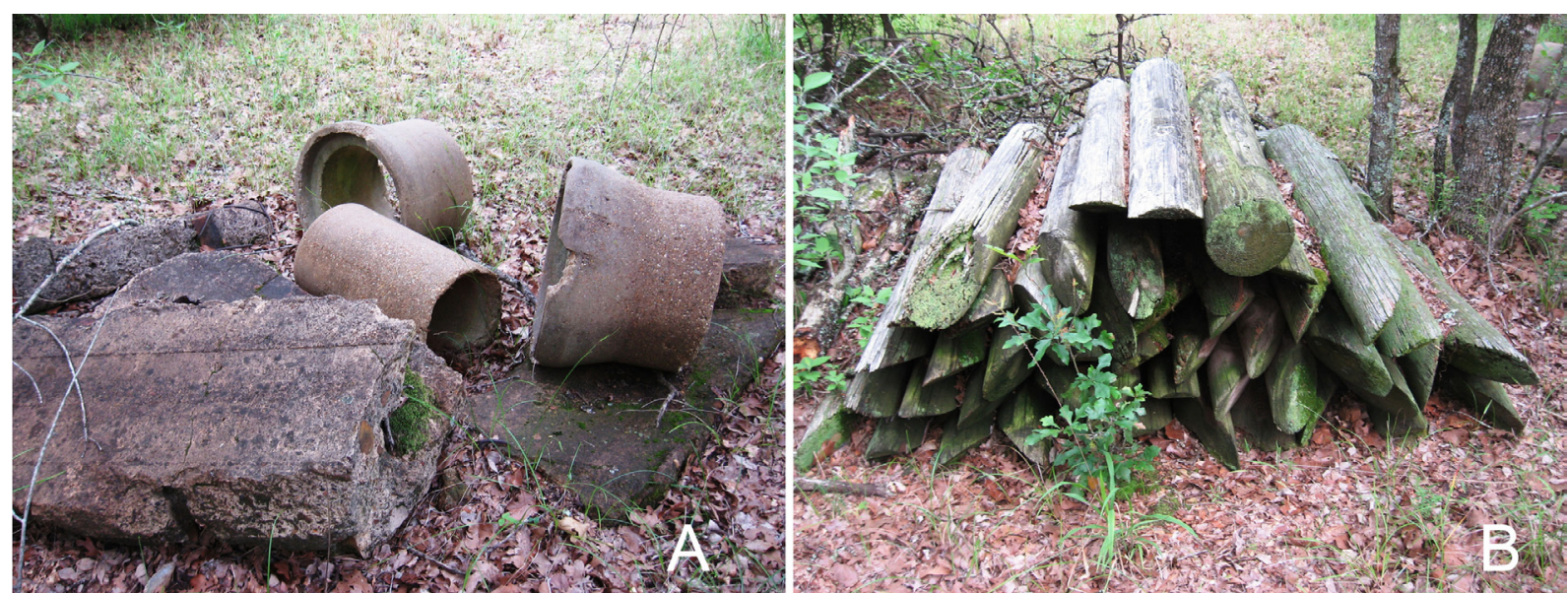

Figure 4-24. Modern park debris: (A) Concrete pipes; (B) Wooden posts.

and metal fragments (Figure 4-24). The shovel tests produced negative results and after a brief analysis of the debris it was concluded that the artifacts were modern and associated with park construction clean-up.

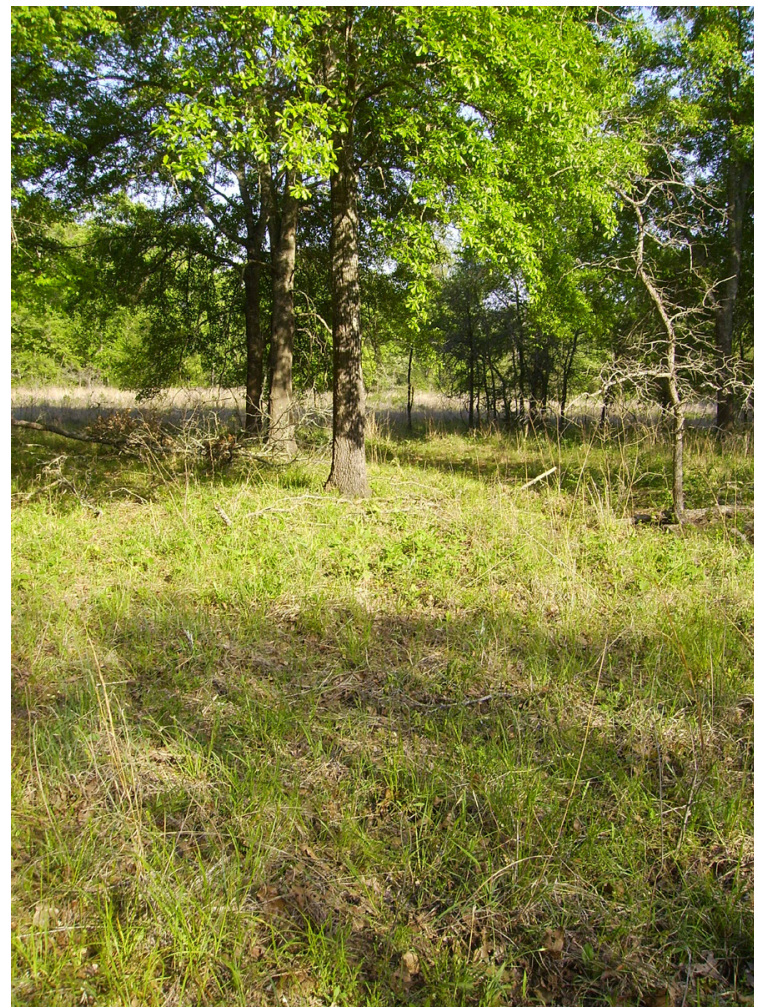

Figure 4-25. Possible large abandoned agricultural field.

\section{Shovel Tests No. 31 and 36}

Shovel tests No. 31 and 36 were excavated in response to what appears to be a large abandoned agricultural field (Figure 4-25). The agricultural field is located about 400 meters to the east of park headquarters and is north of the park road. Little Brown Creek runs along the eastern boundary of the agricultural fields. To the northeast of the agricultural field a low lying area exists, which appears to be frequently inundated (Figure 4-26). Both shovel tests and a visual survey of the area produced negative results.

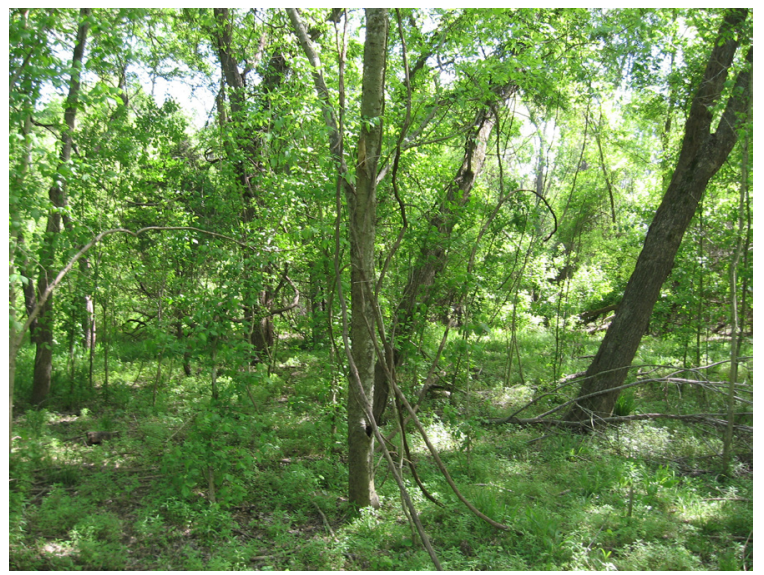

Figure 4-26. Inundated area located to the northeast of the large abandoned agricultural field. 

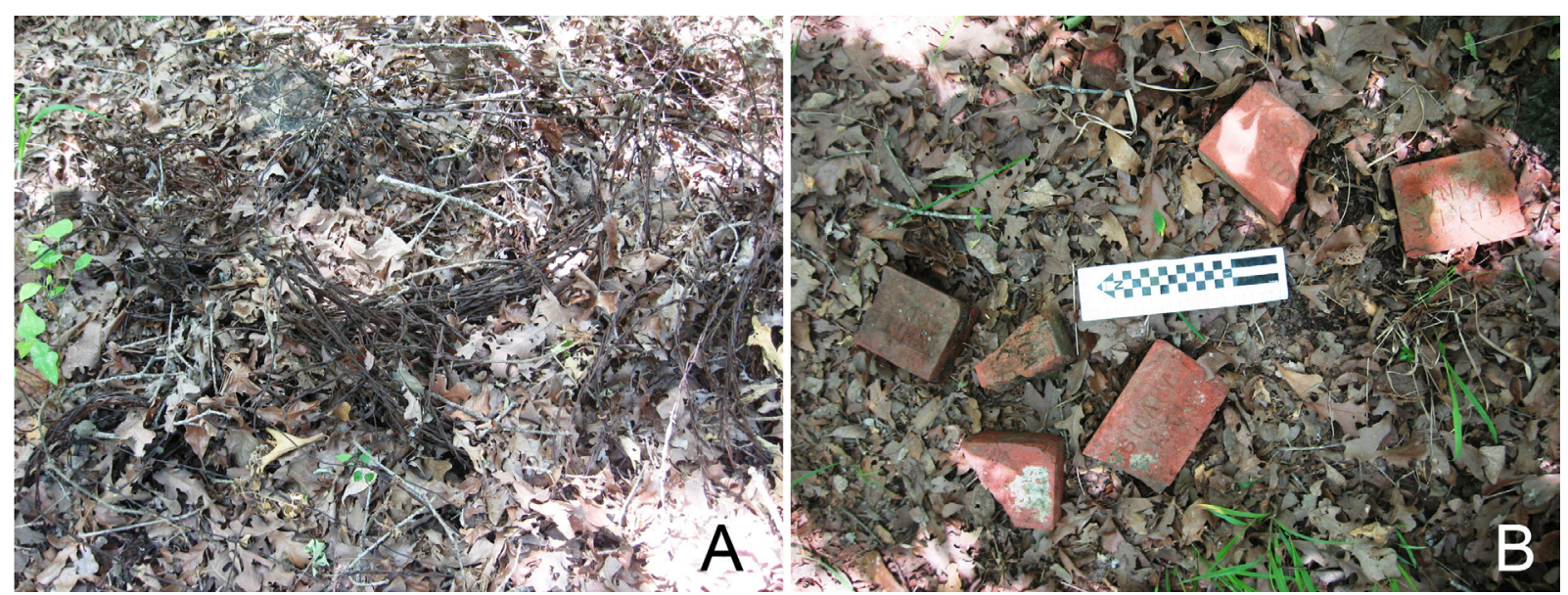

Figure 4-27. Isolated finds: (A) Bound barbed wire; (B) Brick scatter.

\section{Shovel Tests No. 114, 118, and 107}

Shovel tests No. 114, 118, and 107 were excavated due to the presence of a brick scatter and a few bundles of barbed wire (Figure 4-27). A historic road, running north to south is located to the east of the shovel tests (Figure 4-28). All shovel tests produced negative results.

The barbed wire was bound together with modern wire ties and the low frequency of bricks suggests that the artifacts present were removed from their original context and dumped at this location.

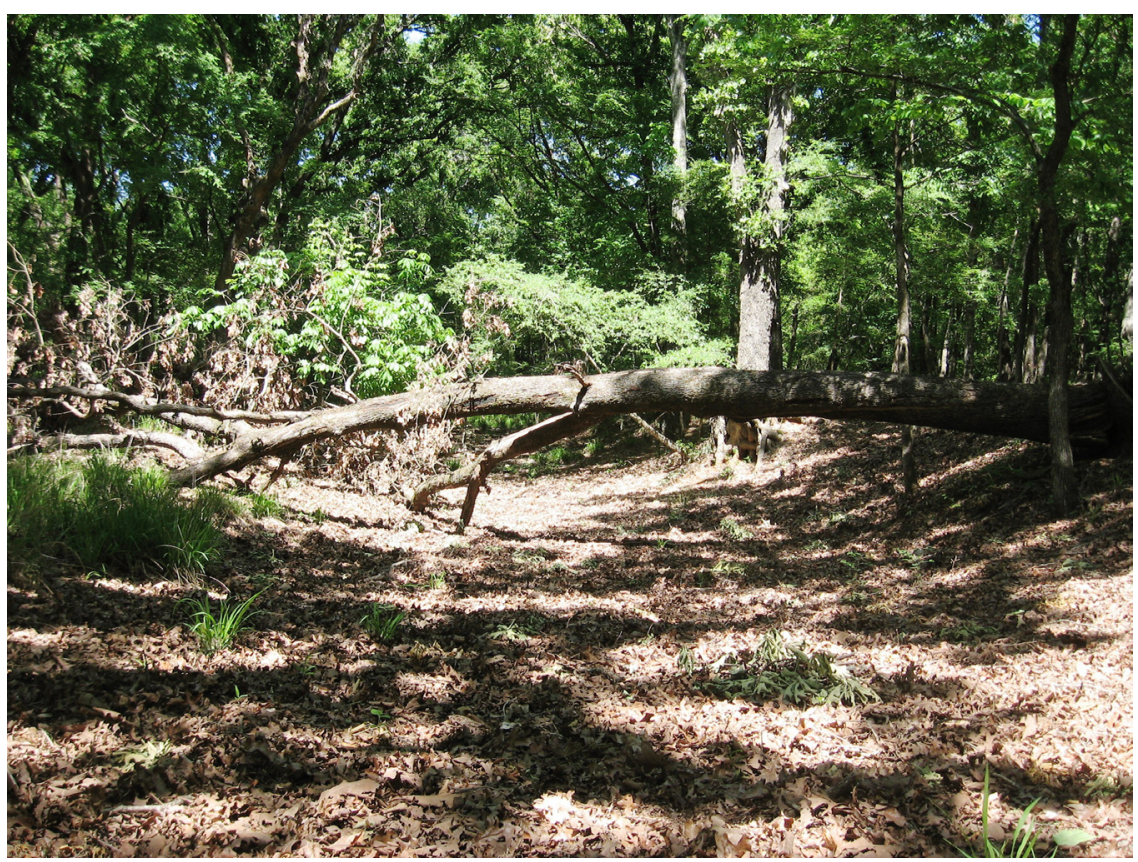

Figure 4-28. Possible historic road; photographed facing north. 


\title{
Chapter 5
}

\section{Conclusions And Recommendations}

\author{
by Jon C. Lohse, Julian A. Sitters, and David M. Yelacic
}

This project was conducted in order to provide a complete, systematic archaeological survey of the Fairfield Lake State Park. Previous survey projects (Yelacic et al. 2008) visited a total of 35 sites, 34 of which had been previously recorded, representing historic and prehistoric occupation. However, it remained uncertain that previous projects had covered the entire park area, or had only visited locales identified as high probability areas. The current effort was preceded by an archival search for historic buildings, and files in the Freestone County Clerk's Office were checked to determine whether the abandoned cemetery, 41FT630, had ever been platted. Following the review of historical sources, field work consisting of pedestrian survey and shovel testing of the entire park, excluding recorded sites and highly disturbed areas, was conducted. Two hundred fifteen shovel tests were excavated during this project. No new sites were located, and all cultural materials that were observed during the survey are believed to reflect modern and recent usage of the park.

Based on the results of this project, CAS recommends that TPWD consider the list of sites presented in Yelacic et al. (2008) to be complete. Detailed recommendations regarding each site's eligibility for listing to the NRHP and worthiness for designation as a SAL presented in that report should be followed in the event of future developments and impacts. For convenience, the list of recorded sites and their assigned management priority is appended to this report in Appendix B. Briefly, Level 1 sites are considered eligible for listing to the NRHP and/or being designated as SALs and should be avoided to the degree possible or feasible in the context of the proposed development. If these sites cannot be avoided, CAS recommends that TPWD conduct additional archaeological investigations and, in the case of historic sites, archival research to mitigate the loss of important cultural information that these sites contain. In the event that Level 2 sites cannot be avoided and will be impacted by future developments, CAS recommends that TPWD conduct additional archaeological and/or archival research to finalize assessments about the potential significance of these sites. This research should focus on assessing whether these sites meet any of the significance or worthiness criteria set forth in the NHPA or the Texas Antiquities Code. Based on the results of this work, additional research may or may not be warranted. Level 3 sites are considered to have very little to no research potential, but are of unknown eligibility for designation as SALs or nomination to the NRHP. The THC should review these sites in the event of future impacts. Level 4 sites are not considered eligible for listing to the NRHP or worthy of being designated as SALs. If future developments are proposed that will impact Level 4 sites, CAS recommends that TPWD be granted regulatory clearance to proceed with those activities without further consideration for any potential loss of information that may result from that development. 
Regarding the abandoned cemetery, site 41FT630, CAS was unable to find any evidence that it has ever been legally platted at the Freestone County Clerk's Office. Abandoned cemeteries in Texas are described and regulated in Chapter 711, Sections 711.010 and 711.011 of the State of Texas Health and Safety Code. Section 711.011 (a) states that "a person who discovers an unknown or abandoned cemetery shall file notice of the cemetery with the county clerk of the county in which the cemetery is located. The notice must contain a legal description of the land on which the unknown or abandoned cemetery was found and describe the approximate location of the cemetery and the evidence of the cemetery that was discovered" (emphasis added). CAS interprets the term "shall" to mean that filing of these cemeteries is required under State law.

Based on the negative finds of CAS's investigations of current records at the Freestone County Clerk's office, CAS recommends that site 41FT630 be legally surveyed and reported to the Freestone County Clerk's office in Fairfield. At present, the precise boundaries of this cemetery are uncertain; some depressions are evident in a loose cluster near the single headstone, but at least one isolated depression is also visible on the opposite side of the park road that bisects the cemetery (see site description in Yelacic et al. 2008:72-74). Accordingly, before the legal description of the cemetery is filed, CAS recommends that TPWD conduct archaeological survey of this site in order to search for additional unmarked graves. This work should employ multiple techniques to search for unmarked burials, including but not specifically limited to non-intrusive techniques such as Ground Penetrating Radar (GPR) survey with a magnetometer or, minimally, hand-held magnetic detector. Additional efforts should include systematic shovel testing throughout the area thought to possibly contain unmarked graves. Systematic shovel testing will allow for greater control over the depth of the excavation and the amount of surface area disturbed when compared to mechanical ground scraping. Upon the discovery of coffin furniture, human remains, and other related funerary objects, it is recommended that vertical excavation will cease and horizontal excavations will begin to confirm the presence of a grave. CAS recommends that more intrusive techniques such as mechanical ground scraping be considered inappropriate to the current use of this area as a recreational State Park. These activities are also liable to bring additional unwanted attention to the cemetery area, which is currently unfenced and unmarked.

Limited available archival and historical information about the cemetery's sole named interment, Mrs. Easter Miles, indicates that both she and her husband, Mr. Bob Miles, were of African American descent. Marriage records reveal that they were wed in 1868, not long after post-bellum emancipation. Mrs. Miles's maiden name, Strain, is the same as one of the region's early prominent families, and it is very likely that she was a former slave who took or was given her owner's name. Together, this information makes it highly probable that the cemetery's other occupants are also of African American descent, and may have been slaves, freed slaves, or first generation descendants of freed slaves when they died. CAS accordingly recommends that an additional component of this effort include a series of oral interviews for the purpose of compiling a historical narrative about the descendant community, including many slaves and former slaves, who occupied this area and who may be interred in or were associated with this cemetery. These interviews should focus not only on descendant community members in Fairfield area, but also on prominent Anglo families who may be descended from 
the Strain family and who may have historical documents pertaining to the time period in question for Freestone County. 


\section{References Cited}

Bruseth, James E., and Randall W. Moir (editors)

1987 Introduction to the Richland Creek Archaeological Project: Environmental Background and Cultural Setting. In Richland Creek Archaeological Project, Vol. 1.

Pp. 1-6, Richland Creek Technical Series, Archaeology Research Program, Institute for the Study of Earth and Man, Southern Methodist University, Dallas.

d'Aigle, Robert P.

2006 Cultural Resource Management Intensive Archaeological Survey for a Proposed Gas Well Project by Apache Corporation, Tulsa, Oklahoma. Texas Antiquities Permit Number 4362. CRC Project: 050608. CRC, LLC, International Archaeology \& Ecology, Galveston.

Fields, Ross C.

1995 The Archaeology of the Post Oak Savannah of East Central Texas. Bulletin of the Texas Archaeological Society, Vol. 66:301-330, Austin.

2004 The Archaeology of the Post Oak Savannah of East-Central Texas. In The Prehistory of Texas, pp. 347-369, edited by Timothy K. Perttula, Texas A\&M University Press, College Station.

Fields, Ross C., Eloise F. Gadus, Amy C. Earls, Karen M. Gardner, L, Wayne Klement and Janet K. Wagner

1995 National Register Assessment of Prehistoric and Historic Sites in Area E at the Jewett Mine, Freestone County, Texas. Report of Investigations, Number 100, Prewitt and Associates, Inc., Austin.

Freestone County Clerk

1853-1883 Colored Marriage Records. Vol. 1-2:101.

Griffith, G.E., S.A. Bryce, J.M. Omernik, J.A. Comstock, A.C. Rogers, B. Harrison, S.L. Hatch, and D. Bezanson

2004 Ecoregions of Texas. U.S. Environmental Protection Agency, Corvallis.

Hagemejer, Harold

2001 The Barbed Wire Identification Encyclopedia, 3rd edition. Morris Publishing, Kearney..

Janak, Edward F., and Edward L. Griffin

2002 Soil Survey of Freestone County, Texas. United States Department of Agriculture, Natural Resources Conservation Service and Texas Agricultural Experiment Station, College Station. 
Jasinski, Laurie E

2002 Land of Great Promise: A History of Fairfield Lake State Park. Texas Parks and Wildlife Cultural Resources Program, Austin.

Leffler, John

1978 History of Freestone County, Texas. Freestone County Historical Commission, Fairfield.

Meltzer, David J., and Michael R. Bever

1995 Paleoindians of Texas: An Update on the Texas Clovis Fluted Point Survey. Bulletin of the Texas Archeological Society, Vol. 66:47-81, Austin.

Perttula, Timothy K.

1990 The Hurricane Hill Site (41HP106): Excavations at Copper Lake, Hopkins County, Texas. Second Draft. Contributions in Archaeology No. 9. Institute of Applied Sciences, University of North Texas, Denton.

1995 The Archeology of the Pineywoods and Post Oak Savanna of Northeast Texas. Bulletin of the Texas Archeological Society, Vol. 66:331-359, Austin.

2004 The Prehistoric and Caddoan Archeology of the Northeastern Texas Pineywoods. In The Prehistory of Texas, pp. 370-408, Texas A\&M University Press, College Station.

Price, G. R. Dennis

1983 Cultural Resources Survey of the TXO Eppes B No. 1 Well, Alternate 1, Located 694 Feet East and 50 Feet South of the Northwest Corner of the William Cooper Survey (A-135), in Fairfield Lake State Recreation Area, Freestone County, Texas. Texas Antiquities Permit Number 363. Heartfield, Price and Greene, Inc., Monroe, Louisiana.

Reed, Isaac and Jesse Koen Grant

N.D. Map of Freestone and Limestone County.

Richner, Jeffrey J.

1982 Tennessee Colony III. Archaeology Research Program, Department of Anthropology, Southern Methodist University, Dallas.

Richner, Jeffery J., and Joe T. Bagot

1978 A Reconnaissance Survey of the Trinity River Basin. Archaeology Research Program Research Report 113. Archaeology Research Program, Department of Anthropology, Southern Methodist University, Dallas.

Skinner, S. Alan

1983 An Archaeological Survey of the F. S. Hill \#1 Well Site, Freestone County, Texas. Texas Antiquities Permit Number 393. A R Consultants, Dallas. 
Story, Dee Ann

1965 The Archeology of Cedar Creek Reservoir, Henderson and Kaufman Counties, Texas. Bulletin of the Texas Archeological Society, Vol. 36:163-257, Austin.

Texas General Land Office, Austin

1905 Working Sketch in Freestone County, July 6th.

Texas State Highway Department

1948 General Highway Map. Freestone County, TX.

Tiemann, Marc A.

2003 Phase I Cultural Resources Survey for the Eppes Pipeline Right-of-Way within Fairfield Lake State Park, Freestone County, Texas. Texas Antiquities Permit Number 3263. Sphere 3 Environmental, Inc., Longview.

2004 Phase I Cultural Resources Survey for the Eppes No. 4 Well Site in Fairfield Lake State Park, Freestone County, Texas. Texas Antiquities Permit Number 3341. Sphere 3 Environmental, Inc., Longview.

Toulouse, Julian H.

1971 Bottle Makers and Their Marks. The Blackburn Press, Caldwell, New Jersey.

United States Geological Survey

1922 Army Corps of Engineer Historic Topographic. Fairfield, TX.

Wenke, Robert J.

1990 Patterns in Prehistory: Humankind's First Three Million Years, 3rd ed. Oxford University Press, Oxford.

Yelacic, David M., Gregory J. LaBudde, and Jon C. Lohse

2008 Cultural Resources Survey of Fairfield State Park, Freestone County, Texas. Archaeological Studies Report No. 15, Center for Archaeological Studies, Texas State University-San Marcos. 


\section{Appendix A}

\section{Fairfield Lake State Park - TPWD}

Shovel Test No. 31

Shovel Test

Profile

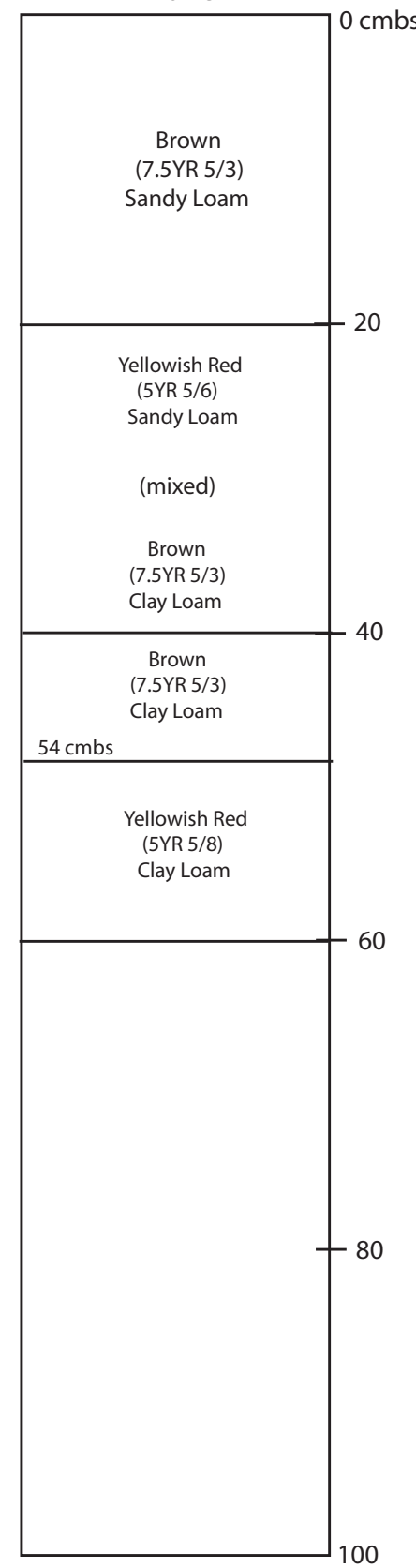

Artifacts

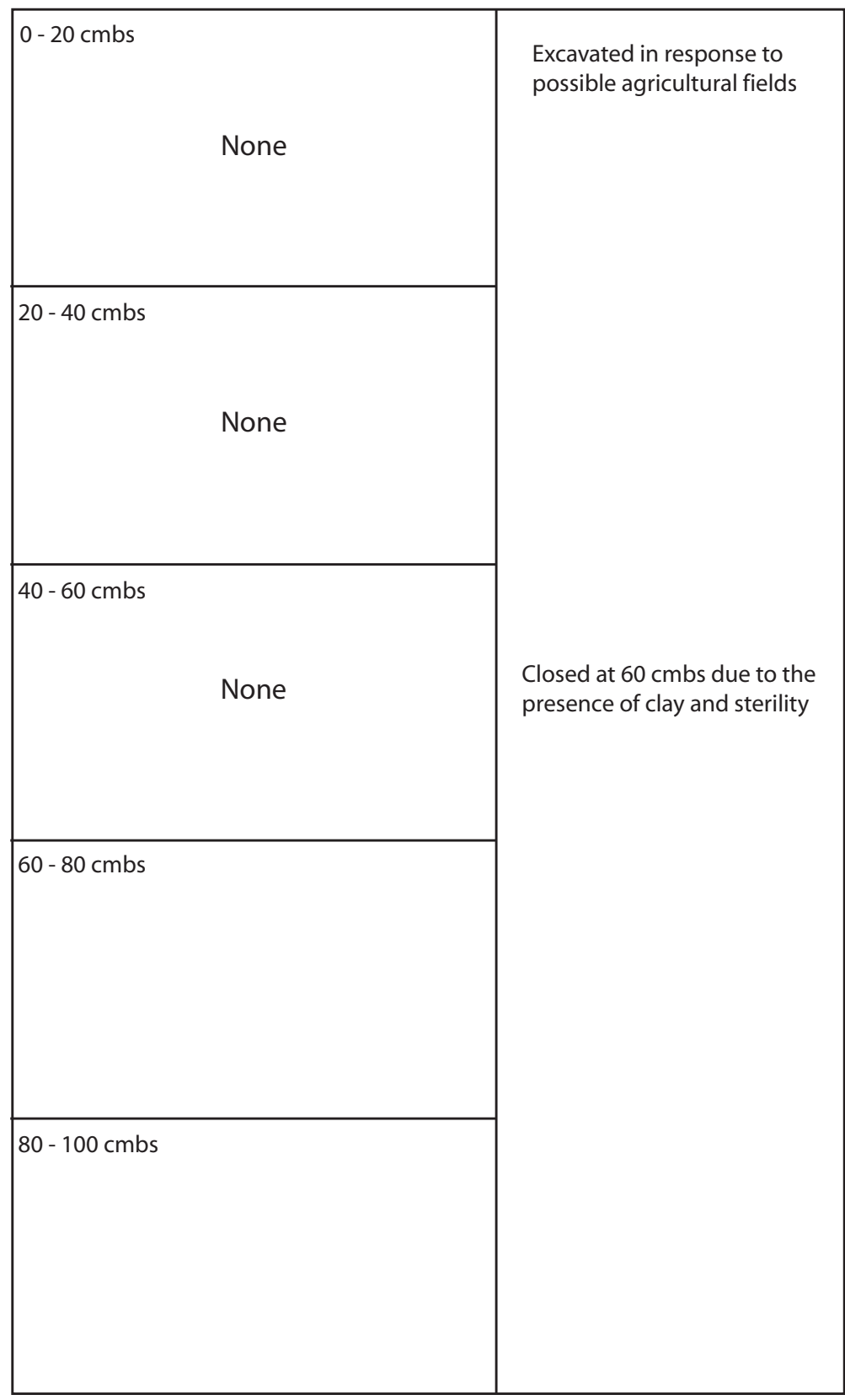




\section{Fairfield Lake State Park - TPWD \\ Shovel Test No. 35}

Shovel Test

Profile

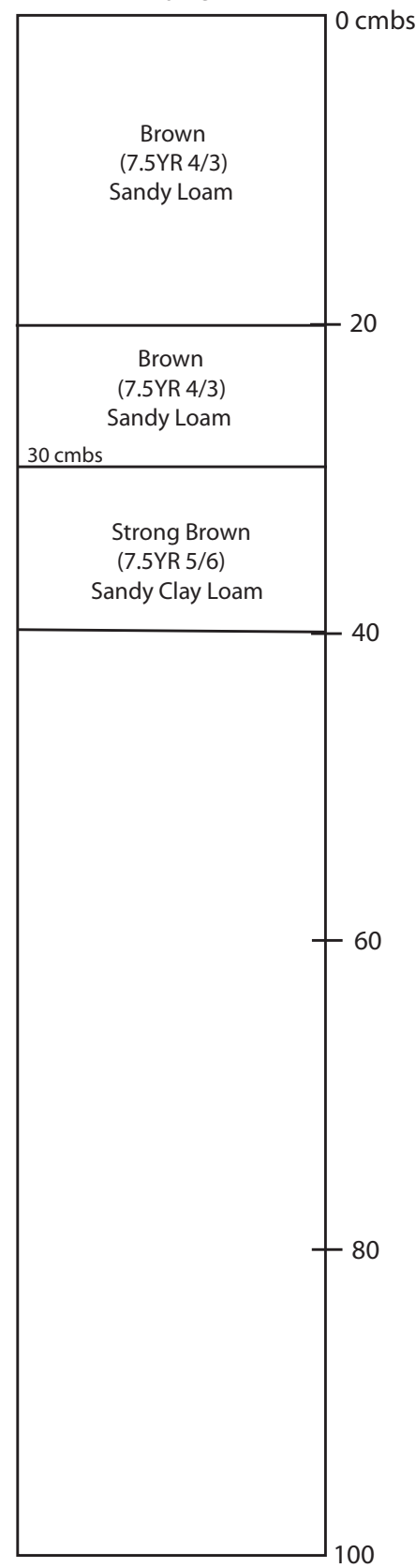

Artifacts

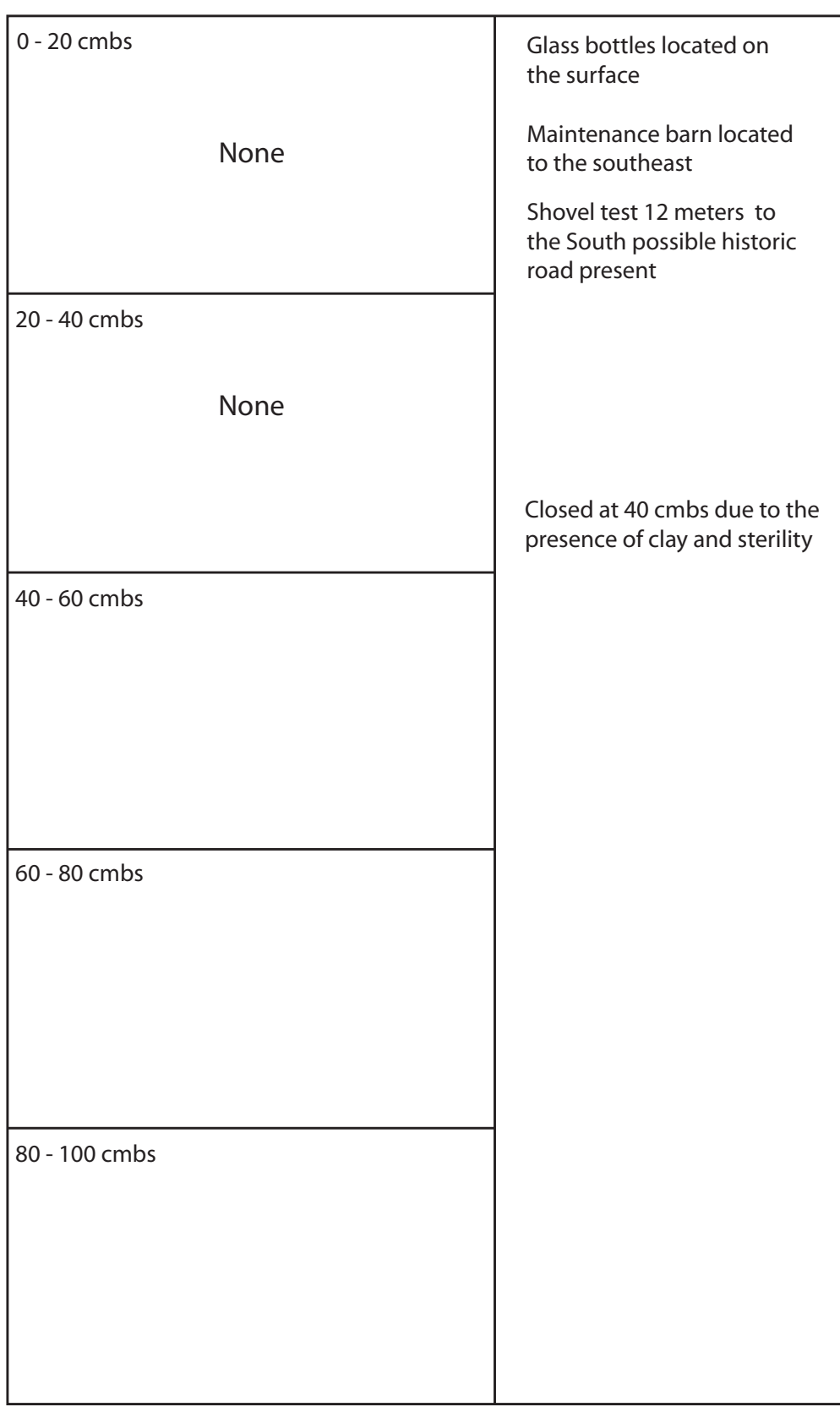




\section{Fairfield Lake State Park - TPWD}

Shovel Test No. 36

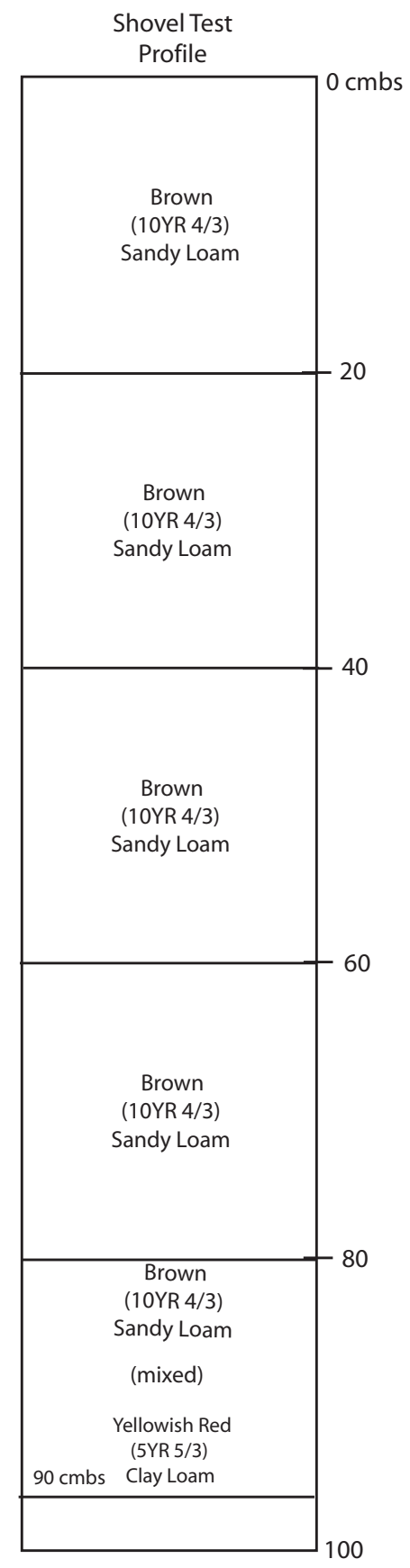

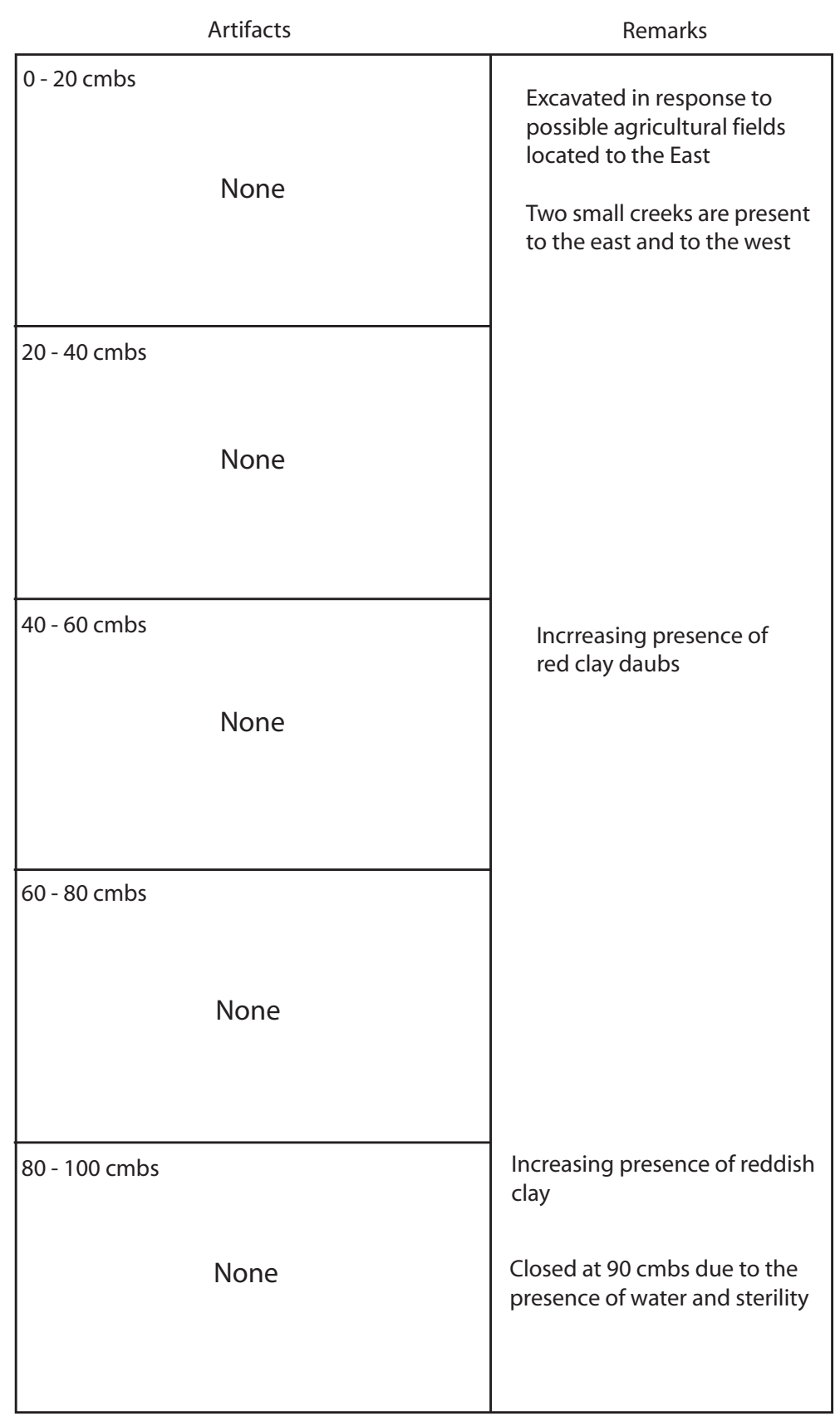


Fairfield Lake State Park - TPWD

Shovel Test No. 38

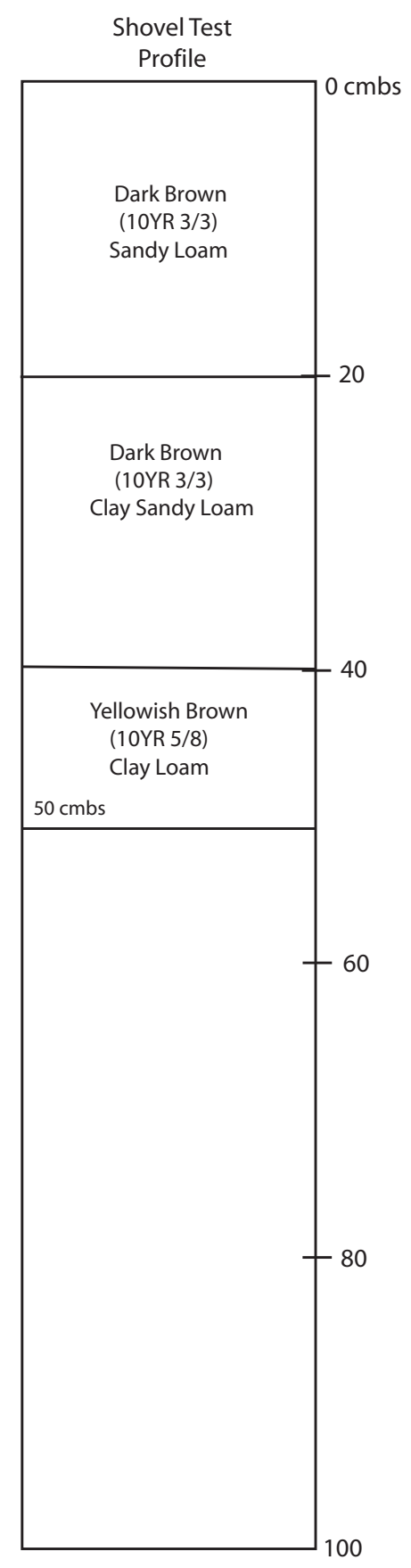

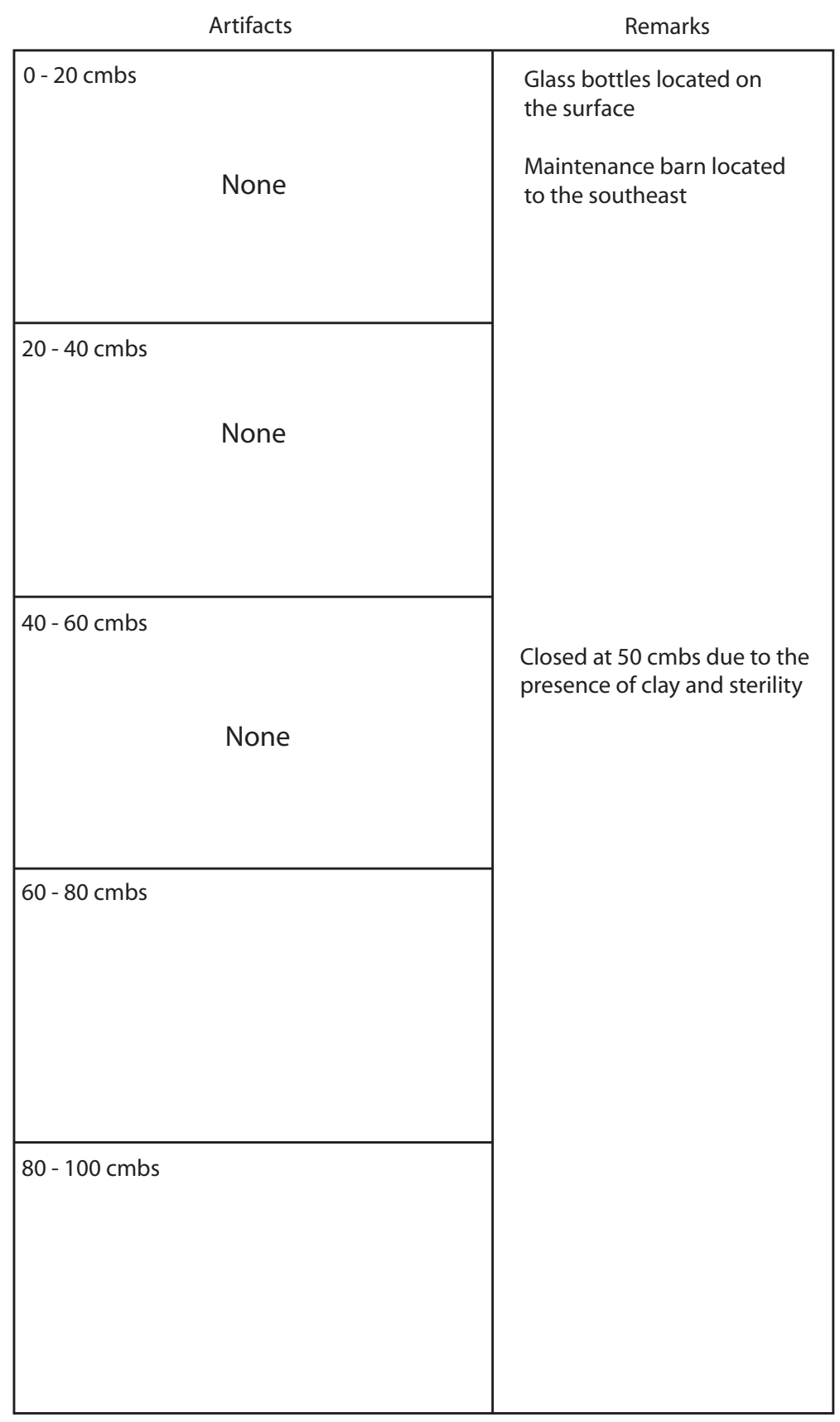




\section{Fairfield Lake State Park - TPWD \\ Shovel Test No. 42}

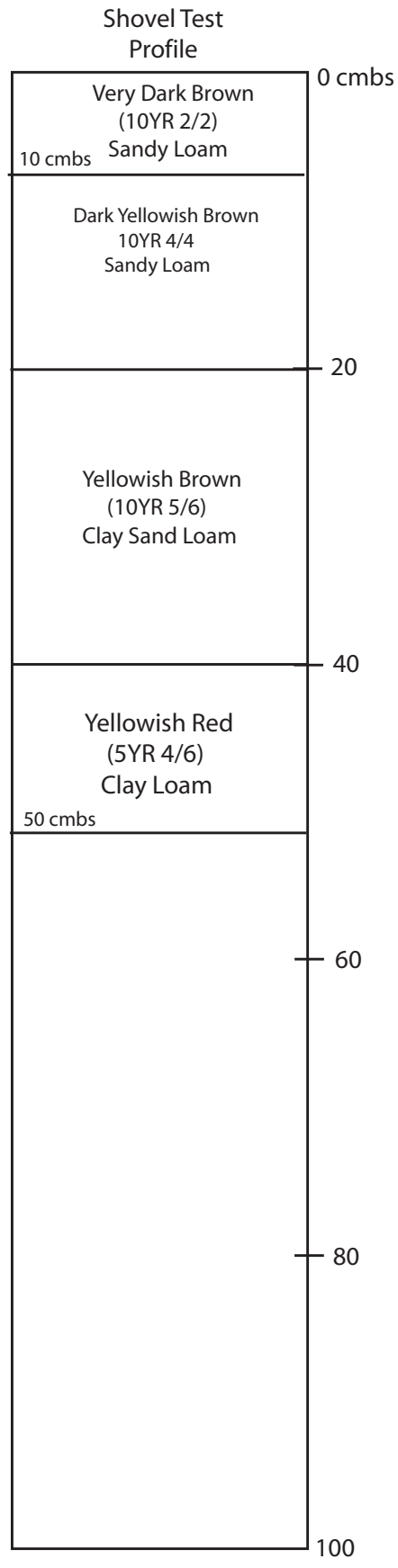

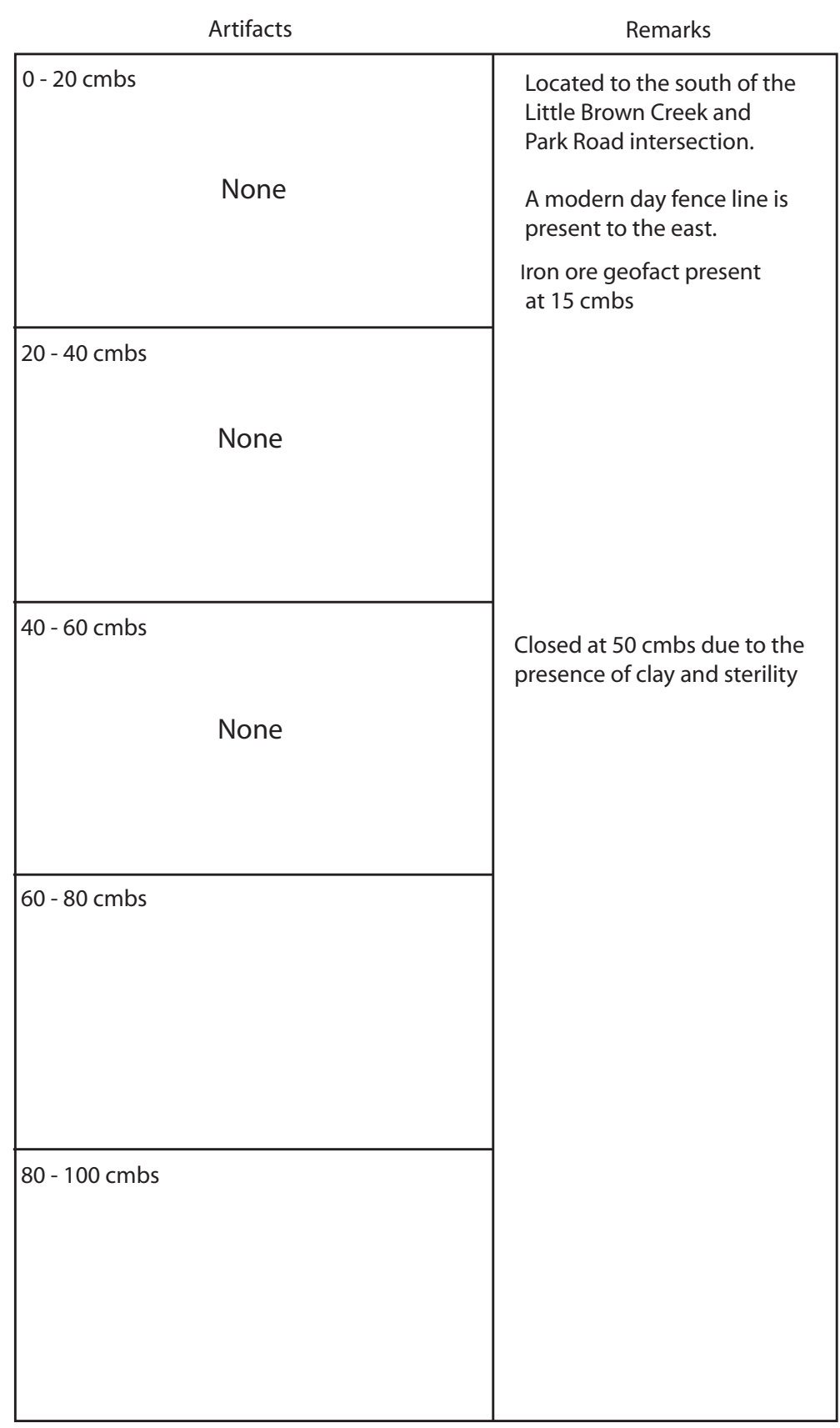


Fairfield Lake State Park - TPWD

Shovel Test No. 107

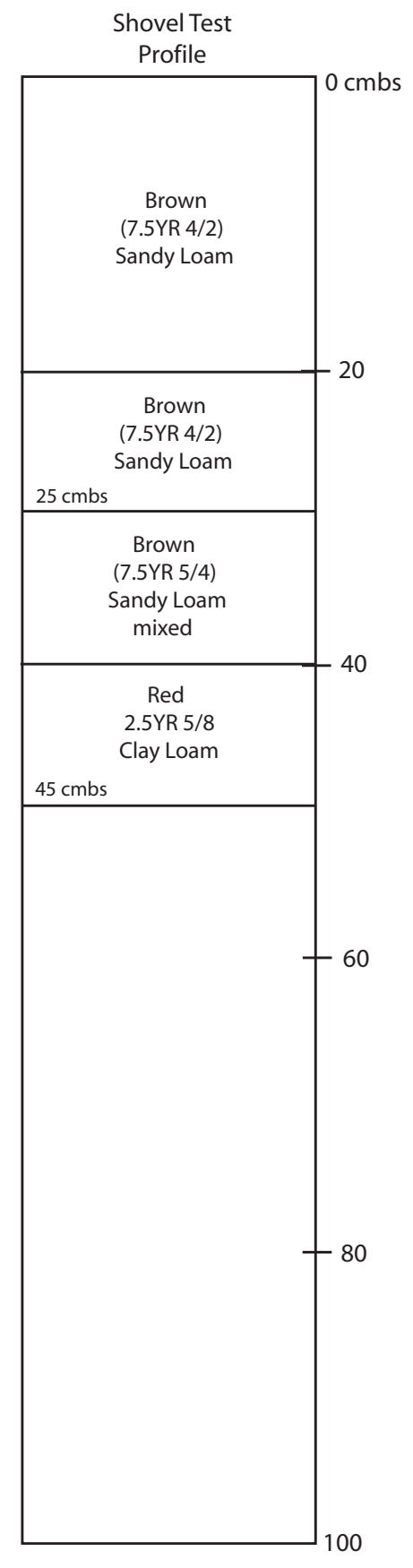

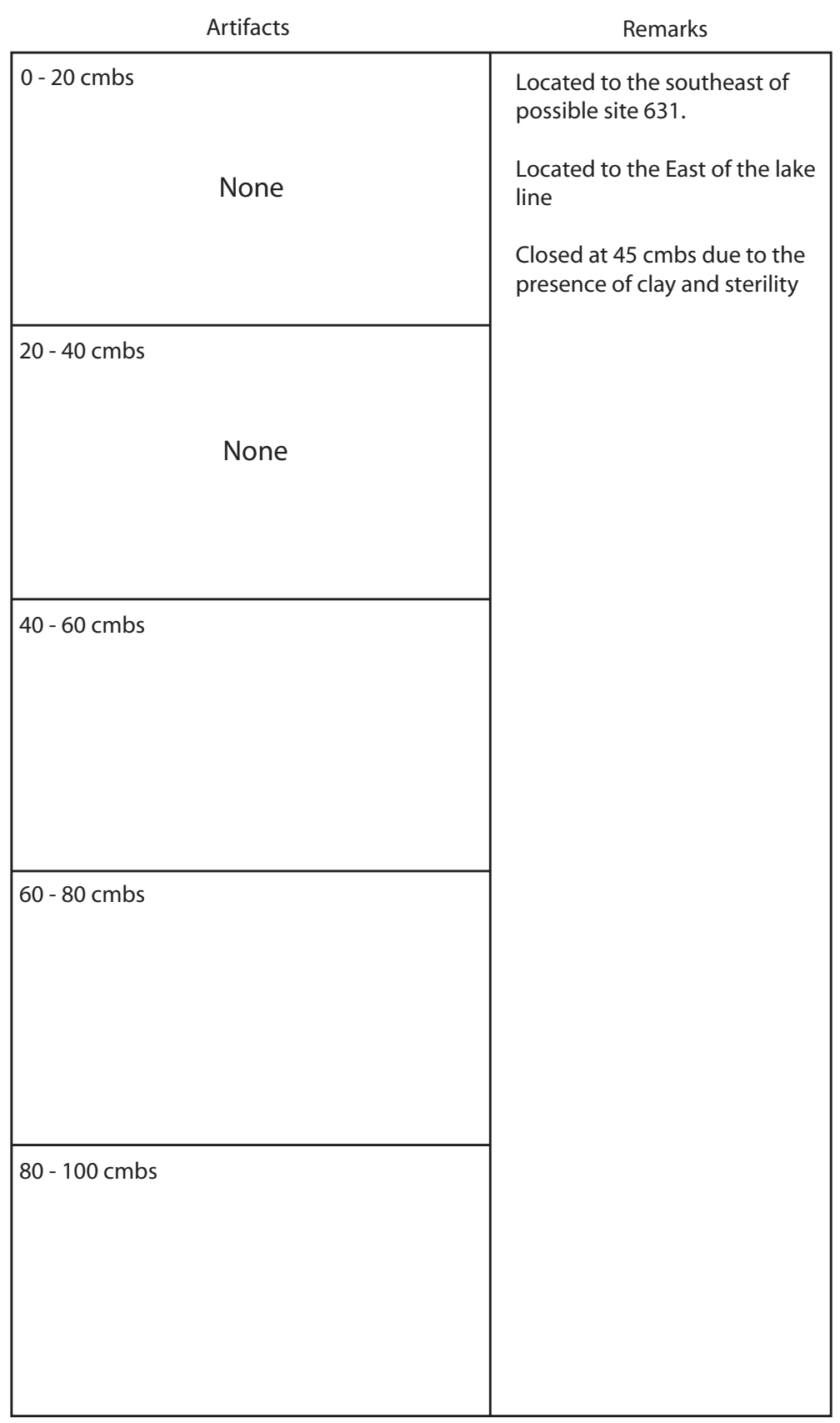


Fairfield Lake State Park - TPWD

Shovel Test No. 109

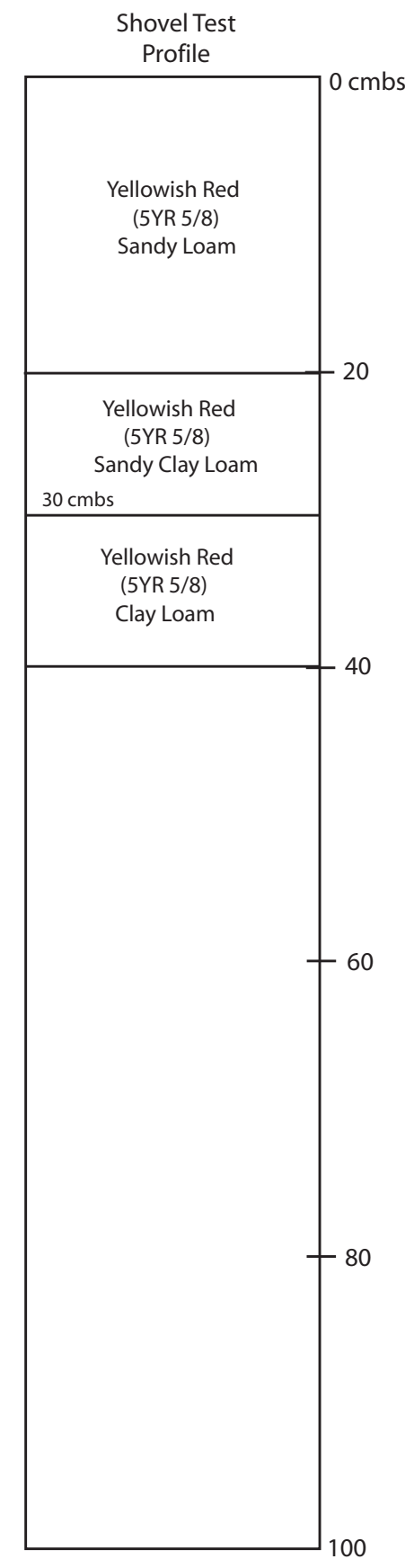

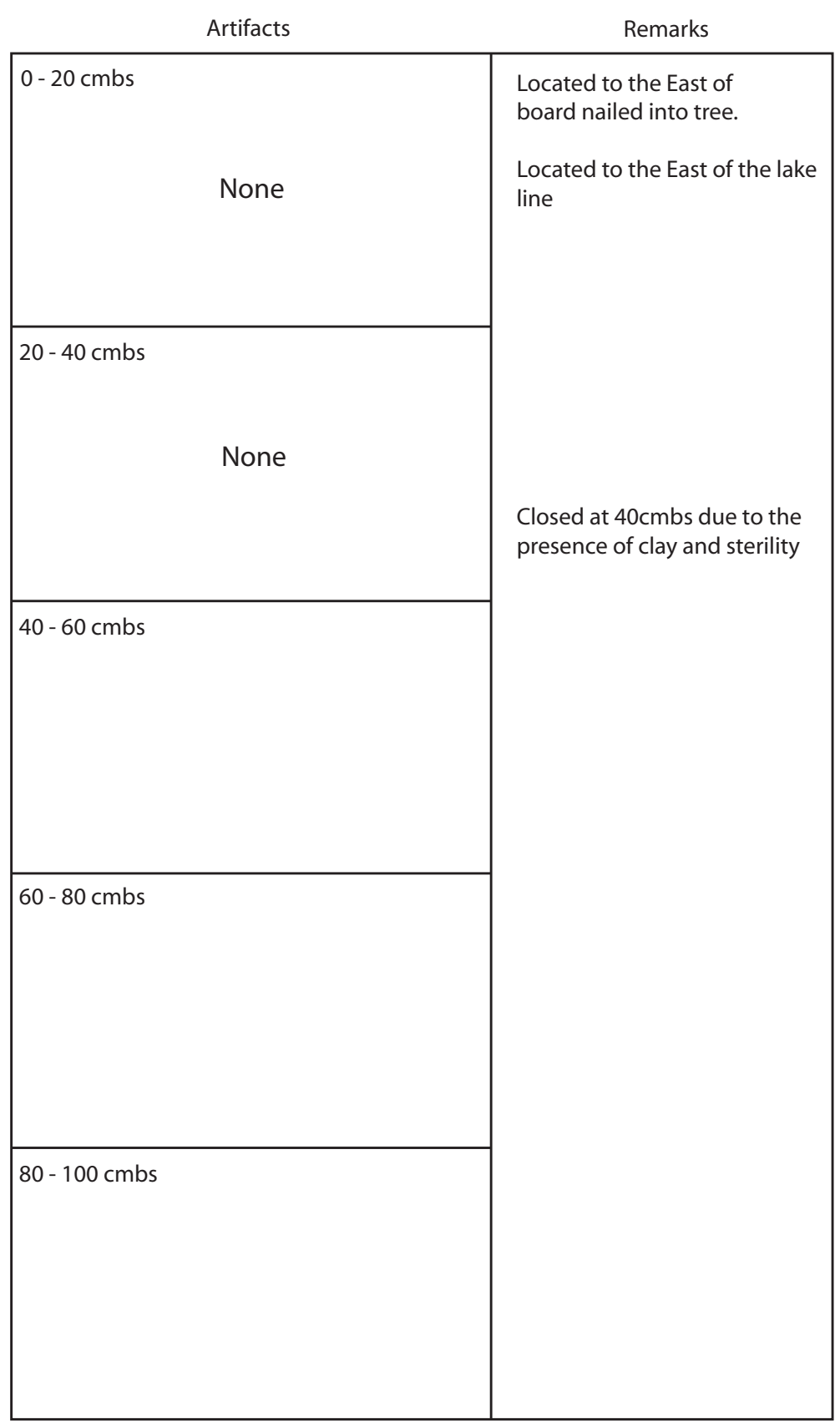


Fairfield Lake State Park - TPWD

Shovel Test No. 114

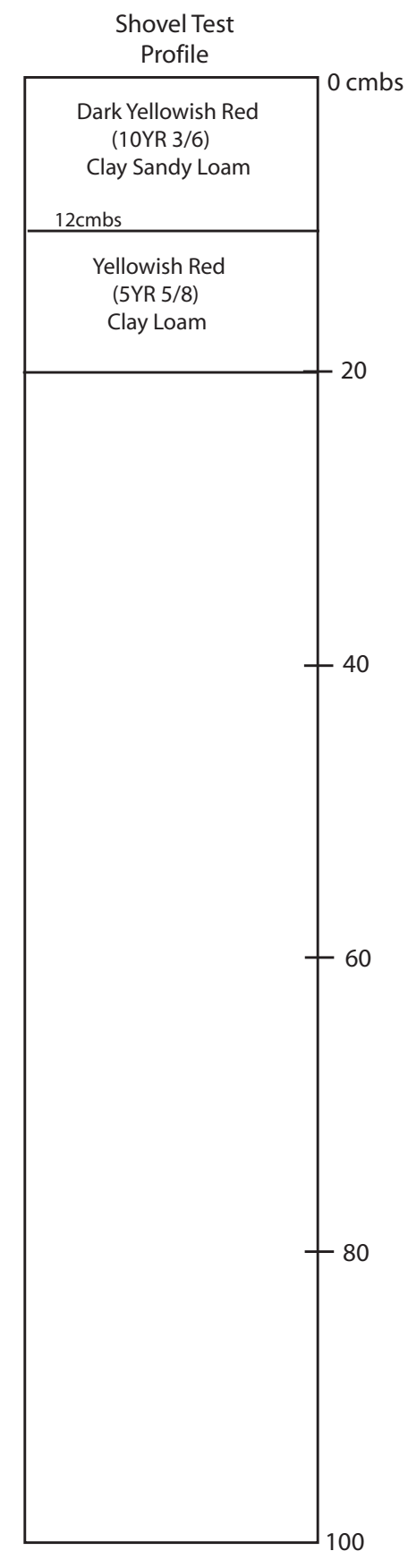

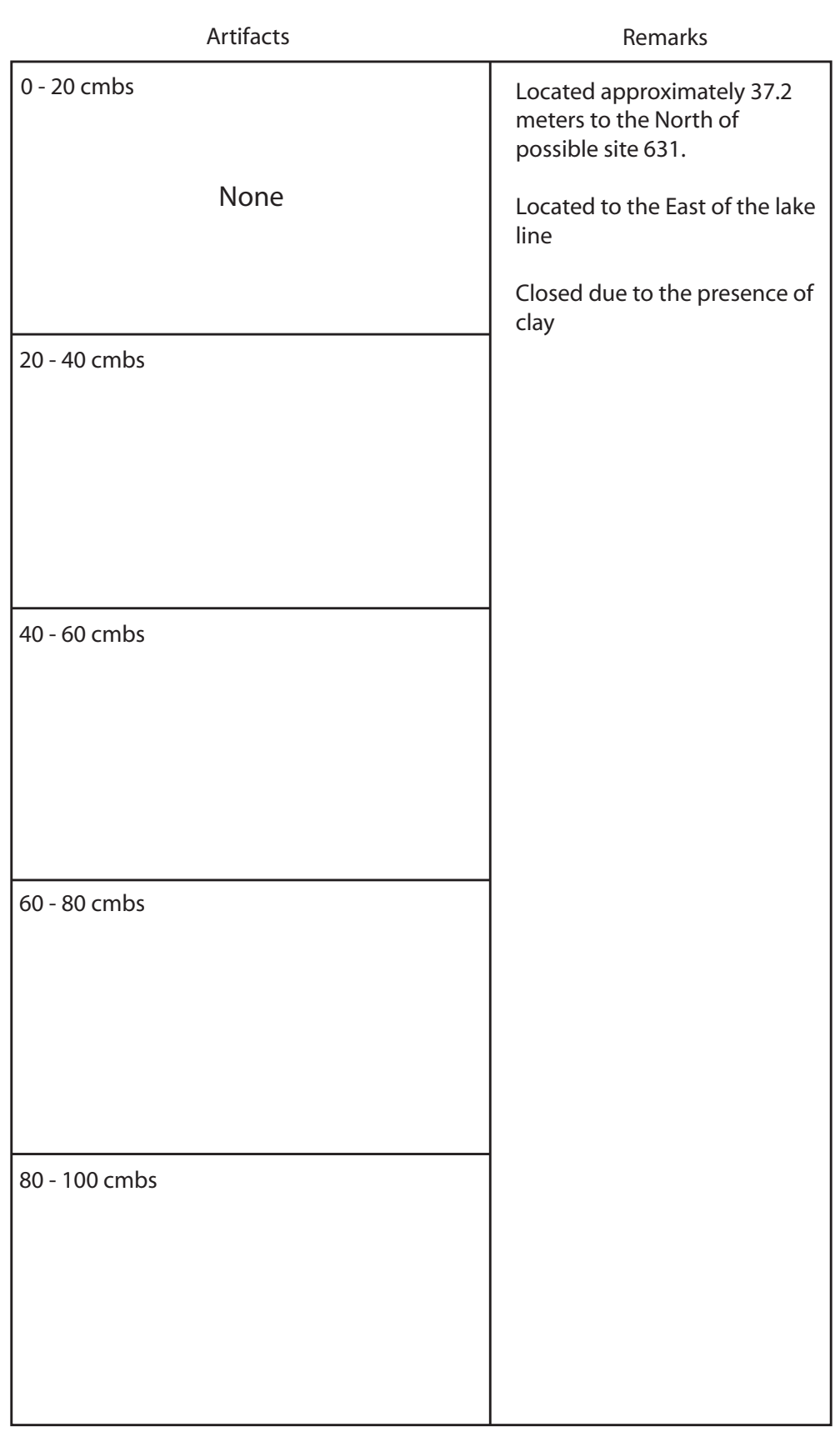


Fairfield Lake State Park - TPWD

Shovel Test No. 118

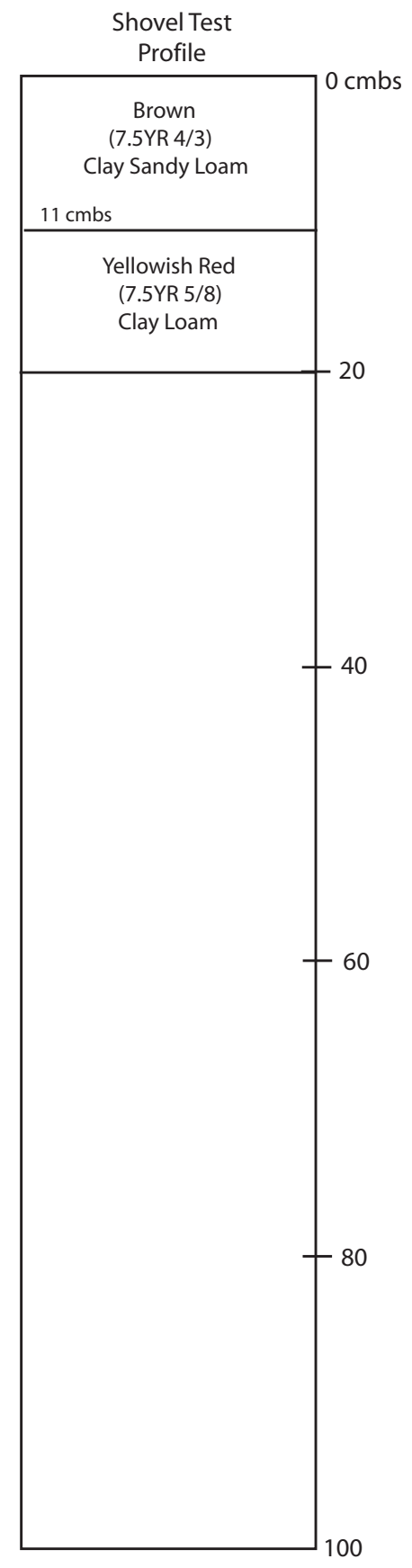

\begin{tabular}{|c|c|}
\hline Artifacts & Remarks \\
\hline $0-20 \mathrm{cmbs}$ & $\begin{array}{l}\text { Located to the South of } \\
\text { possible site } 631 . \\
\text { Located to the East of the lake } \\
\text { line } \\
\text { Closed at } 20 \mathrm{cmbs} \text { due to the } \\
\text { presence of clay and sterility }\end{array}$ \\
\hline $20-40 \mathrm{cmbs}$ & \\
\hline $40-60 \mathrm{cmbs}$ & \\
\hline $60-80 \mathrm{cmbs}$ & \\
\hline $80-100 \mathrm{cmbs}$ & \\
\hline
\end{tabular}




\section{Fairfield Lake State Park - TPWD \\ Shovel Test No. 179}

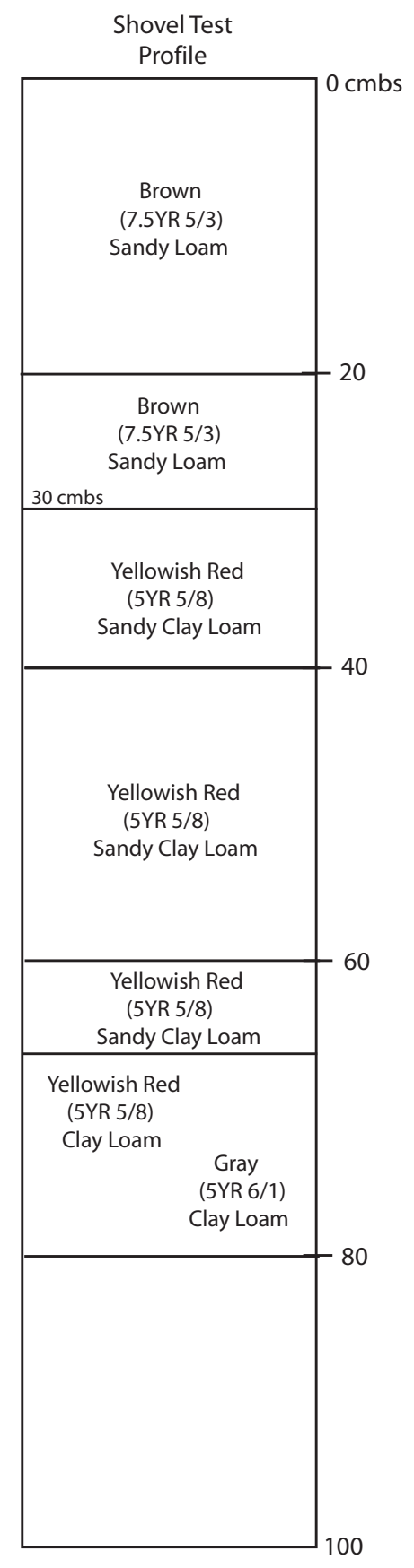

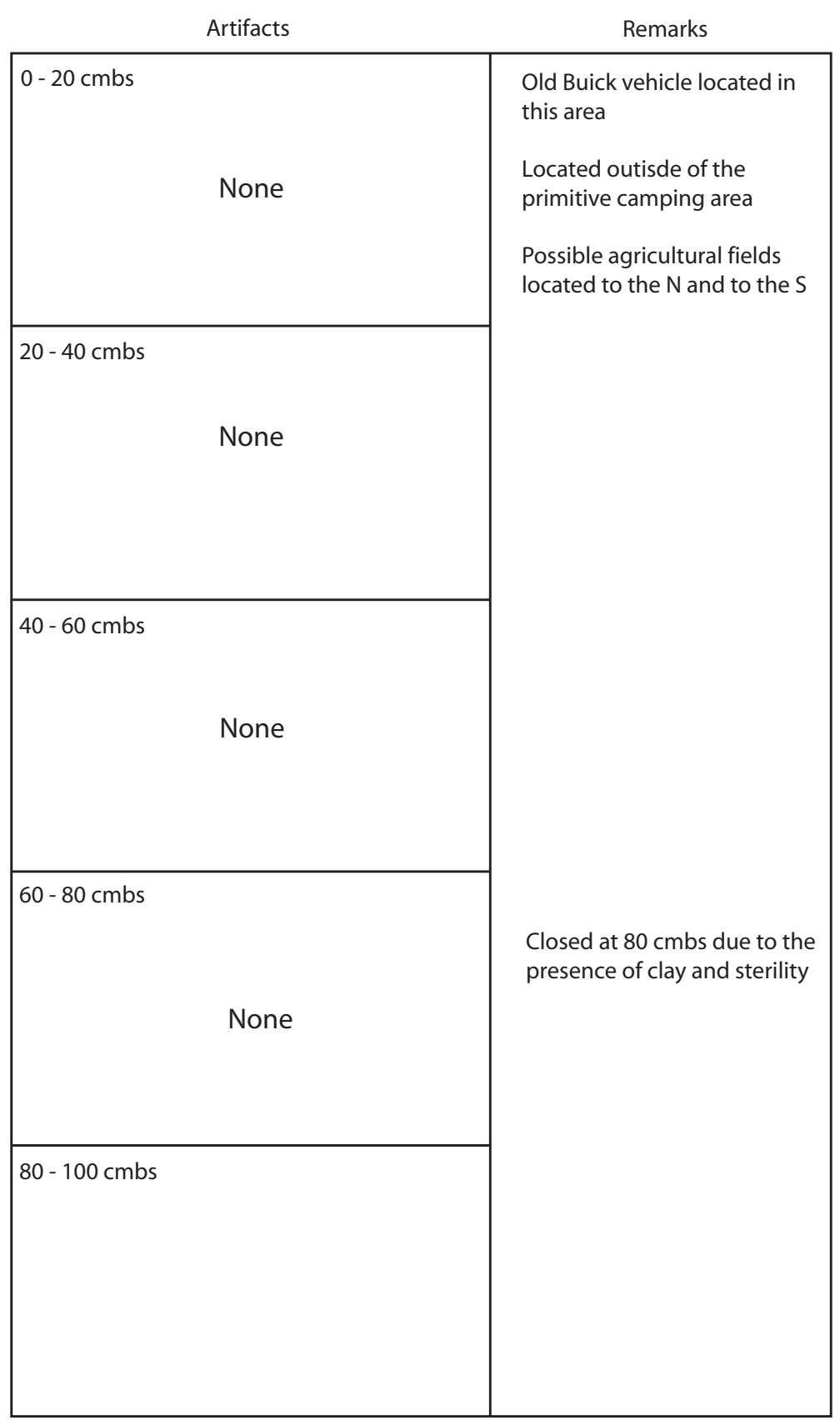




\section{Fairfield Lake State Park - TPWD \\ Shovel Test No. 204}

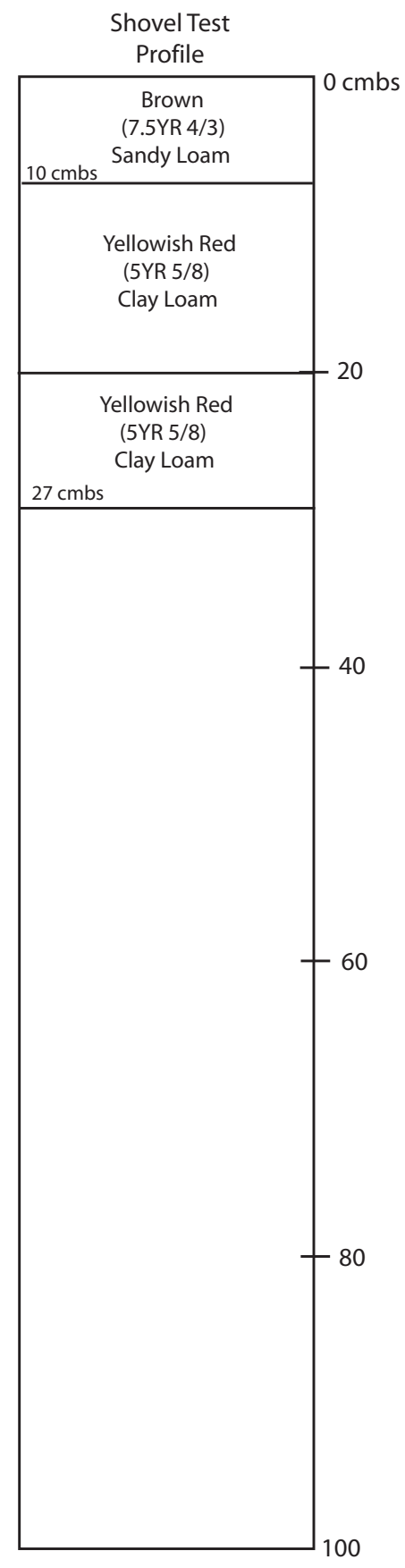

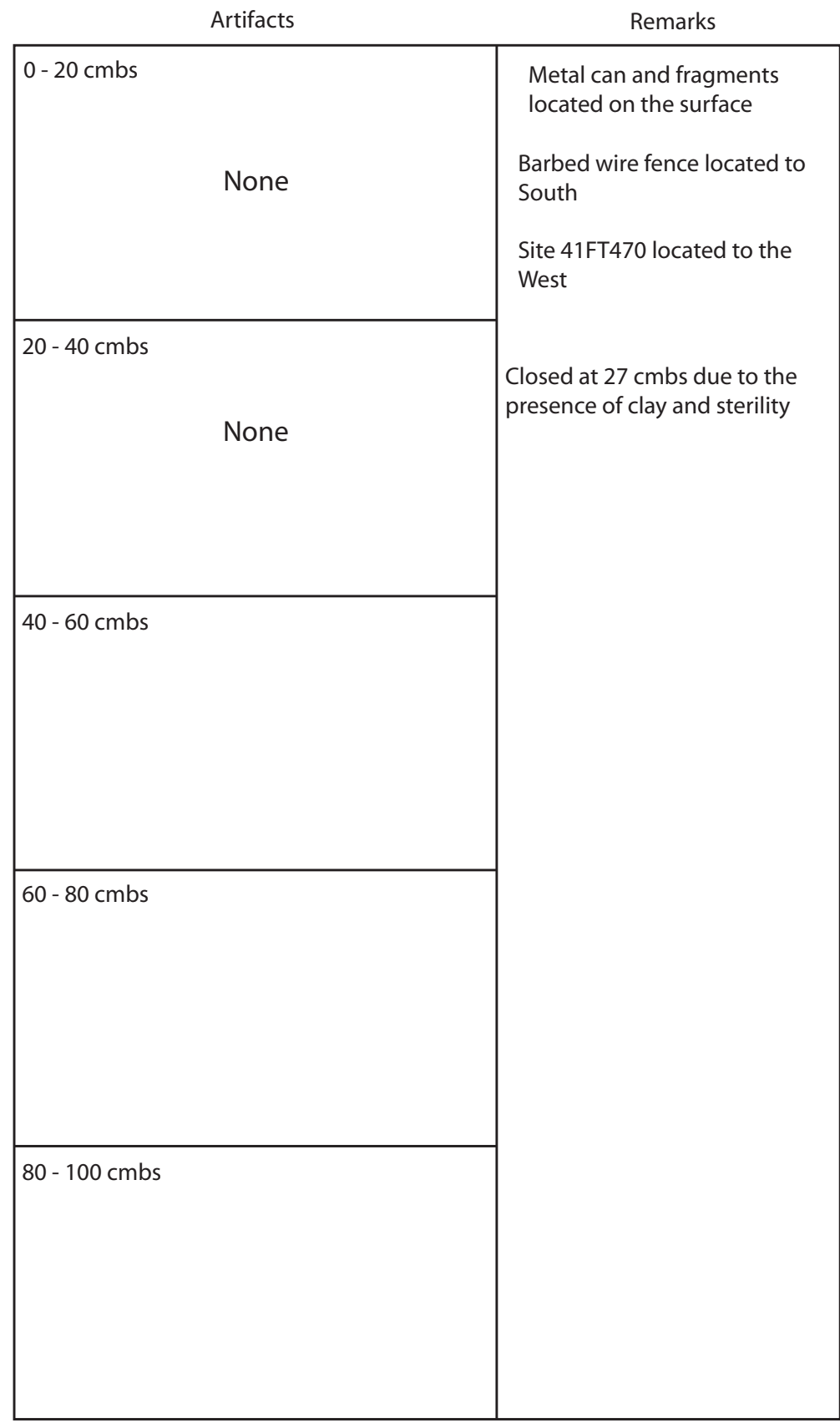


Fairfield Lake State Park - TPWD

Shovel Test No. 211

Shovel Test

Profile

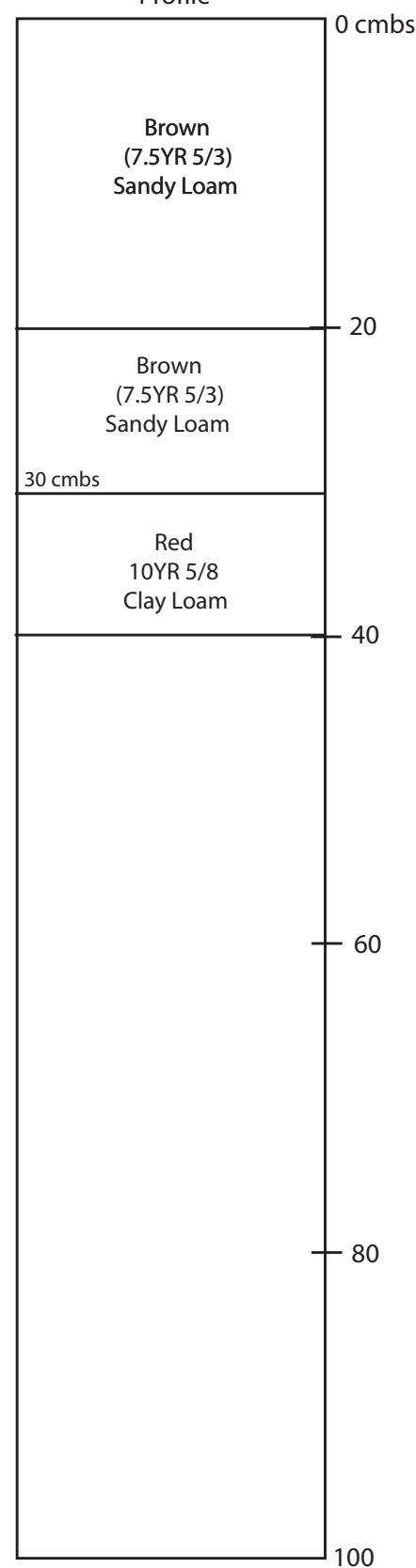

Artifacts

Remarks

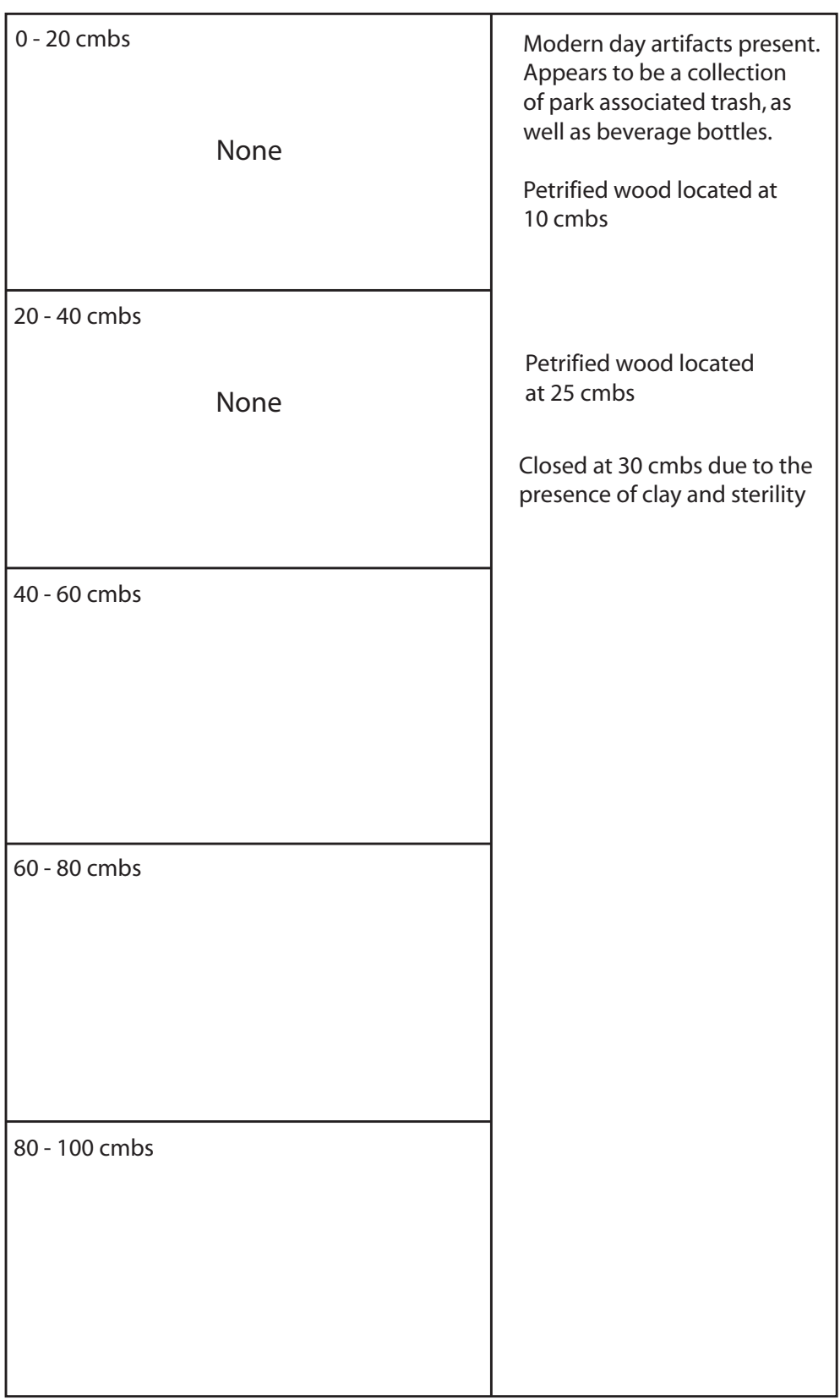


Fairfield Lake State Park - TPWD

Shovel Test No. 215

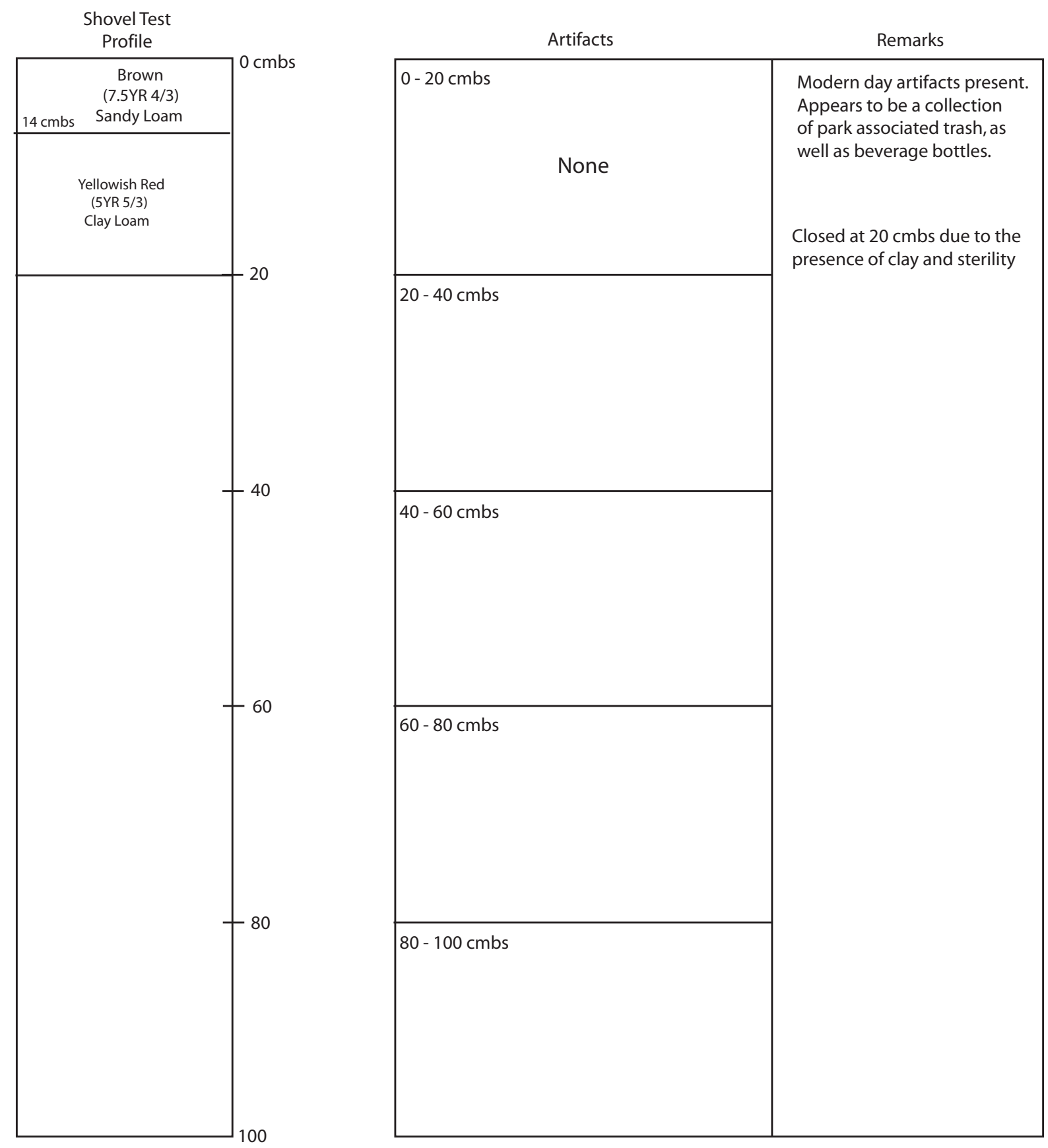




\section{Appendix B}

Sites, their components, and assigned management priority levels.

\begin{tabular}{|c|c|c|c|c|}
\hline \multirow[b]{2}{*}{ Site Trinomia } & \multirow[b]{2}{*}{1 Type } & \multicolumn{2}{|l|}{ Component Age } & \multirow{2}{*}{$\begin{array}{l}\text { Management } \\
\text { Priority (Level)/ } \\
\text { NHPA Eligibility }\end{array}$} \\
\hline & & Prehistoric & Historic & \\
\hline 41FT279 & Historic Homestead & & $\begin{array}{l}\text { Late-19th to } \\
\text { Early 20th } \\
\text { Century }\end{array}$ & $\begin{array}{l}\text { Moderate to } \\
\text { High (Level } \\
\text { 2)/Unknown }\end{array}$ \\
\hline $41 \mathrm{FT} 280$ & Historic Structure & & 19th Century & $\begin{array}{l}\text { High (Level } \\
\text { 1)/Unknown }\end{array}$ \\
\hline 41FT408 & Historic Structure & & $\begin{array}{l}\text { Late-19th to } \\
\text { 20th Century }\end{array}$ & $\begin{array}{l}\text { High (Level } \\
\text { 1)/Unknown }\end{array}$ \\
\hline 41FT409 & Historic Dump & & $\begin{array}{l}\text { Late-19th to } \\
\text { 20th Century }\end{array}$ & $\begin{array}{l}\text { High (Level } \\
\text { 1)/Unknown }\end{array}$ \\
\hline 41FT463 & $\begin{array}{l}\text { Prehistoric Lithic Scat- } \\
\text { ter }\end{array}$ & Unknown & & $\begin{array}{l}\text { Moderate to Low } \\
(\text { Level 3)/Un- } \\
\text { known }\end{array}$ \\
\hline $41 \mathrm{FT} 464$ & Prehistoric Campsite & $\begin{array}{l}\text { Archaic/Late Prehis- } \\
\text { toric }\end{array}$ & & $\begin{array}{l}\text { Moderate to } \\
\text { High (Level } \\
\text { 2)/Unknown }\end{array}$ \\
\hline 41FT465 & $\begin{array}{l}\text { Prehistoric Lithic Scat- } \\
\text { ter }\end{array}$ & $\begin{array}{l}\text { Middle/Transitional } \\
\text { Archaic }\end{array}$ & & $\begin{array}{l}\text { Moderate to } \\
\text { High (Level } \\
\text { 2)/Unknown }\end{array}$ \\
\hline 41FT466 & $\begin{array}{l}\text { Scatter of Prehistoric } \\
\text { and Historic Artifacts }\end{array}$ & Unknown & $\begin{array}{l}\text { Early 20th } \\
\text { Century }\end{array}$ & $\begin{array}{l}\text { Moderate to } \\
\text { High (Level } \\
\text { 2)/Unknown }\end{array}$ \\
\hline 41FT467 & $\begin{array}{l}\text { Prehistoric Lithic Scat- } \\
\text { ter }\end{array}$ & Unknown & & $\begin{array}{l}\text { Moderate to } \\
\text { High (Level } \\
\text { 2)/Unknown }\end{array}$ \\
\hline 41FT468 & $\begin{array}{l}\text { Scatter of Prehistoric } \\
\text { and Historic Artifacts }\end{array}$ & Unknown & 19th Century & $\begin{array}{l}\text { Moderate to } \\
\text { High (Level } \\
\text { 2)/Unknown }\end{array}$ \\
\hline 41FT469 & Historic Dump & & $\begin{array}{l}\text { Early- to } \\
\text { Mid-20th } \\
\text { Century }\end{array}$ & $\begin{array}{l}\text { Moderate to Low } \\
(\text { Level 3)/Un- } \\
\text { known }\end{array}$ \\
\hline
\end{tabular}




\begin{tabular}{|c|c|c|c|c|}
\hline $41 \mathrm{FT} 470$ & Historic Structure & & \begin{tabular}{|l|} 
Early- to \\
Mid-20th \\
Century \\
\end{tabular} & $\begin{array}{l}\text { High (Level } \\
\text { 1)/Unknown } \\
\end{array}$ \\
\hline 41FT471 & $\begin{array}{l}\text { Prehistoric Lithic Scat- } \\
\text { ter (Isolated Find) }\end{array}$ & Unknown & & $\begin{array}{l}\text { Moderate to Low } \\
\text { (Level 3)/Ineli- } \\
\text { gible }\end{array}$ \\
\hline $41 \mathrm{FT} 472$ & $\begin{array}{l}\text { Prehistoric Lithic Scat- } \\
\text { ter/Historic Dump }\end{array}$ & Unknown & $\begin{array}{l}\text { Late-19th to } \\
\text { Early-20th } \\
\text { Century }\end{array}$ & $\begin{array}{l}\text { Low (Level 4)/ } \\
\text { Ineligible }\end{array}$ \\
\hline $41 \mathrm{FT} 473$ & $\begin{array}{l}\text { Prehistoric Lithic Scat- } \\
\text { ter }\end{array}$ & Unknown & & $\begin{array}{l}\text { Moderate to } \\
\text { High (Level } \\
\text { 2)/Unkown }\end{array}$ \\
\hline $41 \mathrm{FT} 474$ & Historic Special-Use & & $\begin{array}{l}\text { Early- to } \\
\text { Mid-20th } \\
\text { Century } \\
\end{array}$ & $\begin{array}{l}\text { Moderate to } \\
\text { High (Level } \\
\text { 2)/Unknown }\end{array}$ \\
\hline $41 \mathrm{FT} 475$ & Historic Dump & & 20th Century & $\begin{array}{l}\text { Moderate to Low } \\
\text { (Level 3)/Un- } \\
\text { known }\end{array}$ \\
\hline $41 \mathrm{FT} 476$ & $\begin{array}{l}\text { Prehistoric Lithic Scat- } \\
\text { ter }\end{array}$ & Unknown & & $\begin{array}{l}\text { Moderate to Low } \\
\text { (Level 3)/Un- } \\
\text { known }\end{array}$ \\
\hline $41 \mathrm{FT} 477$ & $\begin{array}{l}\text { Possible Historic Struc- } \\
\text { ture }\end{array}$ & & $\begin{array}{l}\text { Early-20th } \\
\text { Century }\end{array}$ & $\begin{array}{l}\text { Moderate to } \\
\text { High (Level } \\
\text { 2)/Unknown }\end{array}$ \\
\hline 41FT478 & $\begin{array}{l}\text { Prehistoric Lithic Scat- } \\
\text { ter (Isolated Find) }\end{array}$ & Unknown & & $\begin{array}{l}\text { Moderate to Low } \\
\text { (Level 3)/Un- } \\
\text { known }\end{array}$ \\
\hline 41FT479 & $\begin{array}{l}\text { Prehistoric Lithic Scat- } \\
\text { ter }\end{array}$ & Unknown & & $\begin{array}{l}\text { Moderate to Low } \\
\text { (Level 3)/Un- } \\
\text { known }\end{array}$ \\
\hline 41FT480 & $\begin{array}{l}\text { Prehistoric Lithic Scat- } \\
\text { ter }\end{array}$ & Unknown & & $\begin{array}{l}\text { Moderate to Low } \\
\text { (Level 3)/Un- } \\
\text { kown }\end{array}$ \\
\hline 41FT481 & $\begin{array}{l}\text { Possible Historic Struc- } \\
\text { ture }\end{array}$ & & $\begin{array}{l}\text { Late-19th to } \\
\text { Early-20th } \\
\text { Century }\end{array}$ & $\begin{array}{l}\text { High (Level } \\
\text { 1)/Unknown }\end{array}$ \\
\hline 41FT482 & Historic Structure & & $\begin{array}{l}\text { Early- to } \\
\text { Mid-20th } \\
\text { Century }\end{array}$ & $\begin{array}{l}\text { Moderate to } \\
\text { High (Level } \\
\text { 2)/Unknown }\end{array}$ \\
\hline $41 \mathrm{FT} 483$ & Prehistoric Campsite & $\begin{array}{l}\text { Archaic/Late Prehis- } \\
\text { toric }\end{array}$ & & $\begin{array}{l}\text { Moderate to } \\
\text { High (Level } \\
\text { 2)/Unknown }\end{array}$ \\
\hline
\end{tabular}




\begin{tabular}{|c|c|c|c|c|}
\hline $41 \mathrm{FT} 484$ & Prehistoric Campsite & Unknown & & $\begin{array}{l}\text { Moderate to Low } \\
(\text { Level 3)/Un- } \\
\text { known }\end{array}$ \\
\hline $41 \mathrm{FT} 485$ & $\begin{array}{l}\text { Possible Historic Struc- } \\
\text { ture }\end{array}$ & & $\begin{array}{l}\text { Late-19th to } \\
\text { Early-20th } \\
\text { Century }\end{array}$ & $\begin{array}{l}\text { Moderate to } \\
\text { High (Level } \\
\text { 2)/Unknown }\end{array}$ \\
\hline 41FT486 & $\begin{array}{l}\text { Historic Homestead/ } \\
\text { Farmstead }\end{array}$ & & 20th Century & $\begin{array}{l}\text { Moderate to Low } \\
(\text { Level 3)/Un- } \\
\text { known }\end{array}$ \\
\hline 41FT487 & $\begin{array}{l}\text { Possible Historic Struc- } \\
\text { ture }\end{array}$ & & $\begin{array}{l}\text { Late-19th to } \\
\text { Early-20th } \\
\text { Century }\end{array}$ & $\begin{array}{l}\text { Low (Level 4)/ } \\
\text { Ineligible }\end{array}$ \\
\hline $41 \mathrm{FT} 488$ & $\begin{array}{l}\text { Prehistoric Lithic Scat- } \\
\text { ter }\end{array}$ & Unknown & & $\begin{array}{l}\text { Moderate to Low } \\
(\text { Level 3)/Un- } \\
\text { known }\end{array}$ \\
\hline $41 \mathrm{FT} 496$ & $\begin{array}{l}\text { Prehistoric Lithic Scat- } \\
\text { ter (Isolated Find) }\end{array}$ & Unknown & & $\begin{array}{l}\text { Low (Level 4)/ } \\
\text { Ineligible }\end{array}$ \\
\hline $41 \mathrm{FT} 497$ & Unknown & Unknown & Unknown & $\begin{array}{l}\text { Low (Level 4)/ } \\
\text { Ineligible }\end{array}$ \\
\hline 41FT498 & $\begin{array}{l}\text { Prehistoric Lithic Scat- } \\
\text { ter (Isolated Find) }\end{array}$ & Unknown & & $\begin{array}{l}\text { Low (Level 4)/ } \\
\text { Ineligible }\end{array}$ \\
\hline 41FT499 & Unknown Historic & & Unknown & $\begin{array}{l}\text { Low (Level 4)/ } \\
\text { Ineligible }\end{array}$ \\
\hline 41FT630 & Historic Cemetery & & 19th Century & $\begin{array}{l}\text { High (Level } \\
\text { 1)/Eligible }\end{array}$ \\
\hline
\end{tabular}


